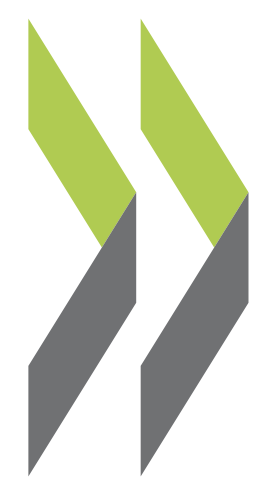

OECD Economics Department Working Papers No. 1404

\title{
Improving the efficiency and outcomes of the Slovak health-care system
}

Claude Giorno,

\section{Kristina Londáková}

https://dx.doi.org/10.1787/f2b496cd-en 
Organisation de Coopération et de Développement Économiques

Organisation for Economic Co-operation and Development

07-Aug-2017

ECONOMICS DEPARTMENT

English - Or. English

Cancels \& replaces the same document of 13 July 2017

IMPROVING THE EFFICIENCY AND OUTCOMES OF THE SLOVAK HEALTH-CARE SYSTEM

ECONOMICS DEPARTMENT WORKING PAPERS No. 1404

By Claude Giorno and Kristina Londáková

OECD Working Papers should not be reported as representing the official views of the OECD or of its member countries. The opinions expressed and arguments employed are those of the author(s).

Authorised for publication by Alvaro Pereira, Director, Country Studies Branch, Economics Department.

All Economics Department Working Papers are available at www.oecd.org/eco/workingpapers

JT03417875

Complete document available on OLIS in its original format

This document, as well as any data and map included herein, are without prejudice to the status of or sovereignty over any territory, to the delimitation of international frontiers and boundaries and to the name of any territory, city or area. 
OECD Working Papers should not be reported as representing the official views of the OECD or of its member countries. The opinions expressed and arguments employed are those of the author(s).

Working Papers describe preliminary results or research in progress by the author(s) and are published to stimulate discussion on a broad range of issues on which the OECD works.

Comments on Working Papers are welcomed, and may be sent to OECD Economics Department, 2 rue André-Pascal, 75775 Paris Cedex 16, France, or by e-mail to eco.contact@oecd.org.

All Economics Department Working Papers are available at. www.oecd.org/eco/workingpapers.

This document and any map included herein are without prejudice to the status of or sovereignty over any territory, to the delimitation of international frontiers and boundaries and to the name of any territory, city or area.

The statistical data for Israel are supplied by and under the responsibility of the relevant Israeli authorities. The use of such data by the OECD is without prejudice to the status of the Golan Heights, East Jerusalem and Israeli settlements in the West Bank under the terms of international law.

\section{(C) OECD (2017)}

You can copy, download or print OECD content for your own use, and you can include excerpts from OECD publications, databases and multimedia products in your own documents, presentations, blogs, websites and teaching materials, provided that suitable acknowledgment of OECD as source and copyright owner is given. All requests for commercial use and translation rights should be submitted to rights@oecd.org 
ECO/WKP(2017)36

\section{ABSTRACT/RÉSUMÉ \\ Improving the efficiency and outcomes of the Slovak health-care system}

Despite improvements over the past few decades, Slovak health outcomes remains poor compared with most other OECD countries, even after controlling for differences in per capita income and other social, cultural and lifestyle factors. Disparities in access to care and health outcomes between the Roma and the rest of the population are large. Moreover, the health-care system is a source of general discontent because of high out-ofpocket payments, long waiting lists for some medical services and widely perceived mismanagement of public health-care spending. Health-care spending is currently about in line with the country's standard of living. However, improving the efficiency of this sector is key: meeting the rising demand for medical services in the coming decades while containing government spending to maintain sound public finances will be challenging. The most pressing issues to be addressed concern: enhancing the efficiency and quality of primary care; addressing the shortage of nurses and replacing the large number of retiring physicians; modernising hospital infrastructure and management; further tightening control over pharmaceutical and other ancillary spending; developing a comprehensive strategy for long-term care; promoting better care access for the Roma population; and improving lifestyles through well-designed public health and disease-prevention policies.

This Working Paper relates to the 2017 OECD Economic Survey of the Slovak Republic (www.oecd.org/eco/surveys/economic-survey-slovak-republic.htm).

JEL codes: I10, I11, I 13, I14, I18

Keywords: Health care system, health policy, hospital, primary health care, pharmaceutical expenditure, generic drugs, medical prevention, co-payment, referral system, prescription system, excise tax, health insurance funds, National health system, medical demography, general practitioners, long-term care

$* * * * * * * * * *$

\section{Améliorer l'efficience et les résultats du système slovaque de soins de santé}

Malgré les progrès intervenus au cours des dernières décennies, les résultats de la République slovaque en matière de santé demeurent médiocres comparés à ceux de la plupart des autres pays de l'OCDE, même une fois prises en compte les différences de revenu par habitant et d'autres facteurs sociaux, culturels et liés aux modes de vie. Les disparités entre les Roms et le reste de la population en matière d'accès aux soins et de résultats sanitaires sont considérables. En outre, le système de soins de santé est une source générale de mécontentement, en raison de l'importance du reste à charge que doivent assumer les patients, de la longueur des listes d'attente pour certains services médicaux, et du sentiment largement répandu que les dépenses publiques de soins de santé sont mal gérées. Les dépenses de soins de santé correspondent actuellement peu ou prou au niveau de vie du pays. Néanmoins, il est crucial d'améliorer l'efficience de ce secteur : il ne sera pas aisé de satisfaire la demande croissante de services médicaux au cours des décennies à venir tout en maitrisant les dépenses publiques, pour conserver des finances publiques saines. Les points les plus urgents à traiter consistent à : améliorer l'efficience et la qualité des soins primaires ; remédier à la pénurie de personnel infirmier et remplacer les nombreux médecins partant à la retraite ; moderniser l'infrastructure et la gestion des hôpitaux ; renforcer encore la maitrise des dépenses de produits pharmaceutiques et de services auxiliaires ; élaborer une stratégie globale concernant les soins de longue durée; prendre des mesures pour améliorer l'accès aux soins de la population rom; et améliorer les modes de vie en mettant en œuvre des politiques de santé publique et de prévention des maladies judicieusement conçues.

Ce Document de travail se rapporte à l'Etude économique de l'OCDE de la République slovaque 2017 (www.oecd.org/fr/eco/etudes/etude-economique-republique-slovaque.htm).

Codes JEL: I10, I1 1, I 13, I14, I18

Mots clés : Système de santé, politique de santé, hôpital, soins primaires de santé, dépenses pharmaceutiques, génériques, prévention médicale, co-paiement, système de médecin référent, système de prescription, accises, caisses d'assurance médicales, système national de santé, démographie médicale, médecins généralistes, soins de longue durée 


\section{TABLE OF CONTENTS}

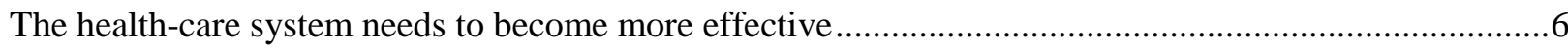

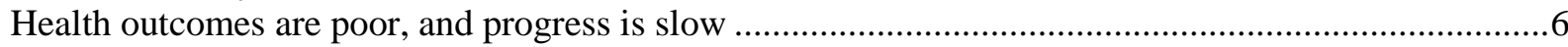

Large health inequalities exist between the Roma and non-Roma population........................................8

The operation of the health-care system is a source of deep discontent..............................................11

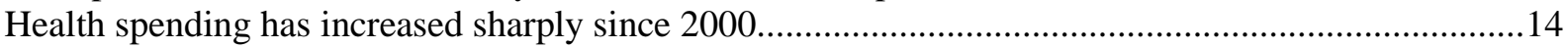

There seems to be significant room for improving the efficiency of the health-care system.................15

A more effective health-care system would have economic and fiscal benefits and promote well-being17

Improving the health-care system will require reforms in several areas .................................................19

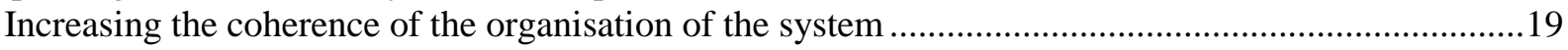

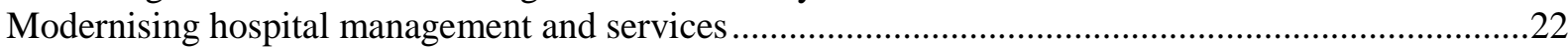

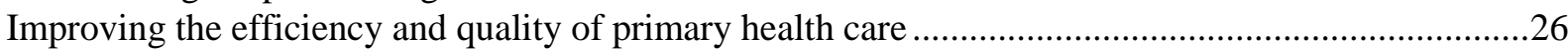

Pursuing efforts to bring down pharmaceutical expenditure and other ancillary health-care spending. 33

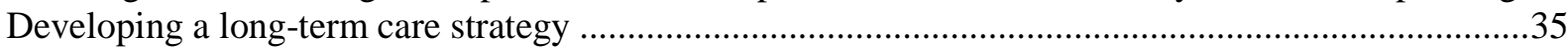

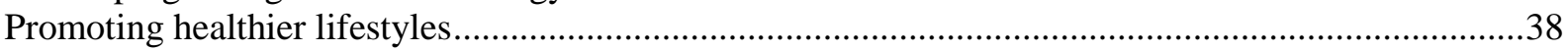

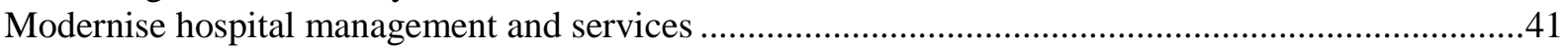

Improve the efficiency and quality of primary health care ................................................................41

Pursue efforts to bring down pharmaceutical expenditure and other ancillary health-care spending ....41

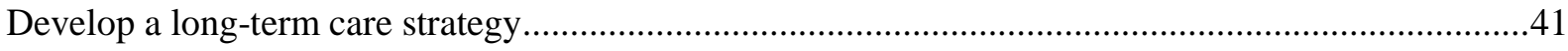

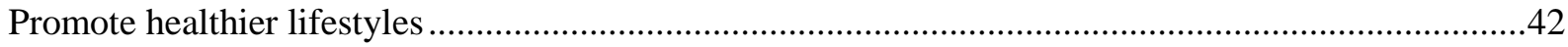

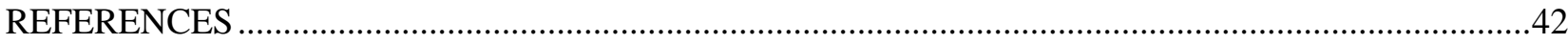

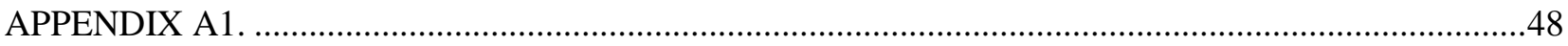

\section{Tables}

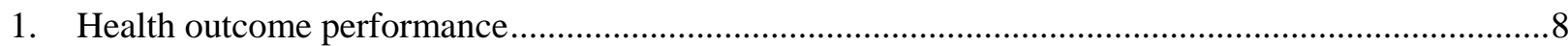

2. Projected increases in public health and long-term care spending by main source, 2010-60.............18

\section{Figures}

Figure 1. Slovak life expectancy at birth is comparatively low even adjusted for per capita

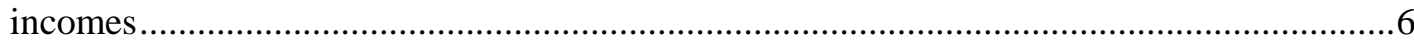

Figure 2. Slovak life expectancy outcomes are relatively poor ..................................................

Figure 3. Selected health indicators of the Roma and non-Roma population ....................................

Figure 4. Regional disparities of infant mortality in OECD countries..............................................10

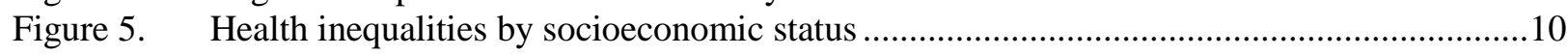

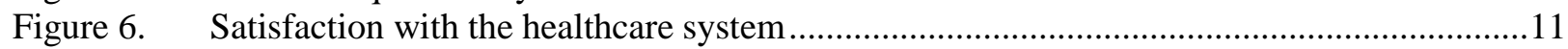

Figure 7. Household out-of-pocket expenditure on health care ................................................12

Figure 8. Perception of corruption in the public healthcare sector...............................................12

Figure 9. Average waiting days for elective surgery ...............................................................13

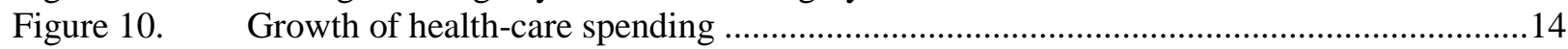

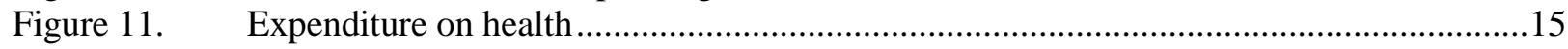

Figure 12. Potential efficiency gains in health care …..................................................................16

Figure 13. Health administrative spending by type of healthcare system.......................................22

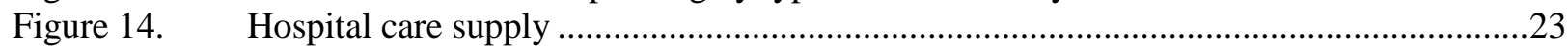

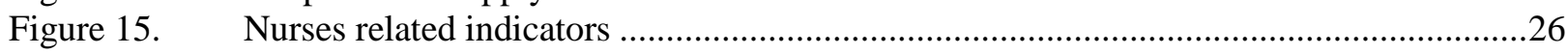

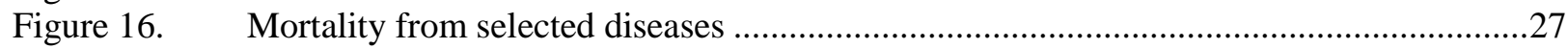




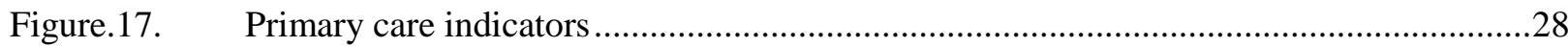

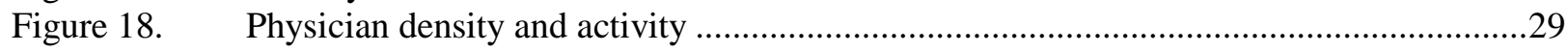

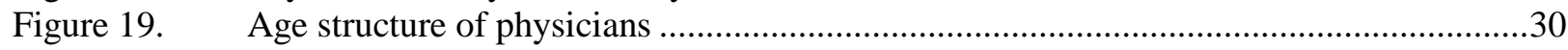

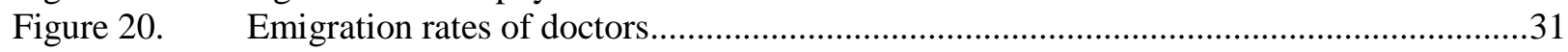

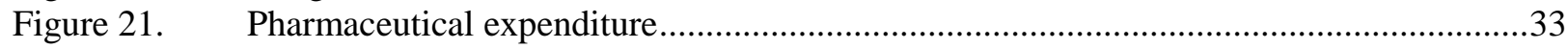

Figure 22. Other medical goods and ancillary health services....................................................34

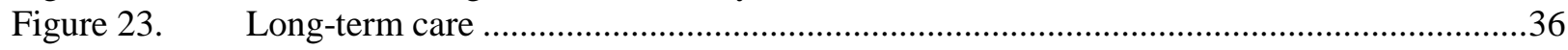

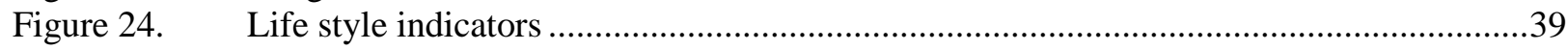

Figure 25. Selected indicators of Roma versus non-Roma living conditions ...................................40

\section{Boxes}

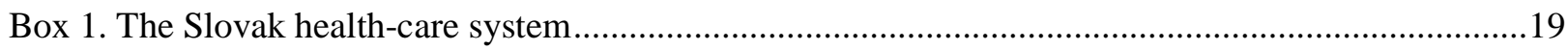

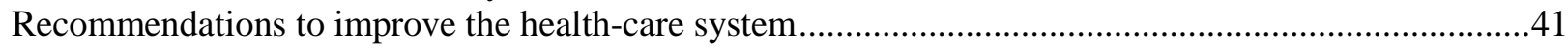




\title{
IMPROVING THE EFFICIENCY AND OUTCOMES OF THE SLOVAK HEALTH-CARE SYSTEM
}

\author{
By Claude Giorno and Kristina Londáková ${ }^{1}$
}

\section{The health-care system needs to become more effective}

\section{Health outcomes are poor, and progress is slow}

The Slovak Republic's health outcomes rank poorly in international comparisons. Life expectancy at birth is shorter than in countries with similar or lower living standards (Figure 1). The same applies to several other health indicators, which ought to be better for a country with the Slovak Republic's GDP per capita. Life expectancy at 65 and health-adjusted life expectancy (i.e. the average number of years that an individual is expected to live in a healthy state) are among the lowest in the OECD. Infant mortality is also high, as is amenable mortality, compared with countries with similar economic development (Figure 2). Moreover, the population's health status remains low compared with most other OECD countries, even after controlling for differences in social, cultural and lifestyle factors (Table 1)

Figure 1. Slovak life expectancy at birth is comparatively low even adjusted for per capita incomes $2014^{1}$

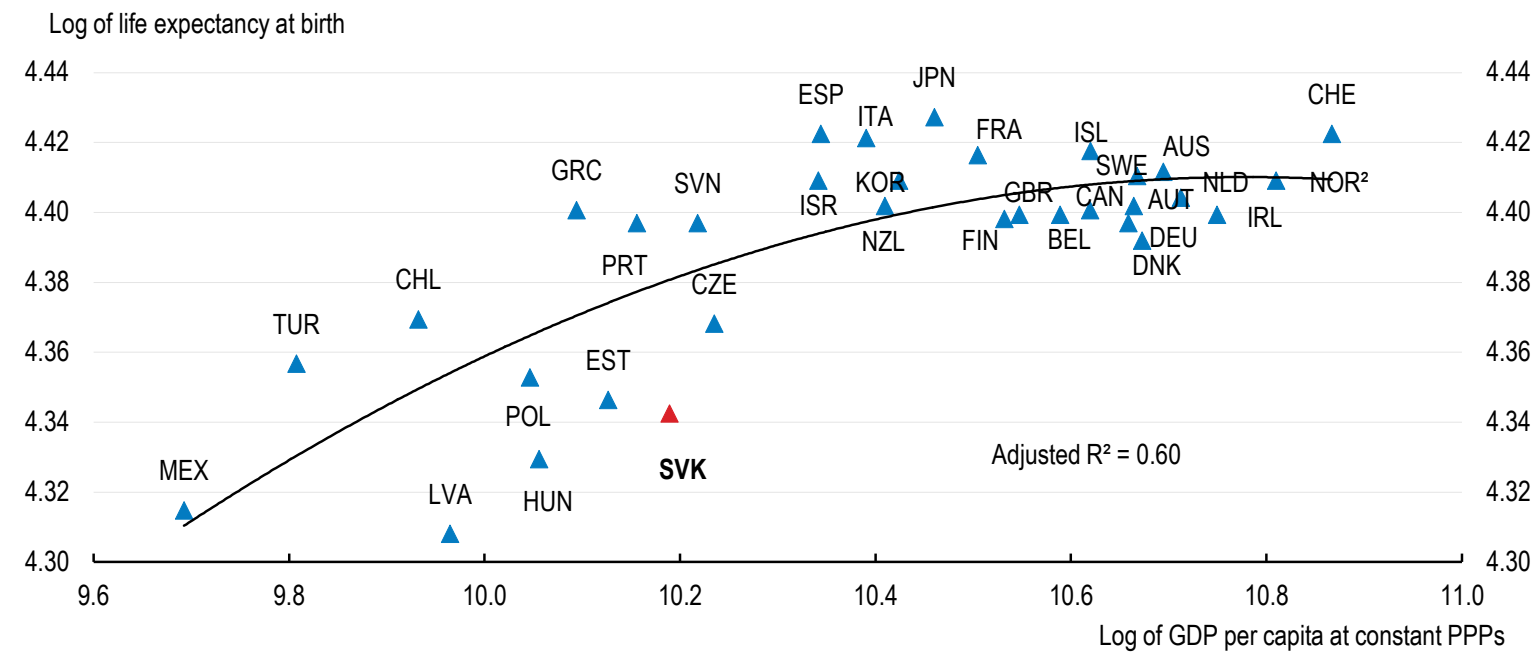

1. Luxembourg and United States are excluded. 2011 for Canada.

2. Mainland GDP for Norway.

Source: OECD (2016), OECD Health Statistics (database), OECD National Accounts Statistics (database) and OECD calculations based on OECD National Accounts Statistics (database).

\footnotetext{
${ }^{1}$ Claude Giorno is a Senior Economist in the Country Studies Branch of the Economics Department of the OECD; e-mail: claude.giorno@oecd.org. Kristina Londáková is Associate Advisor at the Behavioural Insight Team in London. We would like to thank, without implicating, OECD Economics Department colleagues Alvaro Pereira, Bob Ford, Peter Jarrett, Gabriel Machlica, as well as Jens Wilkens (OECD Directorate for Employment and Social Affairs), Michaela Černěnko (Ministry of Health of the Slovak Republic), and Slovak government officials for valuable comments and/or discussions. Special thanks are due to Paula Adamczyk, Béatrice Guérard and Eun Jung Kim (OECD, Economics Department) for excellent statistical assistance and Amelia Godber (OECD, Economics Department) for editorial assistance.
} 
Figure 2. Slovak life expectancy outcomes are relatively poor
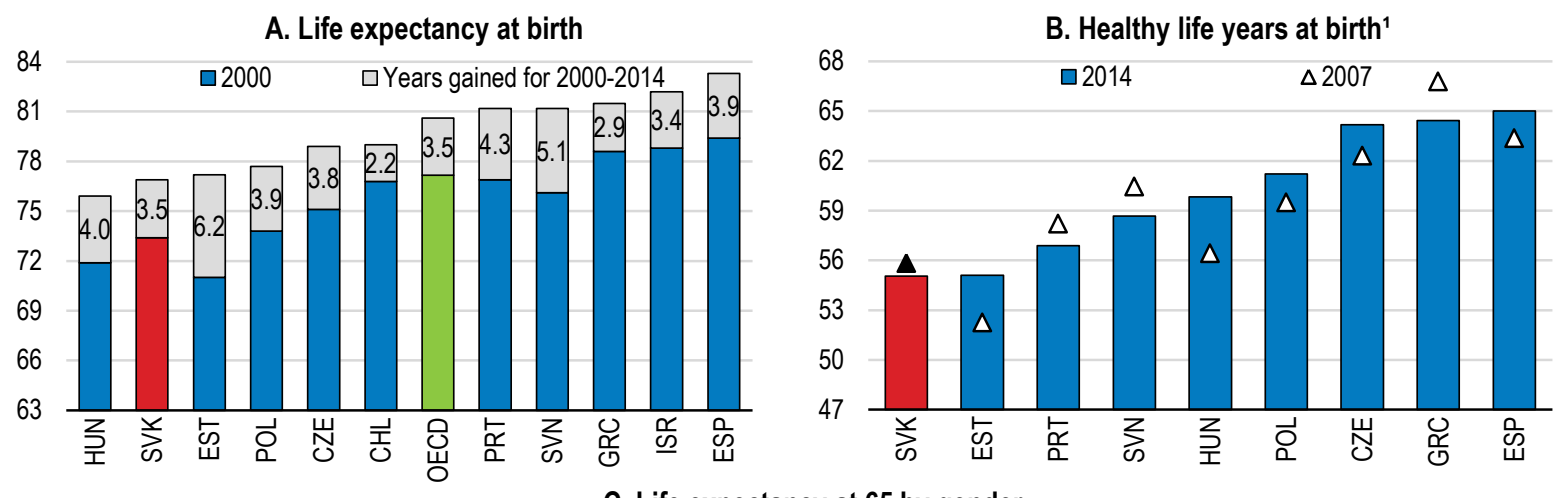

C. Life expectancy at 65 by gender

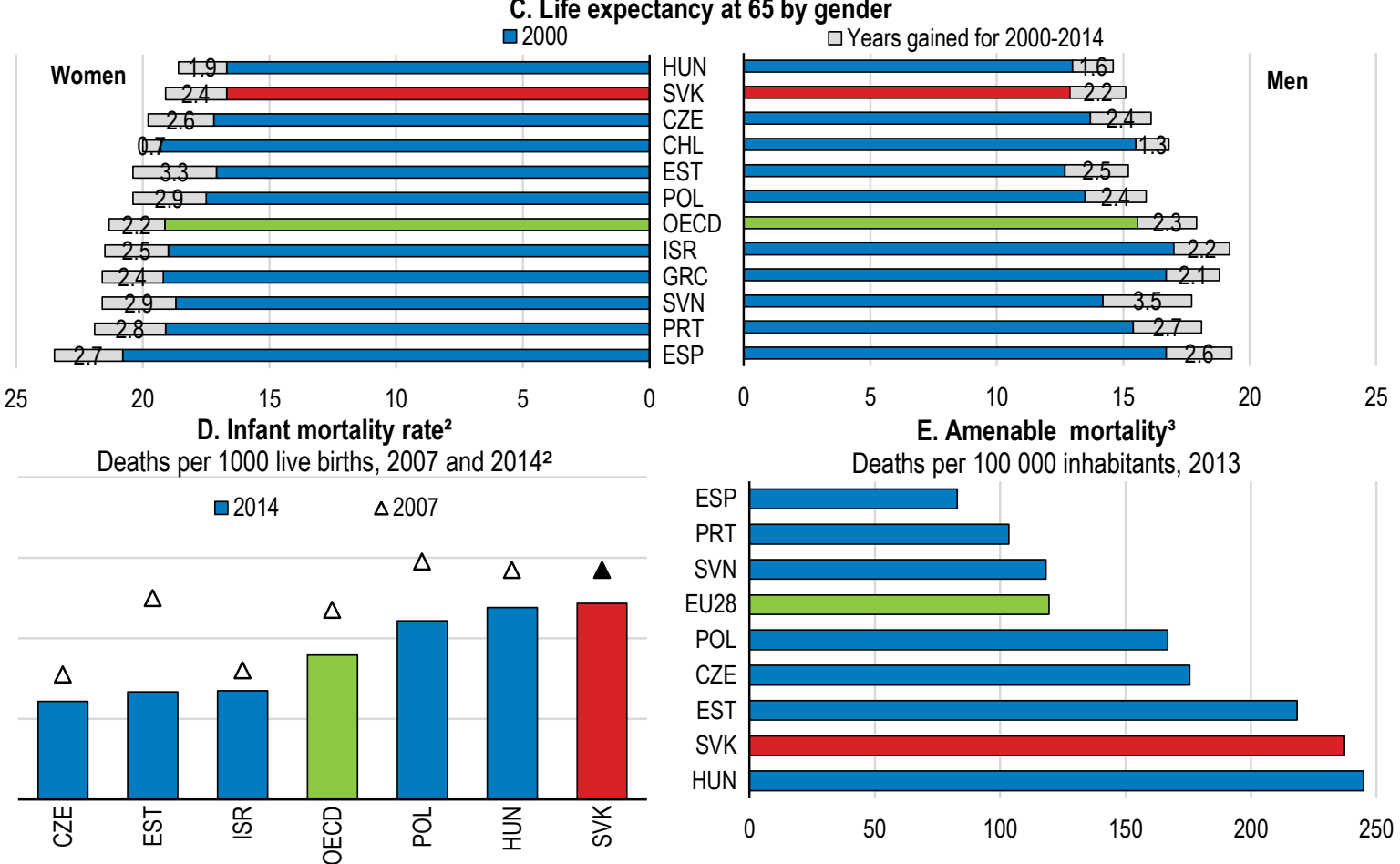

1. Weighted average of data by gender for the population less than one year.

2. Based on the minimum threshold of 22 weeks of gestation period (or 500 grams birthweight). Three-year average (2012-14).

3. Defined as deaths from selected disease groups that could have been potentially avoided through good quality health care. Data based on Eurostat's list.

Source: OECD (2016), OECD Health Statistics (database) and Eurostat (2016), Health Statistics (database). 
Table 1. Health outcome performance

\begin{tabular}{|c|c|c|c|c|c|c|c|}
\hline & $\begin{array}{c}\text { Life } \\
\text { expectancy } \\
\text { at birth, total } \\
\text { population }\end{array}$ & $\begin{array}{c}\text { Life } \\
\text { expectancy, } \\
\text { Male at } 65, \\
\text { total } \\
\text { population }\end{array}$ & $\begin{array}{c}\text { Life } \\
\text { expectancy, } \\
\text { Female at } 65, \\
\text { total } \\
\text { population }\end{array}$ & $\begin{array}{c}\text { Mortality rate, } \\
\text { all causes }\end{array}$ & $\begin{array}{c}\text { Infant } \\
\text { mortality rate }\end{array}$ & $\begin{array}{l}\text { Premature } \\
\text { mortality }\end{array}$ & Average \\
\hline Chile & 0.6 & 1.1 & 0.4 & 1.6 & -0.8 & 0.7 & 0.6 \\
\hline Czech Republic & -0.4 & -0.7 & -1.0 & -0.8 & 0.9 & 0.6 & -0.2 \\
\hline Estonia & -0.6 & -0.9 & 0.3 & -0.2 & 0.9 & -1.0 & -0.2 \\
\hline Hungary & -1.7 & -1.6 & -1.5 & -1.8 & -0.5 & -0.9 & -1.3 \\
\hline Israel & 1.6 & 1.9 & 0.5 & 1.8 & 0.2 & 0.5 & 1.1 \\
\hline Poland & -0.3 & -0.1 & 0.2 & -0.1 & -0.5 & -0.5 & -0.2 \\
\hline Slovak Republic & -1.1 & -1.3 & -1.6 & -1.2 & -1.3 & -0.8 & -1.2 \\
\hline Slovenia & 1.3 & 0.8 & 0.9 & 0.6 & 1.2 & 0.9 & 1.0 \\
\hline Spain & 1.4 & 1.0 & 2.2 & 1.4 & 1.5 & 2.1 & 1.6 \\
\hline OECD & 0.0 & 0.0 & 0.0 & 0.0 & 0.0 & 0.0 & 0.0 \\
\hline Minimum & -2.5 & -2.2 & -1.6 & -1.9 & -2.4 & -3.5 & -2.2 \\
\hline Adjusted $\mathrm{R}^{2}$ & 0.59 & 0.61 & 0.41 & 0.58 & 0.41 & 0.57 & - \\
\hline
\end{tabular}

Note: This performance indicator is based on the estimation of regression residuals explaining the health system outcomes of 31 OECD countries evaluated by 6 different criteria by their per capita GDP and explanatory variables capturing lifestyle and/or social factors. These 6 criteria are those of the columns in the table above. For each criterion, the performance indicator is calculated as the residual of the corresponding regression divided by the standard deviation of the residuals. By construction, the average of each indicator across the sample of OECD countries is equal to 0 . A negative residual indicates a below OECD average performance in terms of efficiency of health outcomes for the corresponding criterion analysed. For example, for the life expectancy at birth, the residual for Slovakia is 1.1 time the standard deviations of the residuals for the 31 OECD countries, controlling for GDP per capita and other explanatory variables.

The regression run for each criterion (in logs) on the available data for 31 OECD countries includes a constant and a set of the following explanatory variables (in logs) on the right hand side: GDP per capita in PPP terms; the share of the population aged 15+ who are daily smokers; alcohol consumption in litre per capita for the population aged 15+; share of the population aged 25 to 64 with at least upper secondary education; and share of the population aged 15+ for daily consumption of fruits and vegetables. The appendix provides more detailed information about the explanatory variables kept in each regression, which depend on their

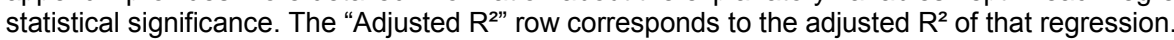

Source: OECD calculations based on OECD (2016), OECD Health Statistics (database).

Health outcomes have undeniably improved over the last ten years, but life expectancy and infant mortality have not progressed more rapidly than the OECD average, and health-adjusted life expectancy did not increase between 2007 and 2014 (Figure 2). Overall, the reduction in the gap in Slovak living standards with the OECD average over the last decade has not been matched by similar progress in health outcomes.

\section{Large health inequalities exist between the Roma and non-Roma population}

These health indicators also show wide disparities within the country, and especially between the Roma community and the rest of the population. Despite a lack of reliable statistics for the Roma people, who account for an estimated $8 \%$ of the population, available surveys highlight their poor health conditions. Recent research in three districts in the eastern part of the country reveal an average life expectancy shortfall of around 10-20 years relative to that of other local inhabitants (Figure 3, Panel A) (Soltès et al., 2014; Gavurová et al., 2014). The situation is even worse for communities living apart from the rest of the population, which account for one half of all Slovak Roma. In some districts these marginalised groups have a life expectancy of barely 43 years, compared with 70 years for non-Roma people (Panel B) (Soltès et al., 2014). 
Figure 3. Selected health indicators of the Roma and non-Roma population
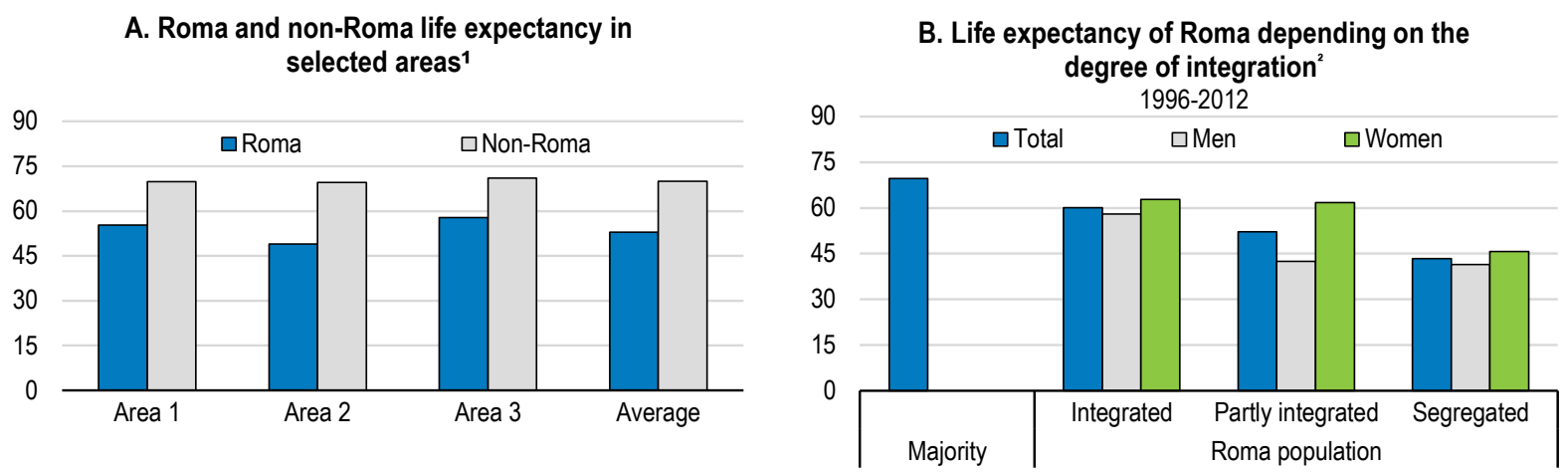

C. Mortality by age group in Roma and non-Roma population of selected areas ${ }^{1}$

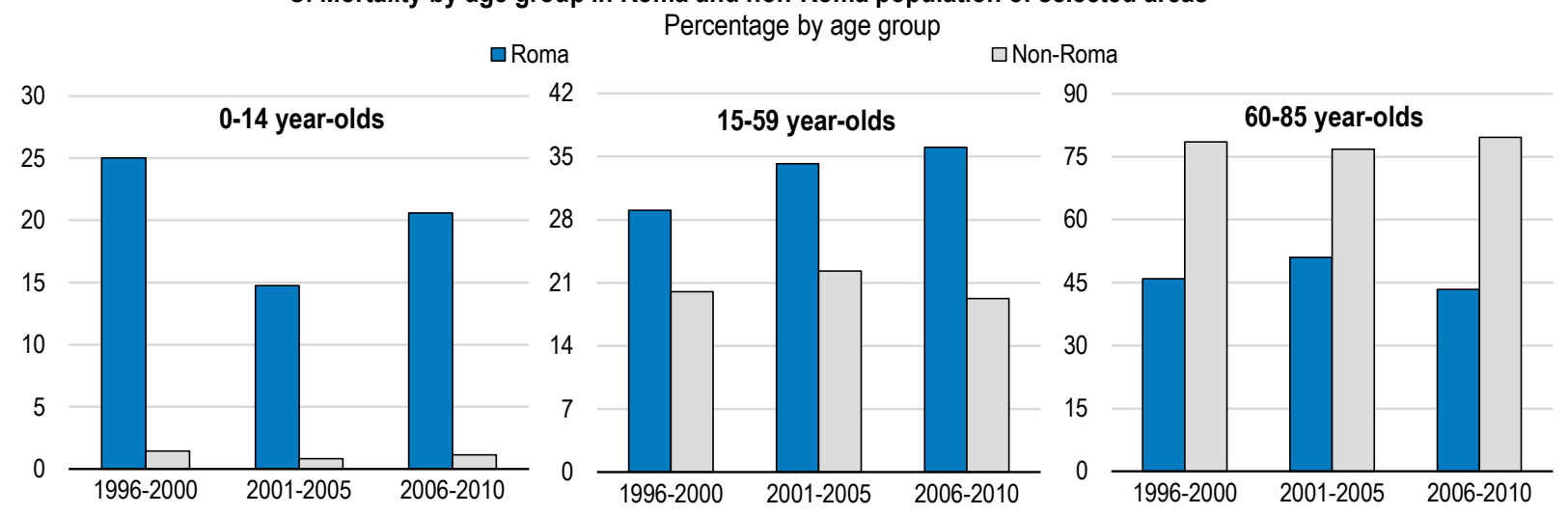

1. Research based on field work in three areas with each Roma community representing 10 to $25 \%$ of the total population. Area 1 had a Roma population share of $10.5 \%$ of the total population, which was 104411 on 31th December 2013; area 2 had a Roma population share of $26.1 \%$ of the total population, which was 71977 ; and area 3 had a Roma population share of $14.8 \%$ of the total population, which was 33444 .

2. Roma population living in area 2.

Source: B. Gavurová et al. (2014), "Meranie zdravia a zdravotných rizík vo vybraných rómskych osadách na Slovensku - fakty a reflexie", in Nerovnost' a chudoba v Európskej únii a na Slovensku, 22-24 October, Košice, and V. Šoltés et al. (2014), "Vývoj mortality v regiónoch s vysokou koncentráciou rómskeho obyvatel'stva", in Nerovnost' a chudoba v Európskej únii a na Slovensku, 2224 October, Košice.

The Roma population's poor health indicators are attributable to very high mortality rates among young people, especially the 0-14 age group, but also 15-59 year-olds (Figure 3, Panel C). It is probable that the strong Roma presence in the central and eastern parts of the Slovak Republic is contributing to the significant regional disparities for infant mortality, although it is not known to what extent (Figure 4) (Ineko, 2015). It is, moreover, hard to assess the impact of the trend in Roma health outcomes since the mid-1990s on the Slovak Republic's lack of convergence with other countries' outcomes. This lack of information complicates the analysis, because the Roma people's poor health conditions only partly reflect failings in the health-care system: they are also the result of a considerable number of social problems afflicting this community, including poverty, malnutrition, deficient education, inadequate sanitation infrastructure and unhealthy lifestyles (Gavurová et al., 2014; Gatti et al., 2016). 
Figure 4. Regional disparities of infant mortality in OECD countries

Deaths per 1000 live births, 2013

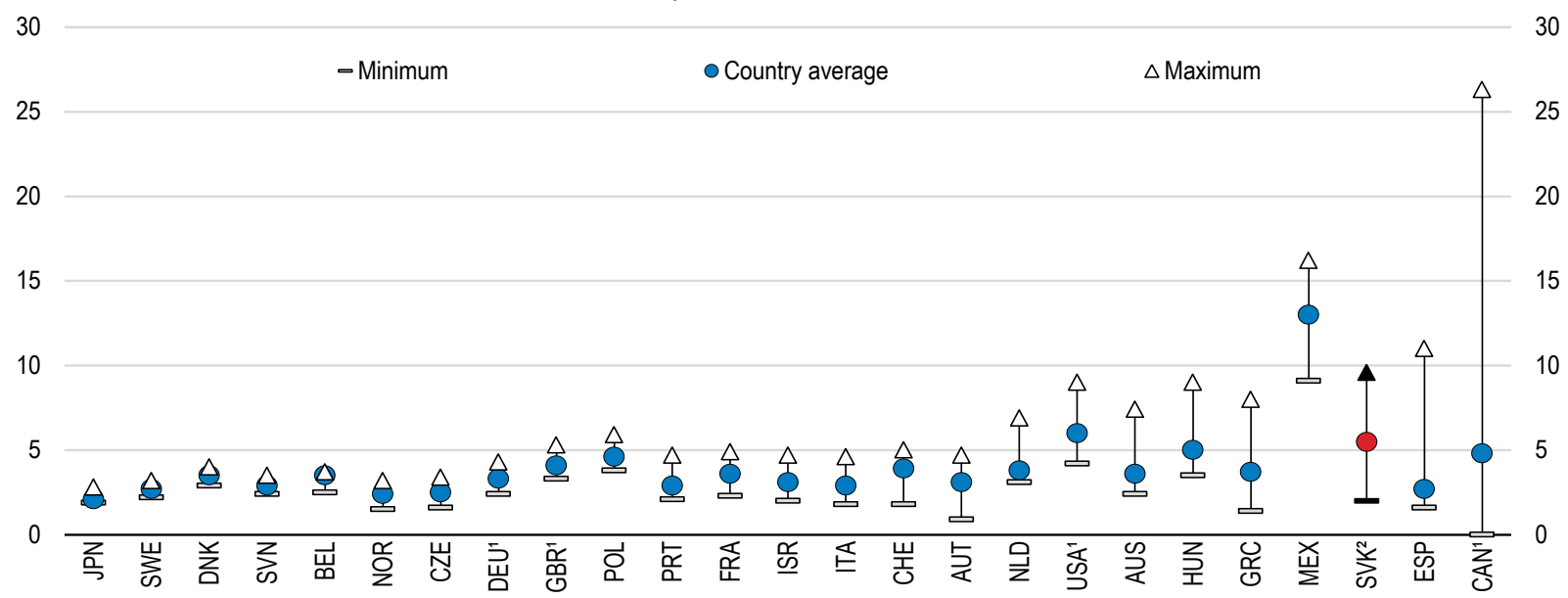

1. 2011 for Canada and 2012 for Germany, the United Kingdom and the United States.

2. In the Slovak Republic, East Slovakia has the highest value and the Bratislava Region the lowest.

Source: OECD (2016), OECD Regional Statistics (database).

Health inequalities related to socioeconomic status, on the other hand, are not especially large, which suggests they are probably limited within the non-Roma population. As in other OECD countries life expectancy is longer for those with a tertiary degree than those with less education, especially among men (Figure 5, Panel A). But the differences in this domain are similar to the OECD average and smaller than for the other central European countries. Health inequalities by income, measured by differences in selfreported health, are also moderate (Panel B). The gap between the share of people reporting their health to be good in the top and bottom income quintiles is near the OECD average at about 17 percentage points in 2013: $78 \%$ as compared with around 60\% (OECD, 2015a).

Figure 5. Health inequalities by socioeconomic status
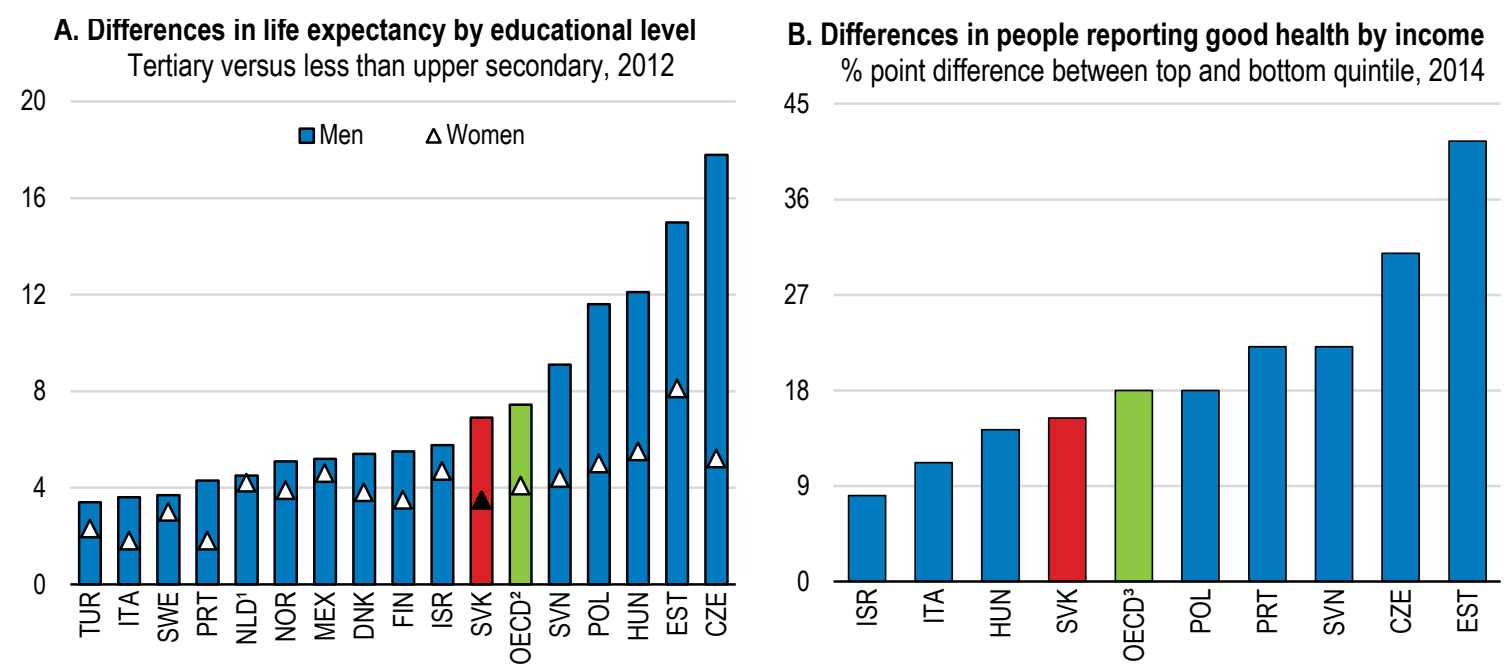

1. 2011 for Netherlands.

2. Unweighted average of the data shown.

3. Unweighted average.

Source: OECD (2016), OECD Health Statistics (database) and C. James et al. (2015), "Inclusive Growth and Health", DELSA/HEA(2015)14, OECD Publishing, Paris. 


\section{The operation of the health-care system is a source of deep discontent}

These poor health outcomes are one reason why Slovaks are so dissatisfied with their health-care system compared with other Europeans (Figure 6). The high degree of dissatisfaction has not changed since 2007 despite several reforms. This reveals the system's ongoing failure to meet the basic standards expected by its users.

Figure 6. Satisfaction with the healthcare system ${ }^{1}$

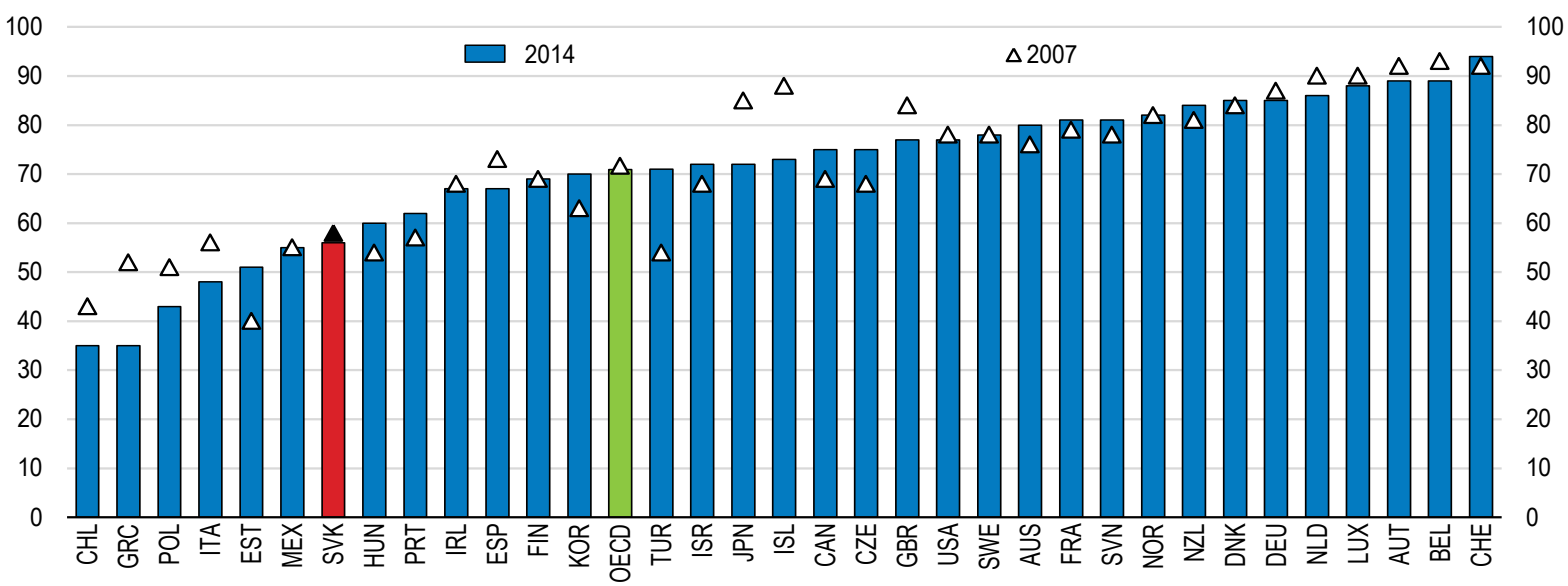

1. Data for Austria, Finland, Ireland, Norway, Portugal, the Slovak Republic, Slovenia and Switzerland are for 2006. Data for Iceland and Luxembourg are for 2008. Data for Australia, Canada, Chile, Hungary, Iceland, Japan and Korea are for 2013.

Source: OECD (2015), Health at a Glance 2015: OECD Indicators.

This discontent is partly driven by the non-negligible level of private health costs directly paid by consumers, for reasons that are often poorly understood. At somewhat above $20 \%$ of total health spending on average between 2012 and 2014, this slightly exceeded the OECD average (Figure 7). These out-ofpocket payments include the purchase of medicines and administrative charges not covered by health insurance, the scope of which is not always clearly defined. In addition to co-payments for prescribed drugs, direct payment for OTC pharmaceuticals and user fees for various services, that are not included in the healthcare basic package, the latter include requests for medical certificates, and such services as care for "uncooperative children". The amount paid by patients varies between doctors for reasons that are hard to explain. The number of complaints to regional watchdogs concerning payments that are felt to be arbitrary and unjustified is rising every year.

Slovaks perceive their health-care system as more corrupt than their counterparts in other EU countries and more corrupt than other areas of the administration (Figure 8). The main reason for this perception is the flawed management of public procurement, which is a serious problem in hospital purchasing (EC, 2013). These issues have occasionally triggered political scandals and often lead to price surcharges of between 50\% and 100\% (EC, 2013; The Economist, 2014), a situation due to both weak policing and punishment of corruption, poor hospital management and inadequate regulation of public procurement (Ineko, 2012a and 2012b). The authorities recently started to address these failings (see below), but corruption takes other forms, including informal payments, which some studies suggest concern over 70\% of doctors' visits. According to Muzik and Szalayova (2013), more than $20 \%$ of these payments are made as a kind of thank-you gift, which might be a box of chocolates or sweets, rather than a bribe. But almost half of patients felt they represented an act of corruption voluntarily offered by the patient or required by the doctor in return for better service, and in such cases generally consisted of a cash payment usually between EUR 100 and EUR 333, although far higher payments have been reported (The Economist, 2015). However, more recent research did not confirm such high numbers and concluded that 
approximately $25 \%$ of respondents gave informal payments, although estimates are stated to be uncertain (Transparency International, 2015).

Figure 7. Household' out-of-pocket expenditure on health care

Percentage of total current expenditure on health care, 2012-2014 average

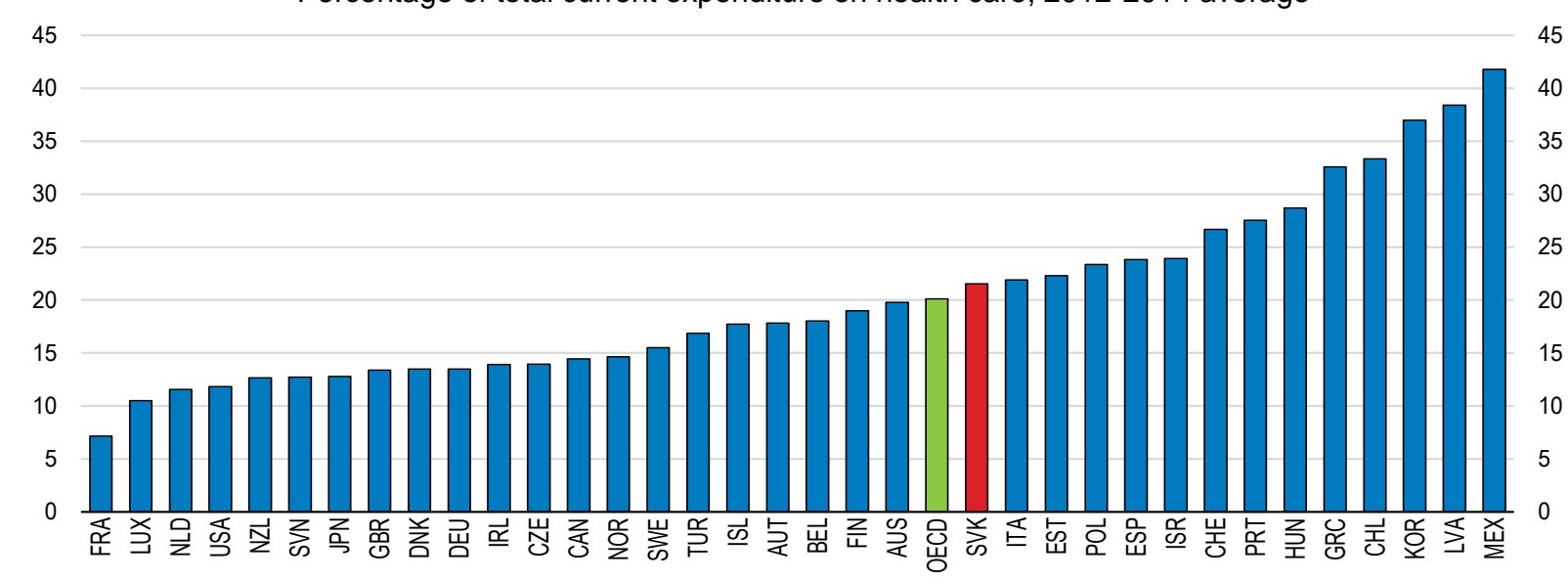

1. Includes non-profit institutions serving households.

2. Unweighted average of the data shown.

Source: OECD (2016), OECD Health Statistics (database).

Figure 8. Perception of corruption in the public healthcare sector

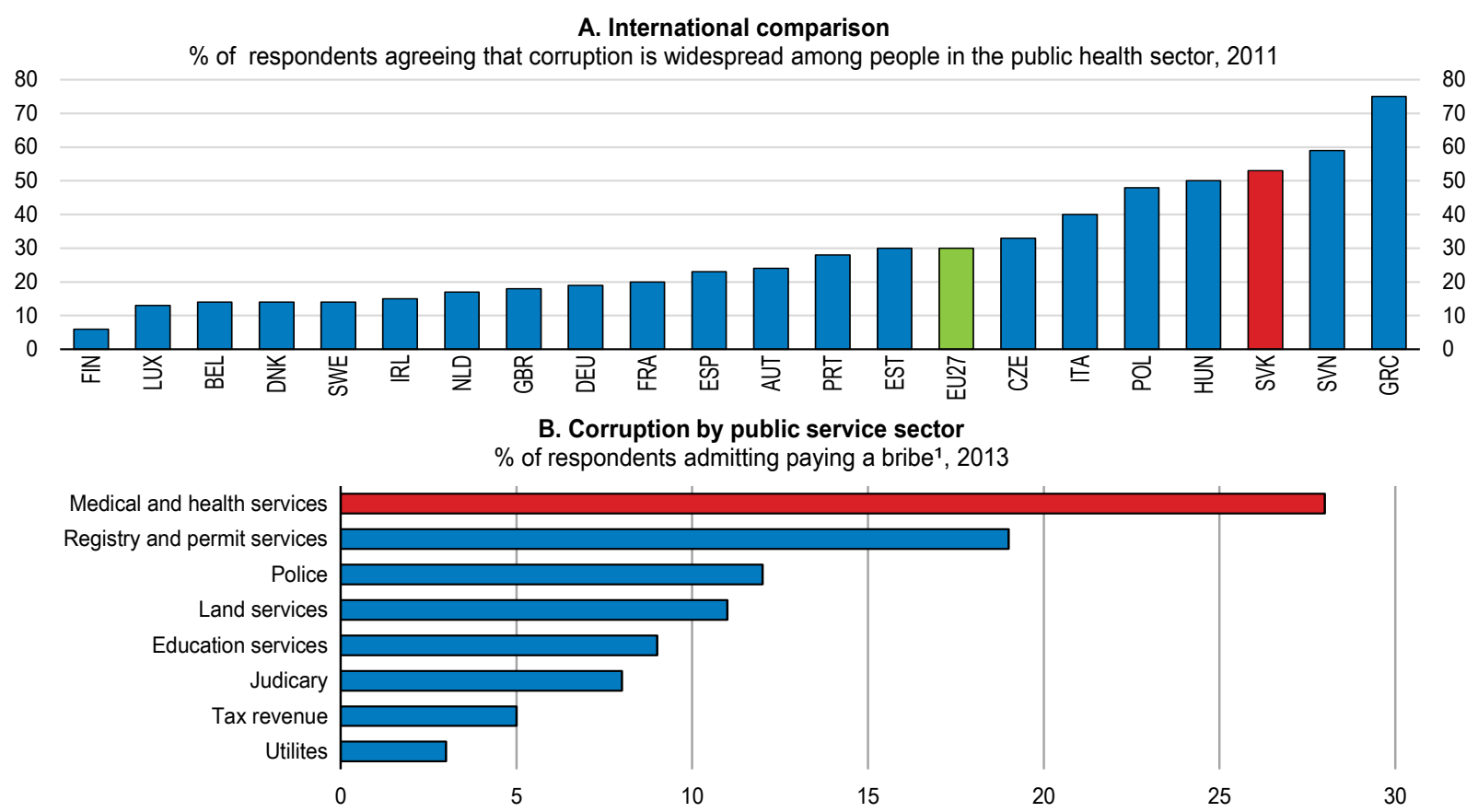

1. Results shown for those who came into contact with a service and who were asked a question such as "Have you or anyone in your household paid a bribe to one of these eight services in the last 12 months?".

Source: European Commission (2012), Special Eurobarometer 374: Corruption (fieldwork September 2011) and Transparency International (http://www.transparency.org).

Public dissatisfaction with the health service also reflects a number of difficulties in accessing outpatient medical services. In theory the health-insurance system provides full medical cover for the whole of 
the population, but accessing these services is easier in big cities than rural areas, especially for Roma communities living in separate districts (i.e. areas where virtually only Roma are living). Slovak doctors, like those in other countries, are not attracted to rural areas, and as general practitioners (GPs) retire from rural practises it is hard to replace them. GPs in rural areas are few in number and often struggle with an excessive workload, which prevents them from responding rapidly to requests for care, especially as GP visits are not normally governed by an appointment system, so that patients typically wait many hours to see the doctor. And while medical insurance companies are obliged to ensure that their care network employs a minimum number of specialists in every region, these providers are generally located in urban centres. Some people are therefore forced to travel long distances, which is itself complicated by the inadequacy of the transport infrastructure. Financial reasons are not the main drivers for unmet health needs in the Slovak Republic, but rather wait times and travel distances to the nearest medical specialists in some regions (WHO, 2016). Furthermore, specialists, who are remunerated by a fee-for-service system constrained by a monthly ceiling, often refuse non-urgent consultations if the monthly resources allocated to their remuneration by the insurance companies have been already exhausted before the end of the month. In that case, although patients have the right to benefit from health care services by another doctor contracted by their insurance company, they generally do not use this option either because they are not aware of it, or because they do not want to change doctor.

As in most other countries, there also exist waiting lists for many non-urgent hospital procedures. Wait times have fallen in recent years and vary according to the service provided. Against an international benchmark they may seem long for hip and knee replacements (Figure 9), for instance, but this may partly reflect Slovaks' ability to choose their doctor. Efforts have been made to improve information about waiting lists. However, they cover only a very small proportion, less than 5\%, of hospital services provided (Dovera, 2016), with the result that in most cases, patients do not know the wait time for many procedures, which causes stress and fuels corruption related to queue jumping.

Figure 9. Average waiting days for elective surgery

Waiting times from specialist assessment to treatment, 2013

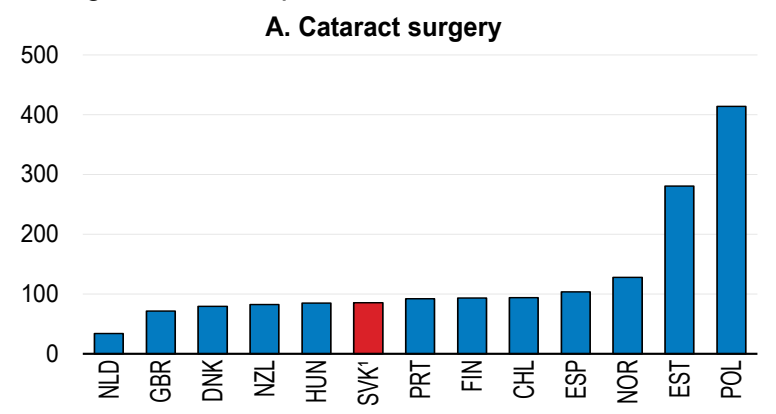

B. Hip replacement

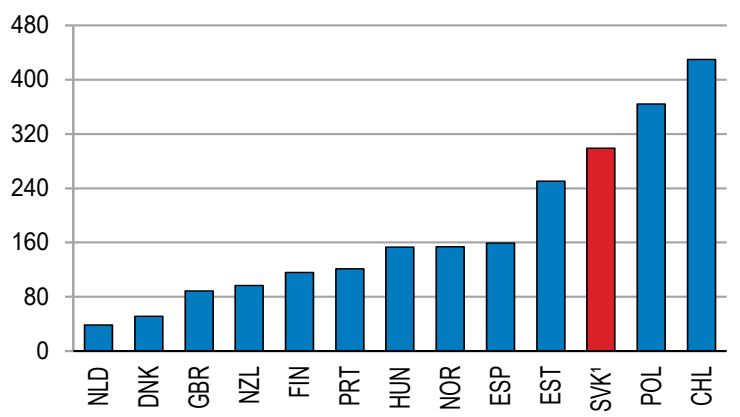

C. Knee replacement

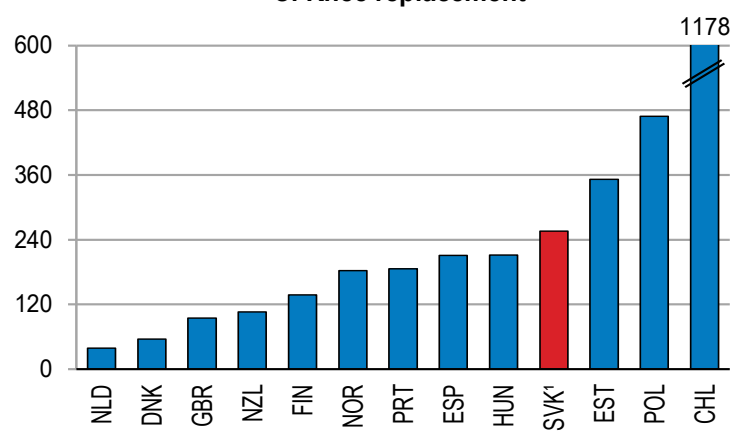

1. The Slovak data is based on a study of Mužík and Szalayová (2013), as unweighted average of data provided by the three health insurance companies. They do not follow the definition for data collected by OECD and are thus not be fully comparable with other countries' statistics.

Source: OECD (2016), OECD Health Statistics (database), except for Slovak Republic: R. Mužík and A. Szalayová (2013), "Časová dostupnost' vybraných elektívnych výkonov: Analýza čakacích dôb", Health Policy Institute. 


\section{Health spending has increased sharply since 2000}

In the years leading up to the 2008-09 crisis, health spending rose sharply before declining somewhat since then (Figure 10, Panel A). This increase reached 10\% per capita per annum in real terms between 2000 and 2009, much more than in other OECD countries (Panel B). Regulatory changes paved the way for a surge in private medical spending, which was initially low compared with other countries (Panel C), while the strong growth in budget revenues induced by the country's catching-up economy up to 2009 also allowed faster spending increases. As in most other OECD countries, moreover, new therapies and increased pay for medical staff have fuelled public health spending (de la Maisonneuve and Oliveira Martins, 2013). The share of this spending in total budget expenditure has therefore seen a marked increase, although it remains below the OECD average (Panel D).

Figure 10. Growth of health-care spending
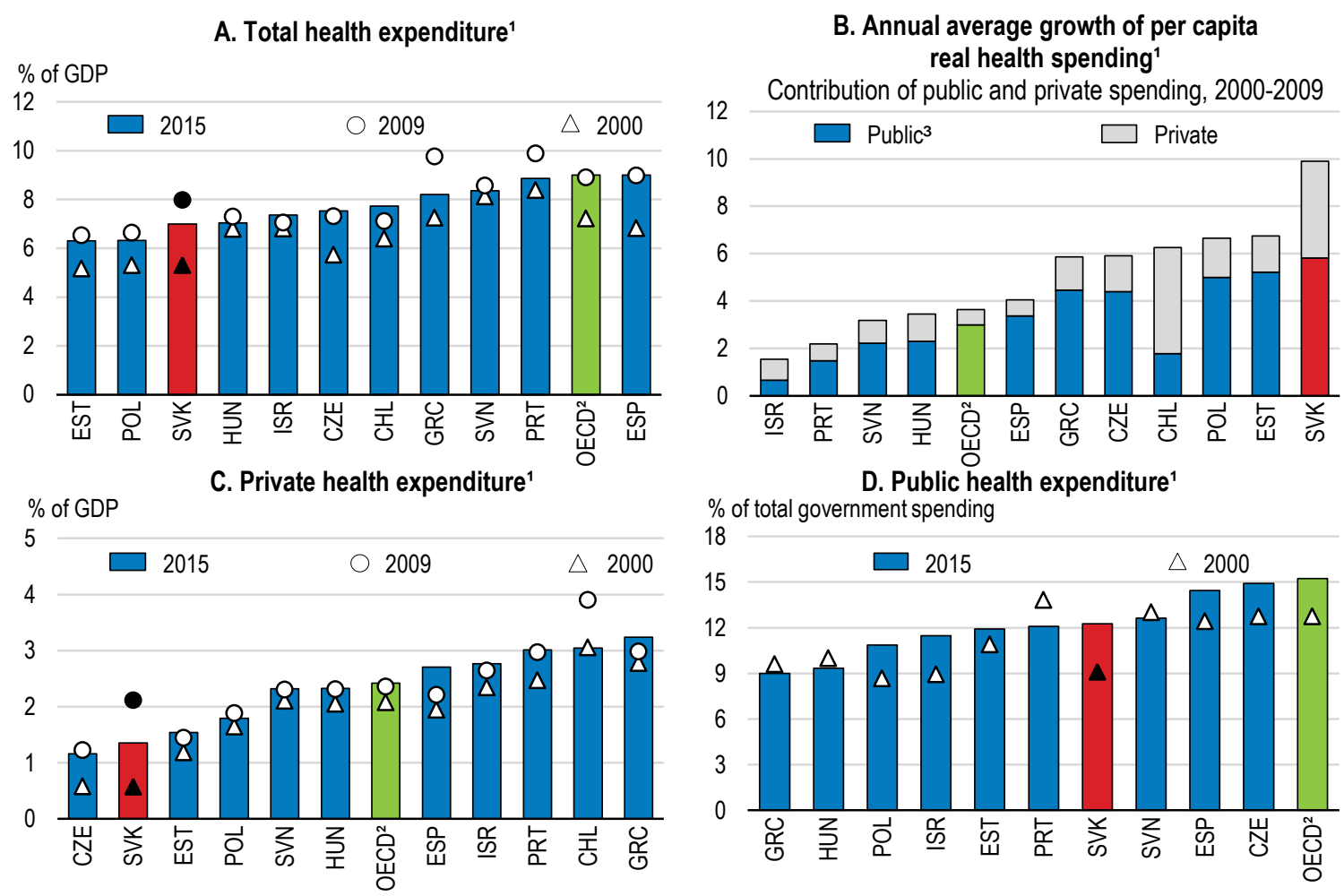

1. Excludes investment. All data in 2015 are estimated or provisional.

2. Unweighted average. For Panel D, government spending data in 2013 for Mexico and 2014 for Japan and New Zealand.

3. Government schemes and compulsory contributory health care financing schemes.

Source: OECD (2016), OECD Health Statistics (database) and OECD calculations based on OECD (2016), OECD Health Statistics (database) and OECD Economic Outlook: Statistics and Projections (database).

Slovak health spending stood at $7.0 \%$ of GDP in 2014, which is not high, given the country's GDP per capita, but is higher than spending in other central European countries (Figure 11, Panel A). The composition of medical spending also differs from the OECD average (Panel B), with a larger share for pharmaceuticals and a small share of spending on hospitals and long-term care, although the latter is probably underestimated (see below). 
Figure 11. Expenditure on health

A. Total expenditure on health ${ }^{1}$

2015

Total expenditure on health as $\%$ of GDP, log

3.0

$\triangle$ USA

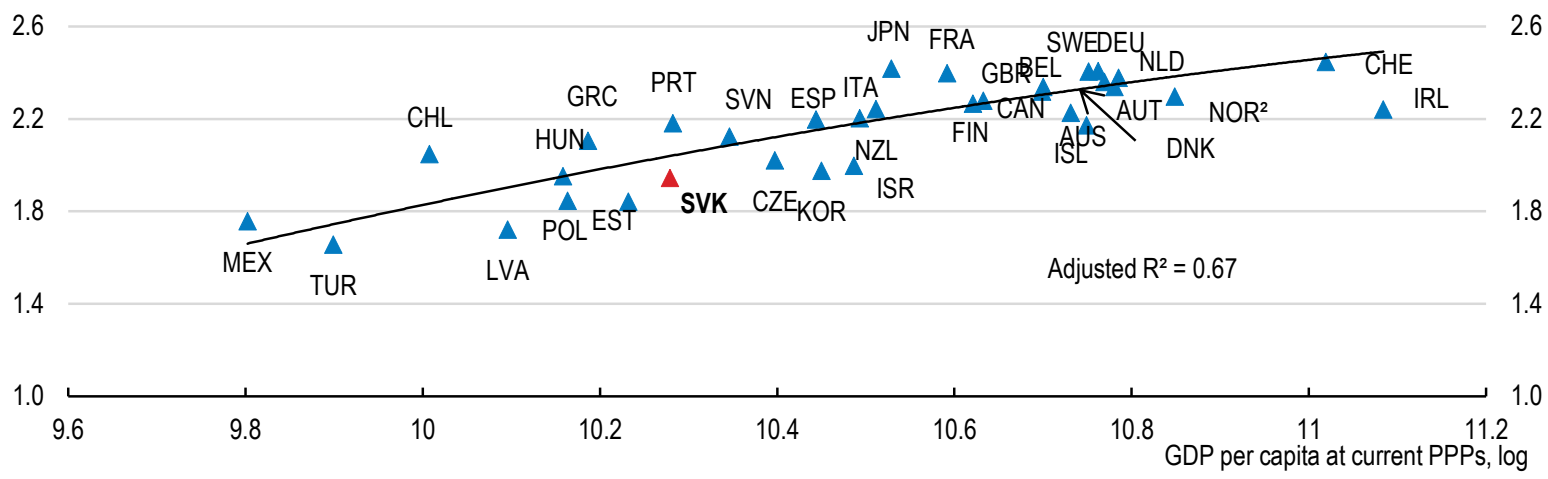

B. Total health expenditure ${ }^{1}$ by function

2014 or nearest year unless specified

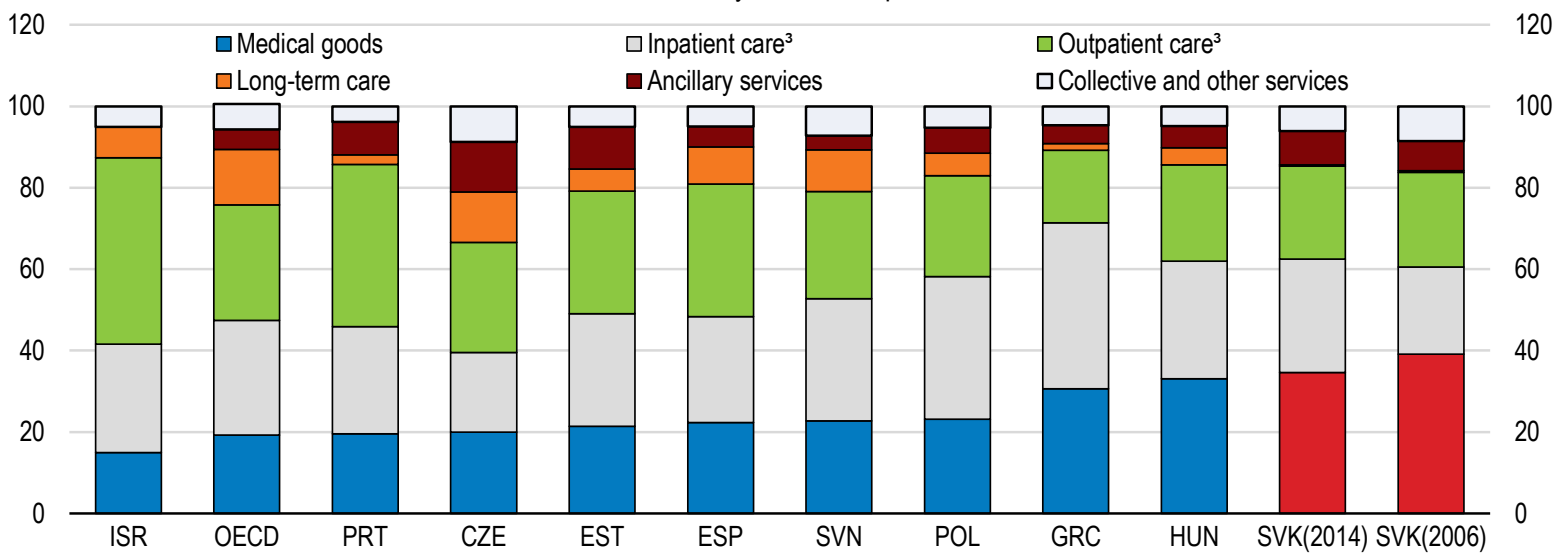

1. Excludes investment.

2. Mainland GDP for Norway.

3. Inpatient care includes curative-rehabilitative care in inpatient and day care settings. Outpatient care includes curativerehabilitative care in outpatient and home-care services.

Source: OECD (2016), OECD Health Statistics (database) and OECD (2016), OECD National Accounts Statistics (database).

\section{There seems to be significant room for improving the efficiency of the health-care system}

Most international comparisons measuring the efficiency of health-care systems highlight the shortcomings of the Slovak system (Medeiros and Schwierz, 2015). These studies, which generally rely on data envelopment analysis, also reveal a deterioration in efficiency over the last 10 years (Dutu and Sicari, 2016; Filko et al., 2012) (Figure 12). In particular, amenable mortality has declined more slowly in the Slovak than in the Czech Republic, whereas the two countries had long displayed a comparable performance (Kossarova et al., 2012). As mentioned above, improvements in health outcomes since the early 2000s have indeed been modest in the light of the strong rise in health spending during this period. 
Figure 12. Potential efficiency gains in health care
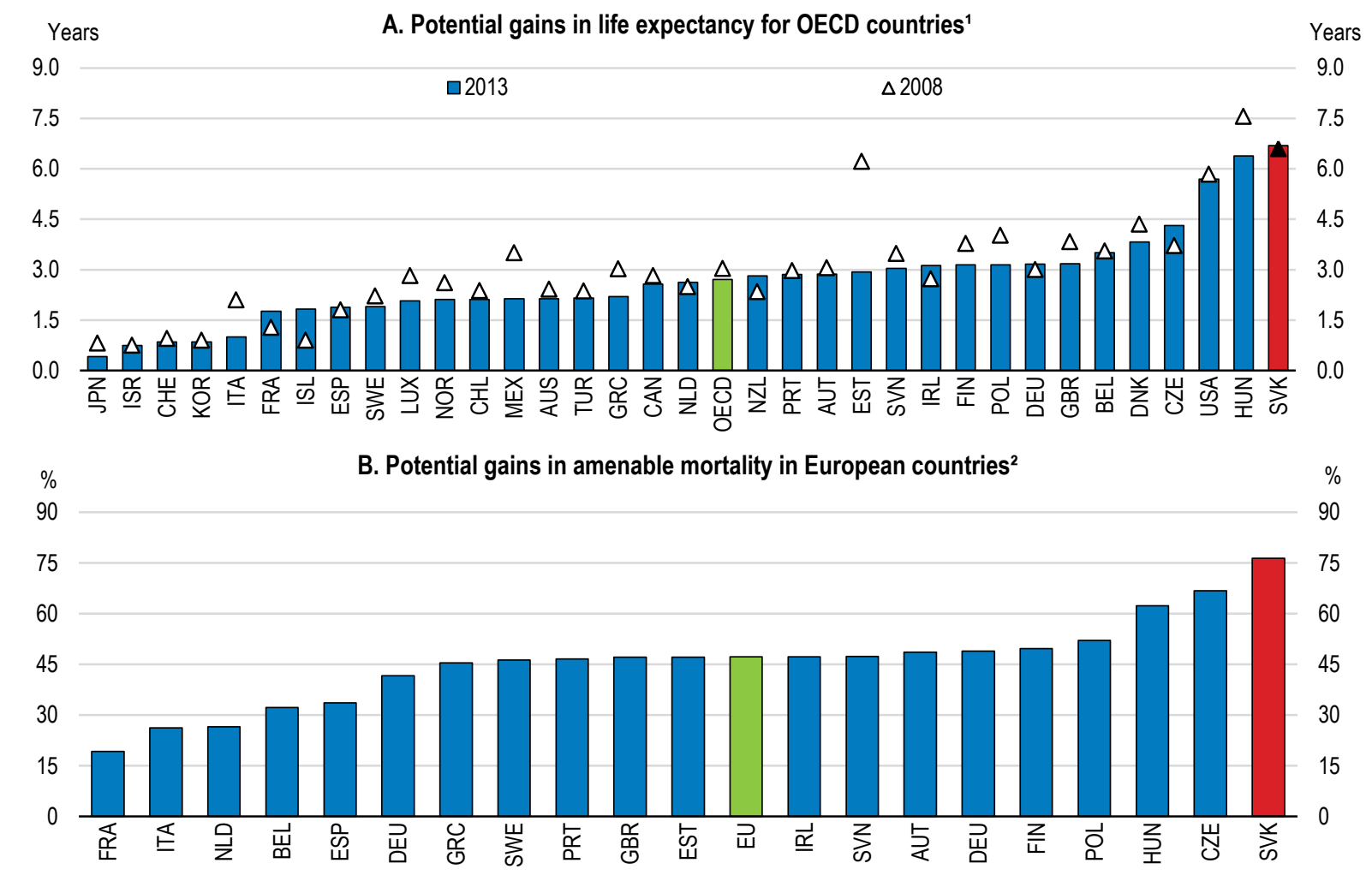

1. Data envelopment analysis (DEA) was performed with one output (life expectancy at birth) and two inputs (a composite indicator of the socio-economic environment and lifestyle factors and health-care spending). Potential gains are measured if efficiency in a country were to be raised to the level implied by the estimated efficiency frontier while holding inputs constant and under the assumption of non-increasing returns to scale.

2. Data envelopment analysis (DEA) was performed with one health outcome variable (amenable mortality per 100000 inhabitants in 2011 for which causes of death selected are based on AMIEHS, i.e. the project on Amenable mortality in the European Union: toward better indicators for the effectiveness of health systems, and availability in Eurostat) and different input variables in three models. Potential gains are estimated by measuring the proportion of amenable mortality that could be reduced, if a country moves from inside to the efficiency frontier, while holding inputs constant.

Source: R. Dutu and P. Sicari (2016), "Public Spending Efficiency in the OECD: Benchmarking Health Care, Education and General Administration", OECD Economics Department Working Papers, No. 1278, with updated estimates provided by the authors and European Commission (2015), J. Medeiros and C. Schwierz, "European economy: Efficiency estimates of health care systems", Economic Papers, No.549.

The extent of this efficiency problem is nevertheless hard to ascertain. It is not easy to distinguish between the effects of a dysfunctional health-care system on a country's health outcomes and those of the population's prevailing socio-economic conditions and lifestyles. Recent research, factoring in certain socio-economic metrics (GDP per capita, average level of adult education) and lifestyle indicators (consumption of fruit and vegetables, tobacco and alcohol) has found the Slovak health system to be one of the European Union's and OECD's least efficient (Dutu and Sicari, 2016; Medeiros and Schwierz, 2015). According to this analysis, if health spending was spent as efficiently as in the top-ranking countries, Slovaks' life expectancy at birth in 2013 would have been extended by over six years (Figure 12), or twice as much as the estimated extension for the EU or the average OECD country. These results seem, furthermore, to be fairly robust, since they are not much affected by the inclusion of unhealthy lifestyle measures, such as excessive tobacco and alcohol consumption and obesity, which are quite evenly distributed across most countries (EC, 2015a). Nevertheless, these aggregate measures of efficiency do not account for a wide range of non-medical determinants of health outcomes, including social and cultural 
factors, which influence life expectancy. In the case of the Slovak Republic, for instance, Tunega (2013) and Hadad et al. (2013) find that the poverty and lifestyle difficulties of the Roma community play an important role in the country's poor overall health outcomes. Although these studies are not able to provide an in-depth analysis of this question because of the absence of relevant data, their results are plausible. The socio-economic and lifestyle problems affecting the Roma are far more severe than those of the rest of the population, and the share of the Roma community seems to be growing (Sprocha, 2014 and see OECD, 2017c).

\section{A more effective health-care system would have economic and fiscal benefits and promote well-being}

There are many potential benefits from a better health-care system: first, increased well-being of the population. More effective health-care supply also has a positive impact on the economy: healthy people are more productive and more active, with less absenteeism and longer working lives, which is especially important in the light of rapid population ageing. In this context, efficiency gains are also valuable because of increased income-sensitive demand for medical services and their higher costs, driven by technological advances and rising prices for such services, while the authorities need to contain public spending to maintain sound public finances. Public spending on health and long-term care could increase by $33 / 4$ percentage points of GDP by 2060, close to the OECD average of $3 \frac{1}{4}$ percentage points (de la Maisonneuve and Oliveira Martins, 2013) (Table 2). Research produced by the European Commission confirms the intensity of these pressures, albeit with a different assessment of their extent (EC, 2015b).

Ensuring universal access to high-quality health care while keeping spending under control will be challenging. The authorities are aware of the need to increase efficiency, and they started a broad public spending review in the first half of 2016, beginning with health care. The room for saving by reducing wasteful spending, which is estimated at $20 \%$ of health expenditure in the average OECD country, is considerable (OECD, 2017a). However, optimising the use of resources must form part of a comprehensive approach to health policy that pays close attention to the specific difficulties of the most vulnerable population groups. Improving the health of underprivileged communities matters not just because it improves effectiveness, but also because it is more inclusive and will help to reduce the high rate of amenable mortality. 
Table 2. Projected increases in public health and long term care spending by main source, 2010-60

Percentage points of GDP

\begin{tabular}{|c|c|c|c|c|c|c|}
\hline & \multicolumn{3}{|c|}{ OECD (2010-2060) } & \multicolumn{3}{|c|}{ European Commission (2013-2060) } \\
\hline & Health care & Long-term care & Total & Health care & Long-term care & Total \\
\hline Australia & 2.5 & 0.8 & 3.3 & - & - & - \\
\hline Austria & 2.4 & 0.7 & 3.1 & 1.6 & 1.3 & 2.9 \\
\hline Belgium & 1.9 & 0.7 & 2.6 & 0.5 & 1.5 & 2.0 \\
\hline Canada & 2.5 & 0.7 & 3.2 & - & - & - \\
\hline Chile & 3.2 & 1.5 & 4.7 & - & - & - \\
\hline Czech Republic & 2.2 & 0.9 & 3.1 & 1.2 & 0.7 & 1.9 \\
\hline Denmark & 2.0 & 0.6 & 2.6 & 1.0 & 2.2 & 3.2 \\
\hline Estonia & 2.0 & 0.9 & 2.9 & 0.8 & 0.7 & 1.5 \\
\hline Finland & 2.0 & 0.5 & 2.5 & 1.1 & 1.9 & 3.0 \\
\hline France & 2.2 & 0.6 & 2.8 & 1.1 & 0.9 & 2.0 \\
\hline Germany & 2.3 & 0.7 & 3.0 & 0.7 & 1.4 & 2.1 \\
\hline Greece & 2.5 & 0.9 & 3.4 & 1.4 & 0.5 & 1.9 \\
\hline Hungary & 1.9 & 1.0 & 2.9 & 1.0 & 0.4 & 1.4 \\
\hline Iceland & 2.0 & 0.5 & 2.5 & - & - & - \\
\hline Israel & 2.5 & 0.6 & 3.1 & - & - & - \\
\hline Ireland & 2.5 & 0.7 & 3.2 & 1.3 & 0.9 & 2.2 \\
\hline Italy & 2.6 & 0.8 & 3.4 & 0.8 & 1.0 & 1.8 \\
\hline Japan & 2.5 & 0.8 & 3.3 & - & - & - \\
\hline Korea & 3.7 & 1.3 & 5.0 & - & - & - \\
\hline Luxembourg & 3.0 & 0.7 & 3.7 & - & - & - \\
\hline Mexico & 3.0 & 1.5 & 4.5 & - & - & - \\
\hline Netherlands & 2.4 & 0.8 & 3.2 & 1.2 & 3.3 & 4.5 \\
\hline New Zealand & 2.4 & 0.8 & 3.2 & - & - & - \\
\hline Norway & 2.2 & 0.5 & 2.7 & 1.2 & 3.5 & 4.7 \\
\hline Poland & 2.6 & 1.0 & 3.6 & 1.3 & 0.9 & 2.2 \\
\hline Portugal & 2.6 & 0.8 & 3.4 & 2.8 & 0.4 & 3.2 \\
\hline Slovak Republic & 2.6 & 1.1 & 3.7 & 2.2 & 0.4 & 2.6 \\
\hline Slovenia & 2.7 & 0.9 & 3.6 & 1.4 & 1.4 & 2.8 \\
\hline Spain & 2.8 & 1.0 & 3.8 & 1.0 & 1.6 & 2.6 \\
\hline Sweden & 2.0 & 0.5 & 2.5 & 0.6 & 1.6 & 2.2 \\
\hline Switzerland & 2.6 & 0.7 & 3.3 & - & - & - \\
\hline Turkey & 3.1 & 1.6 & 4.7 & - & - & - \\
\hline United Kingdom & 2.0 & 0.5 & 2.5 & 1.5 & 0.4 & 1.9 \\
\hline United States & 2.2 & 0.4 & 2.6 & - & - & - \\
\hline OECD average ${ }^{1}$ & 2.5 & 0.8 & 3.3 & - & - & - \\
\hline
\end{tabular}

1. Unweighted average.

Source: C. de la Maisonneuve and J. Oliveira Martins (2013), "A Projection Method for Public Health and Long-Term Care Expenditures", OECD Economics Department Working Papers, No. 1048; European Commission (2015), "The 2015 ageing report: Economic and budgetary projections for the 28 EU Member States (2013-2060)". 


\section{Improving the health-care system will require reforms in several areas}

\section{Increasing the coherence of the organisation of the system}

All OECD countries face difficult regulatory issues in the health-care arena. Demand for medical services must be channelled through an insurance mechanism to allow everybody to access care despite the potentially high cost by pooling the risk. The problem with such a system, which in the Slovak Republic is based on three insurance funds (Box 1), is incentives, a problem which is exacerbated by the asymmetry of information between insurers, providers and the insured (i.e. patients). Regulation has a central role to play in securing high-quality health-care provision at an affordable cost, particularly by encouraging insurers to promote these objectives without appropriating an excessive share of the funds devoted to health care in the form of administrative costs or profits. Spending control and effectiveness also depend on the insurers' ability and incentives to negotiate low prices with providers and to encourage them to increase their efficiency and quality. In the presence of multiple insurers, as in the Slovak Republic, this in turn requires adequate and healthy competition between these funds. Furthermore, it is important to counter the moral hazard problem created by the insurance system, as it encourages people to over-consume. Another source of over-consumption to be resisted is supplier-induced demand. Hence, both supply and demand must be regulated.

\section{Box 1. The Slovak health-care system}

The organisation of the Slovak health-care system is the culmination of successive reforms adopted during the past 13 years. This box provides a short summary of these reforms followed by the main features of the current system.

\section{A brief history of health sector reforms since the mid-2000s}

The successive reforms that have reorganised the Slovak health-care system began with the Zajac reform in 2004, which was principally designed to replace the state health-care system with a more market-based system in order to solve the inefficiency problems and recurrent deficits in the country's health insurance system by making the following major changes (Colombo and Tapay, 2004; Szalay, 2011):

- Changing the insurance funds from non-profit organisations to private companies entitled to make profits,

- $\quad$ Contractualising relations between insurers and providers, with insurers given free rein in negotiations to exercise provider selection. Insurers were nevertheless required to sign contracts with all emergency care units, all pharmacies and all general practitioners, and to ensure a minimum medical network in every region.

- Introducing or increasing co-payments made by patients for drugs, consultations, hospital stays and the use of emergency services to prevent the overuse of medical care.

The changes to the system introduced in the wake of the Zajac reform largely consisted of attempts to roll back or restrict the range of these measures, or efforts to restore them, depending on which party was in power:

- The right of insurers to make profits was banned between 2008 and 2010. It was restored in 2011 when it was declared unconstitutional, and a renewed profits ban was part of the proposals of the new government elected in 2016. The programme of the government in power between 2012 and 2016 included the replacement of the three health insurers by a single public insurer, i.e. the adoption of a single-payer system. But the proposal was never implemented, partly for financial reasons linked to the high cost of buying out the private insurers.

- In 2007 the leeway given to insurers for selective negotiations with health-care providers was reduced by requiring them to include all state hospitals in their minimum health-care networks. This clause was removed in 2010-11 and then restored in 2012.

- Co-payments for many services were abolished between 2006 and 2010, then partially reintroduced between 2010 and 2011 and restrained again since 2012.

- $\quad$ Similarly, the gatekeeper system for access to specialist care introduced in 2006 was abolished in 2010-11 and reintroduced in 2013. 


\section{The main features of the health system's current structure Cover, rights to services and the financing of health insurance}

The implementation of public health insurance in the Slovak Republic is an activity carried out in the public interest on the basis of the principle of solidarity. The activity of health insurers in the provision of health insurance is strictly regulated because they manage public funds, which requires a close control by the state. The principle of solidarity means that the contribution to the health insurance system is not linked to the extent of the healthcare services received, nor determined by health insurance companies, but set by the state.

More specifically,

- Health insurance is financed from public resources, which are compulsory and redistributed on the basis of the principle of solidarity. Health-insurance scheme is funded by contributions from employers and employees and a state contribution for the inactive. Work-related health-insurance contributions amount to $14 \%$ of gross pay ( $4 \%$ paid by the employee and $10 \%$ by the employer). The same $14 \%$ rate applies to the self-employed. People with disabilities enjoy a reduced rate of $7 \%$. The state pays for the health insurance of the inactive - primarily children, the unemployed and pensioners. Its contribution amounts to about $4 \%$ of average pay (Huefner, 2011), with some fluctuations from year to year, since the state generally adjusts its contribution to take account of specific factors affecting the funding of health spending, such as salary adjustments for hospital doctors.

- The health insurance system is universal. It guarantees to each individual the free choice of their health insurance company, and health insurance companies cannot reject insured persons.

- Healthcare is provided to every policyholder according to his/her needs, to the extent provided for by a specific regulation, and not according to his/her financial ability to pay.

In theory, this system entitles people to free health care, with some exceptions (such as cosmetic surgery and a significant proportion of dental care). In practice, however, the share of total medical costs paid directly by the consumer amounted to $18 \%$ in 2014 , down from more than $23 \%$ in 2012 . This figure includes medicines and care not covered by health insurance, as mentioned above.

\section{How the insurance scheme works}

People can choose between three insurance companies: the public insurer, $V S Z P$, and two private insurers, $Z P$ Dovera and ZP Union, whose share by number of policyholders were 64\%, 28\% and 8\%, respectively, in 2015. Policyholders can change insurer every year, and insurers are not allowed to refuse customers. To prevent insurers selecting the most "profitable" patients ("cream skimming"), their funding includes an equalisation system to offset risk variation. It is based on the age and gender of the policyholder, economic activity and, since 2012, on the costs of their pharmaceutical spending, which helps to reflect their medical risks more accurately (Vagac et al., 2014). The regulator for the insurance scheme and the risk-compensation mechanism is the Health Care Surveillance Authority, HCSA.

The insurers do not influence the basket of basic services, the level of cover or the contribution rates. Moreover, given the broad, albeit imprecise, definition of the basket of basic insured services, there is no market for voluntary supplementary insurance, and competition between insurers is therefore based on the quality of their service offering (including differences in waiting times), which depends on the contracts they have signed with service providers, who can have different contracts with different insurers based on prices that are generally freely negotiated. As mentioned above, the government has defined a network of minimum service providers with which the insurers must sign contracts.

\section{The organisation of care providers and their remuneration}

Users are free to choose their care providers, although access to specialists is restricted by a gatekeeper system (a role played by general practitioners).

Care providers' remuneration is set by the contracts signed with the insurers, based on mechanisms that vary from sector to sector. In the out-patient sector, GPs are paid per patient (i.e. capitation), with a certain number of procedures paid on a fee-for-service basis, such as vaccinations. Specialists are paid on a fee-for-service basis, but their monthly remuneration is subject to a cap negotiated with the insurers. Hospital care is reimbursed according to the services provided, although it is based on a pricing system that does not reflect costs correctly. A reform to introduce financing according to the price of treatment by diagnostic-related group is in the pipeline (see below). Hospital doctors earn a salary, with a minimum salary set in 2015 at 2.4 times the average wage of the economy in the case of specialists.

The prices of refunded pharmaceutical products are regulated by the Ministry of Health based on an average of the three lowest prices for the same product in EU countries. The average rate of co-payment for medicines is $14 \%$. Annual co-payments are capped for pensioners, the disabled and children. 
Pharmacies, testing laboratories and around $90 \%$ of out-patient care providers are private. Some specialists in the out-patient sector are employed by the hospitals. A little under half of all hospitals are public, but they account for $55 \%$ of admissions, because they include the major establishments, university hospitals, specialist medical centres and all psychiatric hospitals. Public hospitals are also those that have the biggest deficits.

To respond to this need, the Slovak Republic has adopted several health-policy reforms since the mid2000s, which, however, pitted proponents of a market-based health system and regulated competition against supporters of a system of public provision and insurance. These developments demonstrate the lack of consensus on the best structure for the health system and can be seen in its current organisation.

Many of the changes to the health-care system over the last 13 years have undermined its efficiency and made it less fair. The increase in health spending, especially private spending (co-payments) induced by the 2004 Zajac reform hit the poorest families most (Kiss, 2007). This reform also led to a marked increase in the management costs and profits of the private insurers without any improvement in health outcomes (Filko et al., 2012). These developments, combined with a lack of equal distribution of information for policyholders on insurer performance and weak regulation, which encourages riskselection strategies, rather than healthy competition between insurers and providers, have reduced the system's efficiency. Measures that were subsequently adopted have corrected many of these shortcomings by reducing and capping co-payments, for example, and refining the formula for risk-compensation. However, the weak pricing regulation shows that the state hospitals do not effectively exercise their leverage against the health insurers when negotiating process. This lack of bargaining power of the hospitals against insurers results in efficiency losses. The major changes in the organization of health insurance companies proposed in reaction to the regulated competition introduced by the Zajac reform, with attempts to prevent health insurance companies from transferring profits generated from public funds to their shareholders in order to preserve the public nature of the Slovak health insurance system, have failed to meet their objectives for legal and financial reasons (Box 1). Yet, the authorities are still considering these reforms.

The way health insurance is currently organised, as a result of these developments, combines the drawbacks of systems incorporating some features of regulated competition with those of systems based on a single public insurer without harnessing their advantages. The structure of the system resembles that of Israel, Switzerland, the Netherlands and Germany, where competition between insurers improves efficiency and health-care supply provides targeted responses to the needs of different users. In the Slovak Republic, there is no market in the public health insurance system. The legal treatment covered by healthcare is so extensive in all respects that health insurance companies have little room to compete, which does not change anything of its non-economic nature. The three health insurers cannot easily differentiate their offerings. Insurance premiums (i.e. contribution rates) are fixed, and there is no market for supplementary health insurance because there is no clear definition of the content of the basket of basic services. The requirement that insurers sign contracts with all public hospitals whatever their efficiency further restricts their room for differentiation. Moreover, the sector is dominated by the public insurer, which covers two thirds of the population. The result is that its decisions concerning the remuneration of health-care providers strongly affect its rivals. This loss-making company also enjoys the state's implicit financial guarantee, which weakens its efforts to improve efficiency and further distorts competition. The elements of competition and profit orientation present in the Slovak system of compulsory health insurance should be considered to pursue the prime objective of encouraging the insurance companies to operate in accordance with the principles of sound management in the interest of a proper functioning of that social security system, thereby contributing to ensure that the social and solidarity objectives of that system are attained. The Slovak health-care system is thus of a hybrid nature between a competition-regulated model and a single public insurer system, with management costs higher than those normally seen in a singlepayer system (Figure 13). The government's program statement states that the limitation of profit should be done in accordance with the law of the Slovak Republic (i.e. the Constitution of the Slovak Republic and the international legal obligations of the Slovak Republic) as well as EU law. Moreover, the state has no 
direct control over the entire care chain, including management and costs, as it would in a centralised system.

Figure 13. Health administrative spending by type of healthcare system ${ }^{1}$

\section{Share of total health-care expenditure ${ }^{2}, 2014$ or nearest year}

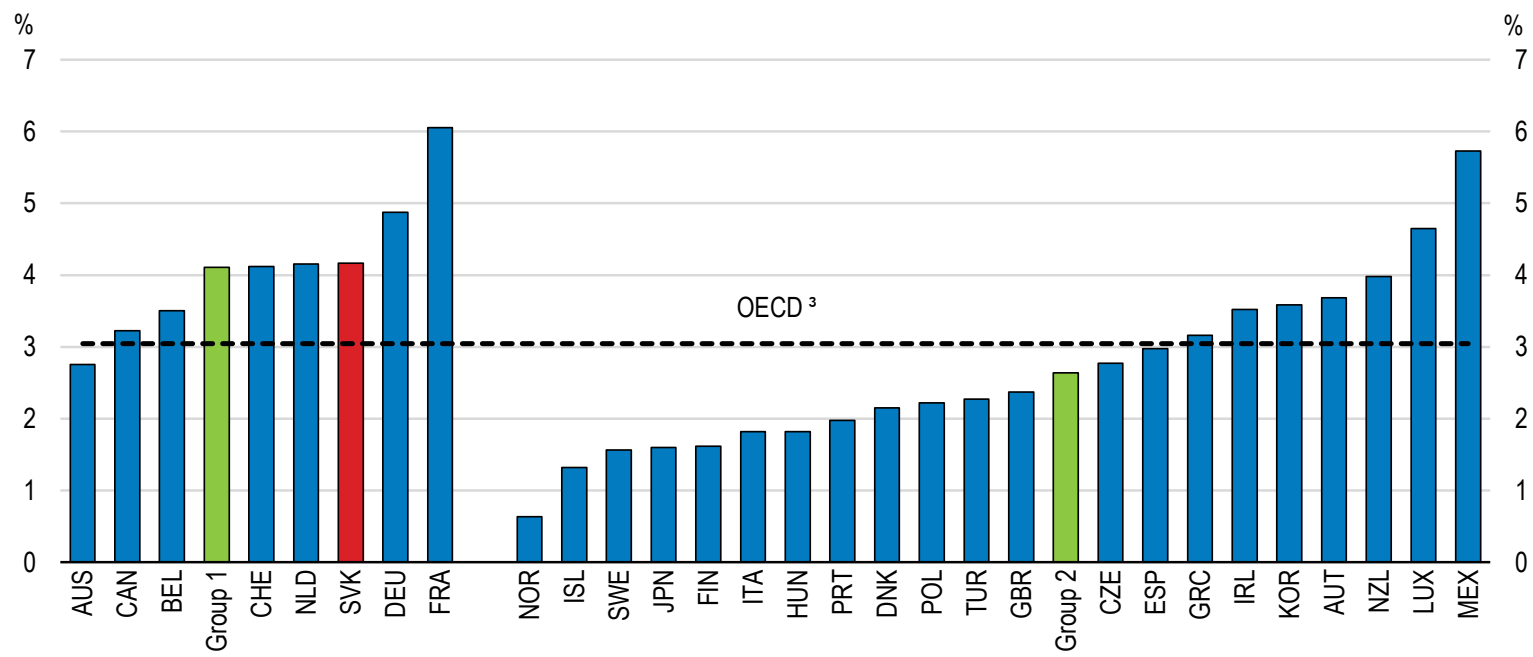

1. Group 1 includes countries with a high reliance on private health insurance and Group 2 mainly includes countries relying on public provision and public insurance.

2. Excludes investment.

3. Unweighted average of the data shown for Group 1, Group 2 and OECD.

Source: OECD (2016), OECD Health Statistics (database) and OECD (2010), Health Care Systems: Efficiency and Policy Settings.

The available research suggests that there is no single best health-care model: the choice of model depends on decisions dictated by social preferences (OECD, 2010). But the organisation of the healthinsurance system does have to be consistent, and seen in this light, the operation of the Slovak system would benefit from clarification between a system based on regulated competition or public insurance and provision. This is complicated by the lack of public consensus over the choice of model, limiting the potential efficiency gains from settling the issue. However, even if conditions are not met for making this decision, there is still plenty of room for improvement, both in terms of reducing operating costs and improving the quality and fairness of the supply of medical services and long-term care. The institutions and regulations seem to have contributed to a faster increase in public health spending in the Slovak Republic than in other OECD countries between 2000 and 2011 (de la Maisonneuve et al., 2016). Aware of the need to improve health outcomes, especially for vulnerable groups, while keeping spending under control, after the 2016 election the new Slovak government has introduced 26 reform projects, which aim to address several of the deficiencies of the health care system, as discussed below.

\section{Modernising hospital management and services}

There is a case for rationalising hospital care, which is beset by efficiency problems that aggravate the financial difficulties affecting hospitals, whose resources are limited by international standards (Figure 11, Panel B, above). The sector's operational shortcomings are highlighted first by poor control of procurement spending. Public procurement procedures are deficient, despite the introduction of an e-procurement system for these contracts in 2010 (OECD, 2014). The most expensive medical equipment, such as MRIs, scanners and x-ray machines, which account for $55 \%$ of total hospital purchases, are not covered by this 
system because of their high costs, and these purchasing decisions are not only decentralised but also rather uncompetitive, with an average of 1.1 bids per contract (Zachar and Dancikavá, 2014). Other signs of hospital management failings are the high number of acute-care beds per capita and their low occupancy rate (Figure 14, Panels A and B). The excessive number of bureaucratic tasks required of providers is another source of inefficiency in the use of human resources.

Figure 14. Hospital care supply

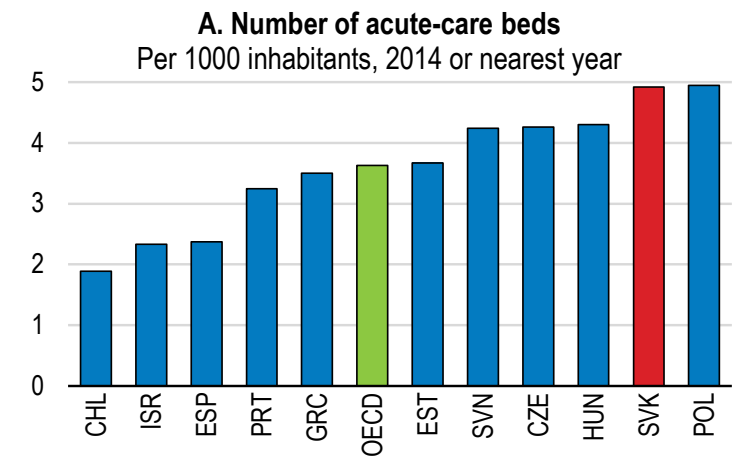

C. CT scanners, in hospitals

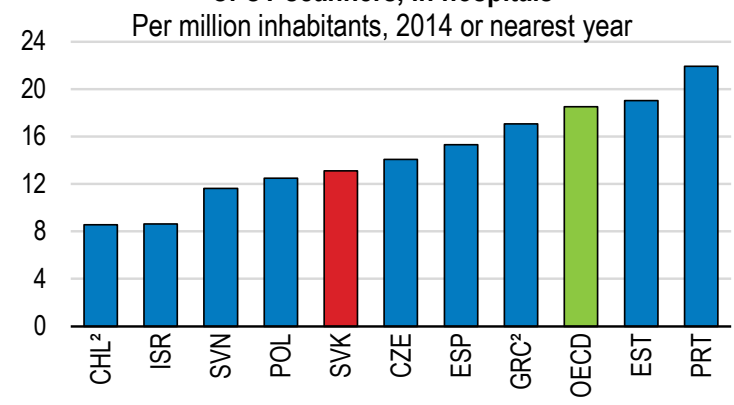

E. Number of professionally active nurses Density per 1000 inhabitants

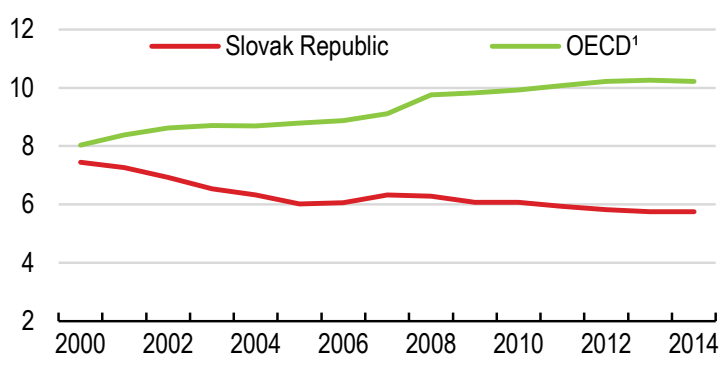

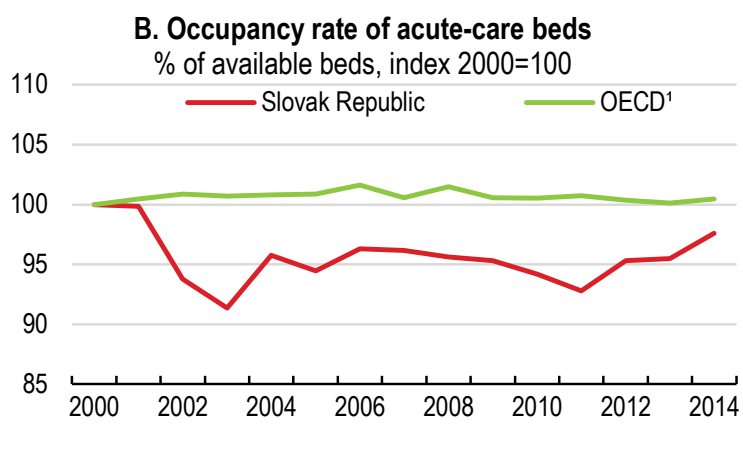

D. MRI units, in hospitals Per million inhabitants, 2014 or nearest year

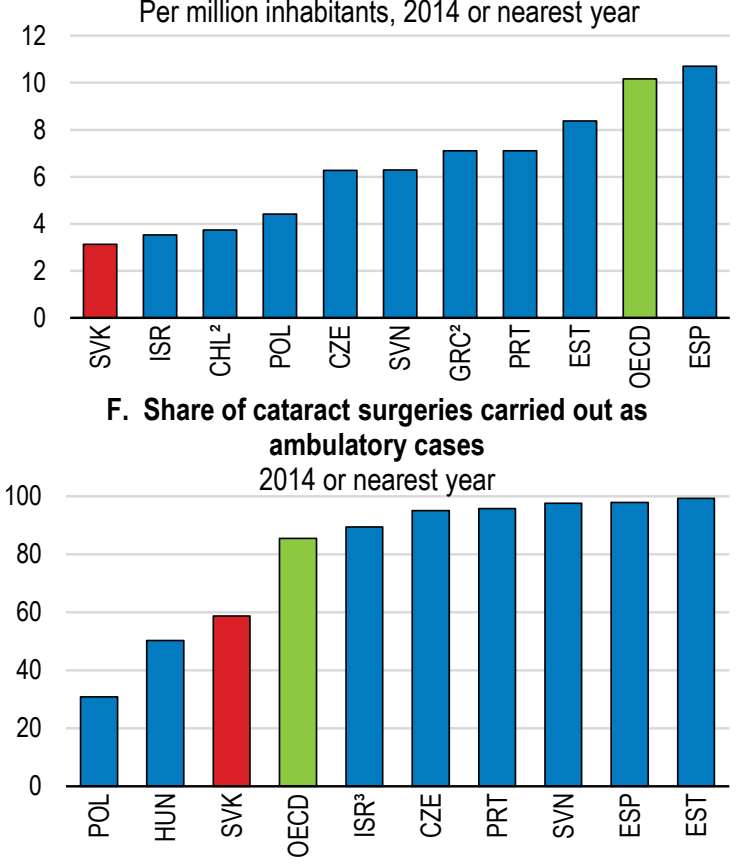

1. Unweighted average of data of the nearest available year.

2. 2013 for Chile and Greece.

3. 2013 for Israel.

Source: OECD (2016), OECD Health Statistics (database), OECD/EU (2016), Health at a Glance: Europe 2016: State of Health in the EU Cycle and OECD (2015), Health at a Glance 2015: OECD Indicators.

Because of this situation, the hospital sector is facing ongoing financial problems, with which the state has to deal periodically. These developments have led to a budgetary deficit, estimated at almost $0.3 \%$ of GDP per year on average between 2000 and 2011, whereas hospital debt still stood at 3/4 per cent of GDP in 2015. And they have also undermined the quality of health care. Hospitals are relatively underequipped in terms of advanced technologies (Figure 14, Panels C and D), and there are long wait times for many therapies. Hospital buildings have an average age of 42 years and are generally outdated and poorly 
organised, with care services housed in different buildings and a high risk of hospital-acquired infections (Poprocky, 2010; MoH, 2013; Spectator, 2016a). Hospitals lack resources for investment and maintenance, despite often urgent needs to modernise insulation, heating and operating theatres (Ineko, 2015; Pazitný et al., 2014), while nursing staff numbers seem inadequate. The number of nurses relative to the population is low compared with other countries and has been falling for around 15 years, unlike the average trend in the OECD (Figure 14, Panel E). According to the president of the Slovak nurses' union, the health-care system lacks 12000 nurses (Spectator, 2016b), a number which does not seem overestimated, since bringing the nurse density per thousand inhabitants to the OECD average level would require about 21500 more professionals.

These problems have many different causes, including an inadequate and poorly supervised financing system. Until 2015 public hospitals were not required to keep transparent accounts (Zachar, 2013). It was decided in 2011 to finance hospital care based on prices for treating diagnostic-related groups (DRGs), but this has only started to be put in place in 2017. Hospital funding by the insurance companies was therefore based on prices for medical procedures, which can differ widely from their effective cost, since they rely on self-assessment of therapies by the hospitals according to a broad classification. As a result of these price distortions, resources have been misallocated as hospitals attempt to find patients with "profitable" diseases, even if they could be treated on an out-patient basis, such as with cataracts (Figure 14, Panel F) (Pažitný et al., 2014).

The political nature of hospital director appointments - they are usually replaced after every election and the moral hazard engendered by the state's regularly paying off hospital debt do not encourage the search for efficiency and reforms. To make hospitals work better state intervention must be consistent, given the obstacles to overcome and the difficulty in implementing some measures. One such measure is the rationalisation of the hospital network, meaning closing establishments that are too small, a move generally opposed by local authorities. Efficiency and hospital management would also benefit from a more flexible system for setting pay, including a variable part related to the hospital's performance in order to incentivise staff to adopt new working methods. A growing number of OECD countries are including some kind of performance variable in doctors' pay packages (OECD, 2016a).

Reforms have been implemented to solve some of these problems and cut hospital deficits. The finances of all public hospitals were audited in late 2015, paving the way for five-year plans to rationalise spending. The hospitals' plans include a reduction in the number of acute-care beds, half of which will be converted to long-term care beds. In June 2016 steps were taken to re-examine the outsourcing contracts of some hospital activities, in particular with the replacement of private by public pharmacies on the hospital premises, so as to save financial resources (Adamovsky, 2016a). Some measures have also been taken to rationalise the management of public procurement: a reference price list for standard hospital supplies has been drawn up, and cost-effectiveness analyses have been introduced for the most costly and complex equipment. The adoption of this system in late 2015 is too recent for a performance assessment, but the Ministry of Health estimates that it could deliver savings of $15-17 \%$ on such items. After the 2016 election, the authorities have also prepared measures to modernise the emergency services and reduce the waiting times in hospitals through financing optimisation and better bed management.

Investment is set to rise, with the planned building of new hospitals, especially in Bratislava, to replace the old establishments that are being closed down (MoF, 2015). It is intended to modernise and transform several old establishments into specialized hospitals with more long-term beds. The authorities also want to rationalise the hospital network along geographic and specialisation lines, a process that should be made easier by the introduction of a DRG-based financing system in early 2017, after many years of planning. A well designed DRG system should not only increase the transparency and fairness of hospital funding but also help identify the most efficient establishments and incentivise them to further increase their efficiency. 
To be fully effective, however, these measures must be implemented carefully (Annear and Huntington, 2015; Shah et al., 2015). The authorities will implement the system gradually, which is helpful as it gives the hospitals time to adjust. In 2017, the first implementation year, he Ministry of Health will use hospital specific reference price systems for treatments, because there are wide gaps between hospitals, and there will be a convergence of these reference price systems over the next five years towards a single national system. There will also be a gradual increase of the proportion of DRG payments in hospitals' total revenues as this share will be no more than $2-5 \%$ in 2017. To promote efficiency gains and bring costs down, prices will indeed have to gradually converge, and DRGs will need to play play a bigger role in hospital revenues following a transparent process designed in close consultation with the insurers and the hospitals. Their engagement is crucial to the success of this reform. To this end, it would be desirable to set a clear timetable for its implementation, which could take until around 2020 according to the authorities, in order to focus the rationalisation efforts of health-care providers. Consulting with the insurers and hospitals would also be useful in planning the adjustments that are often needed to take account of some cost gaps beyond the hospitals' control, such as those linked to different labour costs between rural and urban areas and the presence of underprivileged communities. It is also important to monitor implementation closely, prevent hospitals cutting costs too fast to the detriment of the quality of care and carry out audits to ensure that services are being correctly coded, with clear penalties as a deterrent against fraud (Shah et al., 2015).

The authorities should also centralise hospital procurement as much as possible at the level of the Ministry of Health in order to reduce its cost. Alternatively, they could consider creating an independent agency responsible for monitoring hospital procurement management.

Professionalising hospital management would be another welcome development, which could be achieved, for example, by requiring the Ministry to appoint hospital directors solely from a list of candidates preselected on the basis of their professional capacity. In this regard, the creation since November 2016 of new supervisory bodies to oversee the state hospitals and emergency services and control their activity and budget is a welcome step. Improving the managerial skills of the heads of hospital departments, with special training designed for these doctors, could also have a positive efficiency impact.

Having enough nursing staff is a crucial factor in ensuring that hospitals perform well, but low pay and difficult working conditions, which were the cause of social protest movements in late 2015, imply few people are attracted to the profession. Despite pay increases since 2012, nurses still earn less than the economy-wide average salary and less than the OECD average in relative terms (Figure 15), despite a workload that is relatively high owing to their lower numbers. This explains why numerous Slovak nurses work abroad, mostly in Germany, Austria and the Czech Republic. Paradoxically, the number of newly trained nurses is higher than the OECD average. Since these courses are entirely state-funded, it appears that the public money invested in their education generates less of a return for the Slovak health system than for those of the country's main European partners, all of which suggests a need for further increases in nurses' pay, better working conditions and a more attractive scope of nursing work with a more developed content and more advanced tasks. The authorities are aware of these difficulties, and the creation in June 2016 of a new nursing department at the Health Ministry illustrates the emphasis put by the new government on addressing these issues (Spectator, 2016c). 
Figure 15. Nurses related indicators

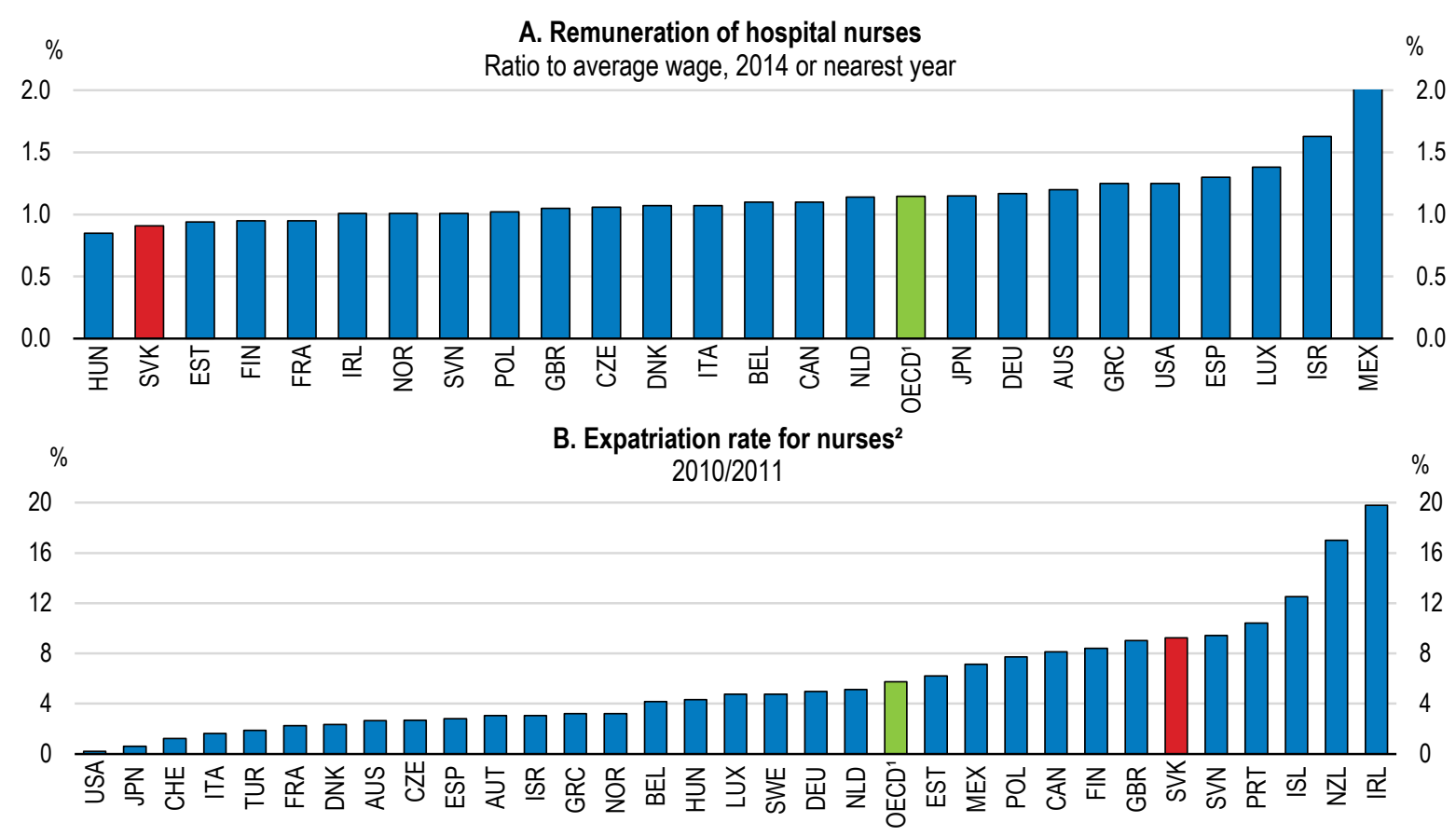

C. Nursing graduates

Per 100000 inhabitants, 2014 or nearest year

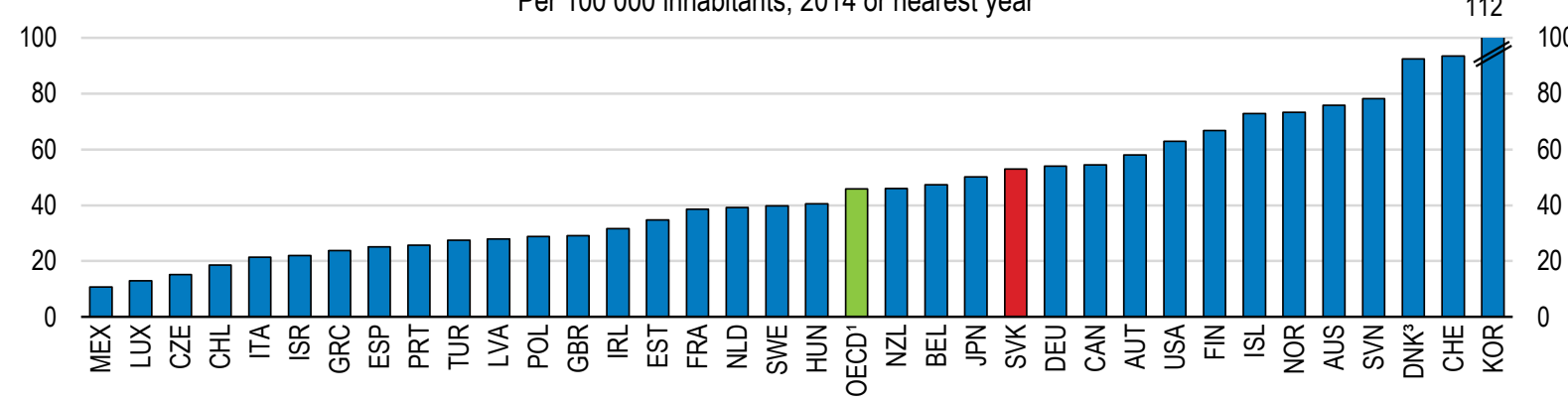

1. Unweighted average of the data shown.

2. The destination countries refer to OECD countries only.

3. In Denmark, the number refers to new nurses receiving an authorisation to practice.

Source: OECD (2016), OECD Health Statistics (database) and OECD (2015), "Expatriation rates for doctors and nurses, 2010/11" in International Migration Outlook 2015.

\section{Improving the efficiency and quality of primary health care}

Solving the efficiency problems of the primary-care sector is one of the government's top priorities. Operational difficulties in this sector - poor screening and late treatment of pathologies such as cancer, high blood pressure and cardiovascular diseases - are fuelling the country's high level of amenable mortality and the failure to achieve any progress in recent decades (Figure 16). One of the keys to improving results is a sufficient number of motivated, well trained medical staff, both GPs and specialists, evenly distributed across the country to provide good access to care for the whole population. It is also important to ensure a country-wide supply of primary-care physicians that meshes seamlessly with hospitals, clinical protocols and disease-management strategies based on best medical practice. 


\section{Figure 16. Mortality from selected diseases}

2014 (or nearest year)

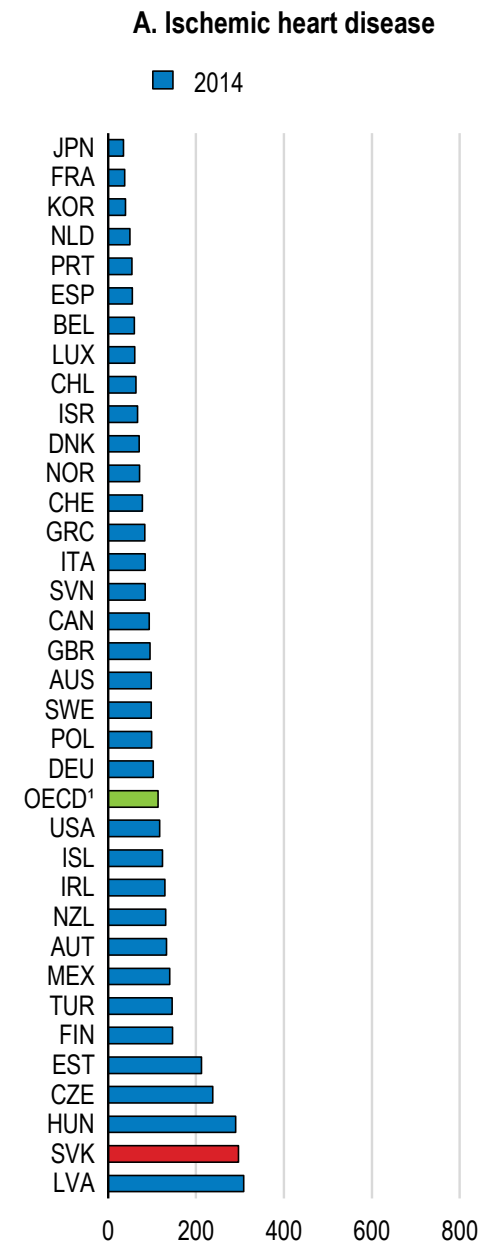

\section{B. Cerebrovascular disease}

$\square 2014$

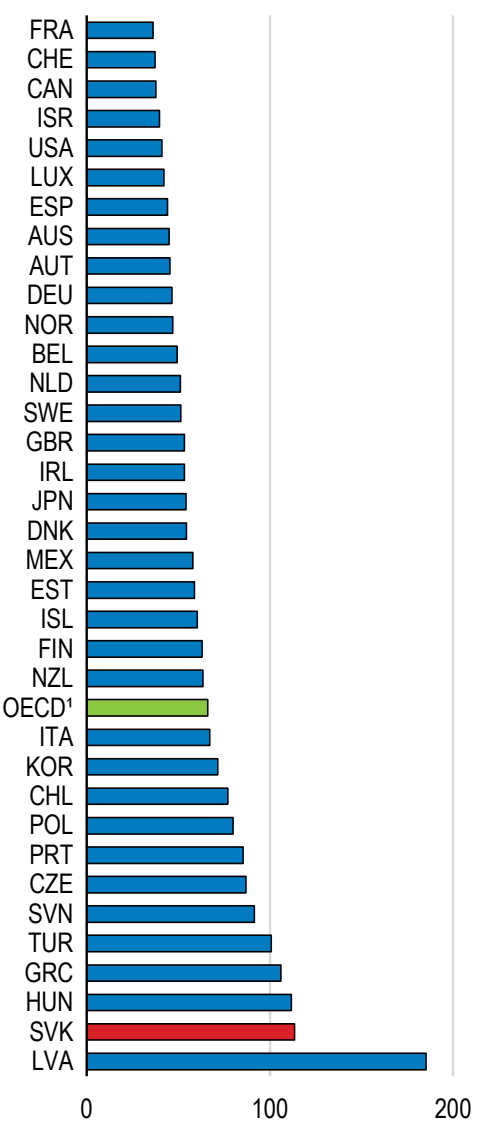

C. Cancer

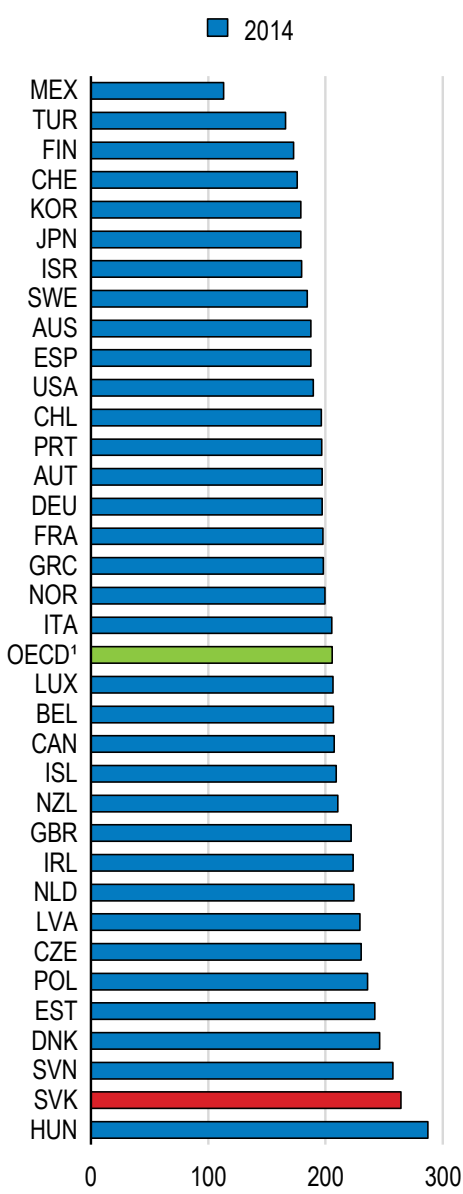

1. Unweighted average of the data shown.

Source: OECD (2016), OECD Health Statistics (database).

The Slovak Republic has enough doctors per capita, spends a relatively high share of health outlays on prevention and has a high vaccination rate (Figure 17). Yet, the primary-care system exhibits several shortcomings (WHO, 2016). Doctors are unevenly distributed across the country, with a greater imbalance between urban and rural districts than in most OECD countries (Figure 18). These disparities are of greatest concern in general practice and paediatrics, given the gatekeeper role played by these doctors for out-patient care. In some areas and for some communities, shortages cause accessibility problems, including for people suffering from chronic diseases. 
Figure 17. Primary care indicators
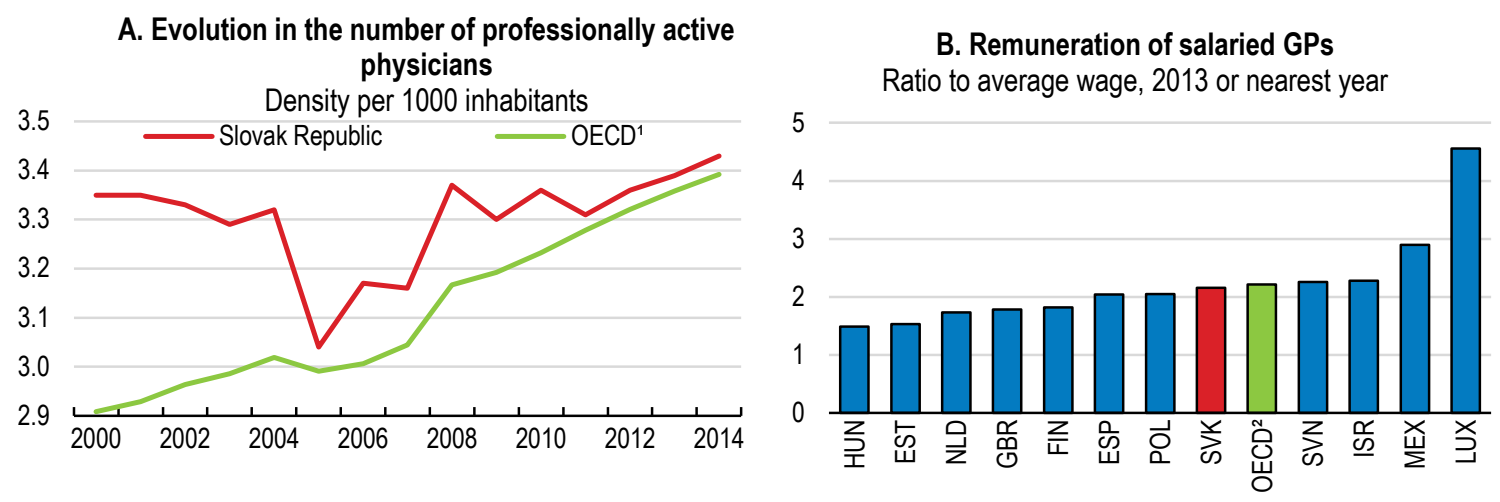

C. Spending on prevention and public health services

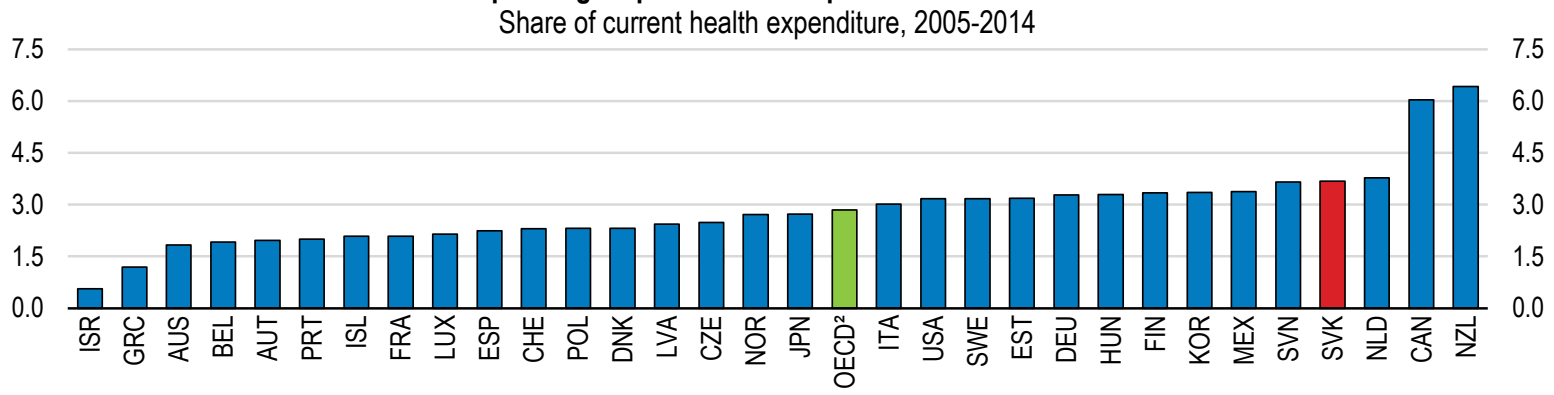

D. Vaccination rates ${ }^{3}$

Percentage of children immunised, 2014

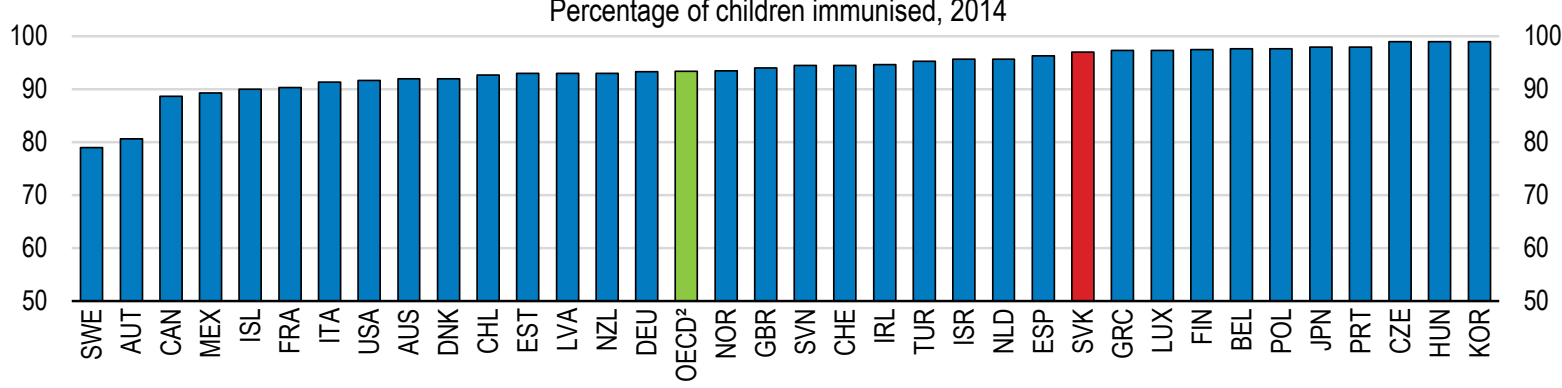

1. Unweighted average of data of the nearest available year.

2. Unweighted average of the data shown.

3. Unweighted average of vaccination rates for diphtheria, tetanus, pertussis, measles and hepatitis B. For Denmark, Finland, Hungary, Iceland, Japan, Norway, Switzerland and United Kingdom, average of diphtheria, tetanus, pertussis and measles.

Source: OECD (2016), OECD Health Statistics (database).

There are fewer doctors in general practice than in other fields (Figure 18), which pushes up the number of consultations each undertakes and reduces the time they can spend with each patient. Because general practitioners are paid by capitation rather than the services they deliver to a patient, they have an incentive to increase the number of enrolled patients, but also to reduce the number of services provided to each of them $(\mathrm{OECD}, 2016 \mathrm{a})$. Moreover, the legal restrictions on their ability to prescribe certain medicines undermine the effectiveness of their role in filtering and detecting diseases of at-risk patients. GPs are not allowed to prescribe almost $20 \%$ of available drugs, such as those used in cardiology, even though they are qualified to do so (these drugs can be prescribed only by specialists). There is no coordination with specialists in following standard clinical protocols and no adequate management of many minor health issues by GPs, and available estimates suggest that almost $80 \%$ of consultations result in a 
referral to a specialist, which is very high by international comparisons and implies little use of GPs' gatekeeping function (MoH, 2013; O'Donnell, 2000; Ringberg et al., 2013). This may be an overestimate, but there is no doubt that the out-patient workload is unevenly distributed between GPs and specialists, with an excessive number of specialist consultations. And, as mentioned above, specialists tend to ration this type of care when their monthly budget cap has been reached. Finally, the remuneration system for specialist care is based on a catalogue of procedures that has not been properly updated for more than a decade.

Figure 18. Physician density and activity

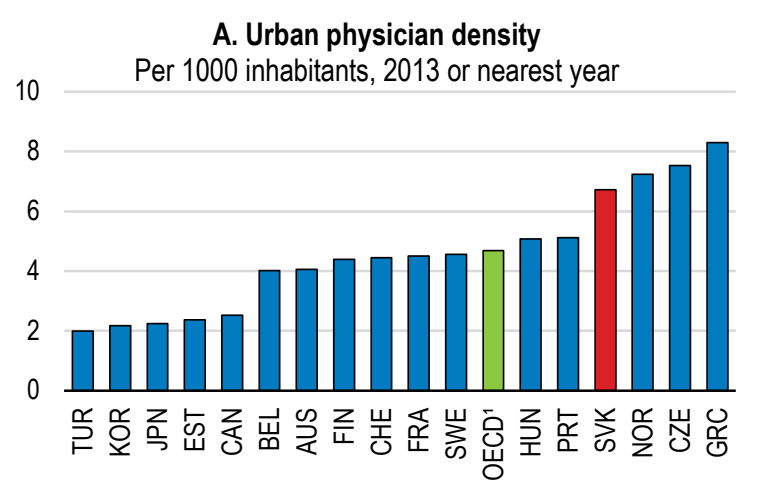

C. Specialists as a share of all doctors ${ }^{2}$ 2014 or nearest year

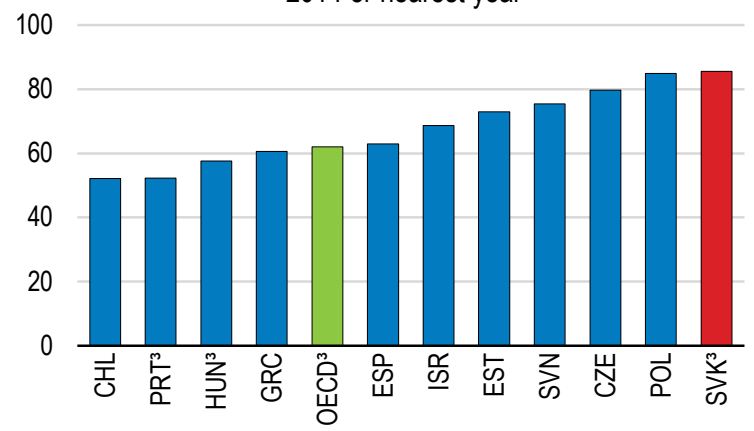

B. Rural physician density Per 1000 inhabitants, 2013 or nearest year

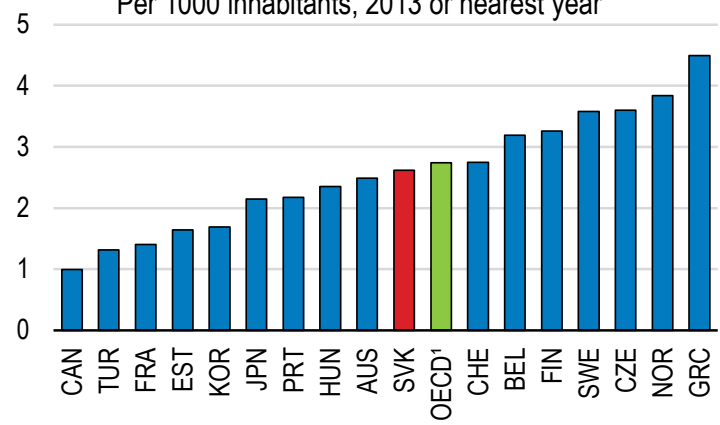

D. Number of physician consultations Per inhabitant, 2014 or nearest year

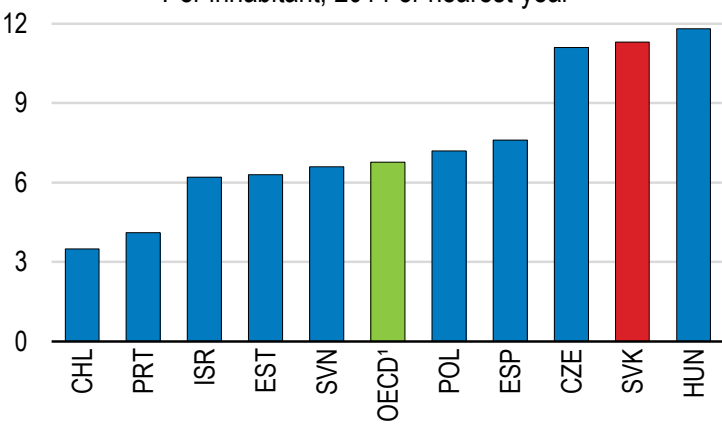

1. Unweighted average.

2. Specialists include paediatricians, obstetricians/gynaecologists, psychiatrists, medical, surgical and other specialists.

3. 2010 for Hungary and 2007 for Slovak Republic. Unweighted average of data for OECD countries for 2014 or nearest year. In Portugal, there is some double-counting of doctors with more than one specialty.

Source: OECD (2016), OECD Health Statistics (database), OECD (2015), Health at a Glance 2015: OECD Indicators, OECD (2013), Health at a Glance 2013: OECD Indicators, and Slovak Medical Chamber.

These difficulties will worsen in the future as physicians age. The average age for doctors is close to 50 , and the proportion of doctors aged over 55 exceeds the OECD average (Figure 19). GPs and paediatricians are even older, with an average age of 56-57 measured across the country, peaking in some districts at 63 for GPs and 68 for paediatricians. A high proportion of doctors are therefore close to retirement, raising the question of how to replace them, especially the relatively low number of gatekeeper doctors. 
Figure 19. Age structure of physicians
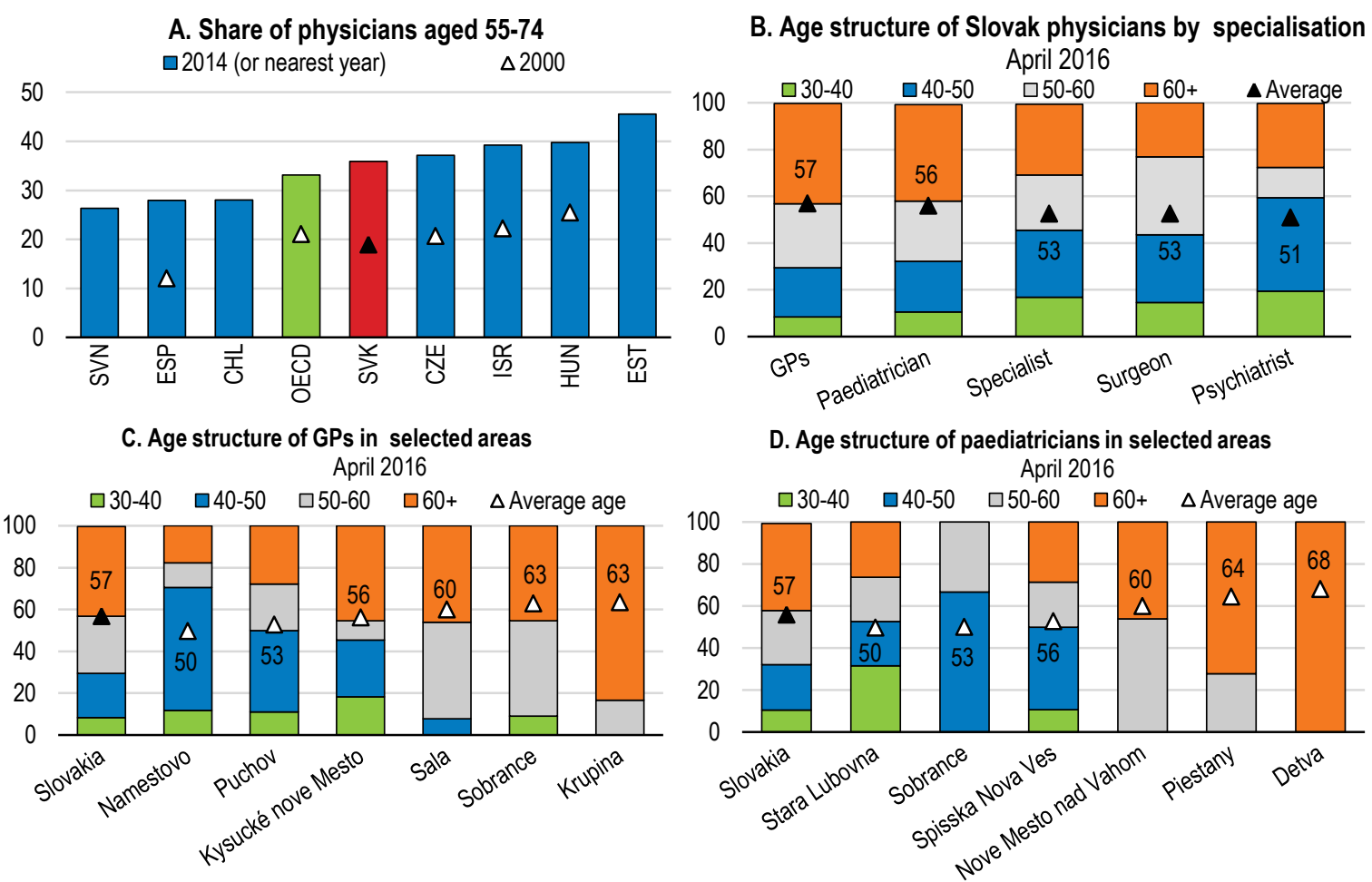

1. Unweighted average.

Source: OECD (2016), OECD Health Statistics (database) and Slovak Medical Chamber.

That the physician workforce is so old and the number of GPs so low has many causes. Slovak medical schools are not constrained in the number of doctors to be trained in each medical branch, and young doctors do not find general practice very appealing, which may be partly due to the restrictions imposed on their activity, as mentioned above. The capitation system also makes it hard for young GPs to set up a successful private practice unless they buy or take up the clientele of a retiring doctor. And even that is not particularly appealing, if the practice is in an isolated rural district. In contrast, emigration is often attractive for young doctors, given the ease of mobility within the European Union. The share of doctors trained in the Slovak Republic and practising abroad was 19\% of the total number of Slovak doctors in 2014, which is high in international comparison (Figure 20). This brain drain is more pronounced among medical graduates than among those from other fields of study. It is estimated that about $20 \%$ of students who completed their medical studies between 2012 and 2014 left the country to practice abroad, essentially in the Czech Republic, Germany or Austria (see OECD, 2017c). This amounts to a waste of public money, since medical school and nursing training are entirely funded by the state. 
Figure 20. Emigration rates of doctors ${ }^{1}$

Percentage of total number of doctors, 2014 or nearest year

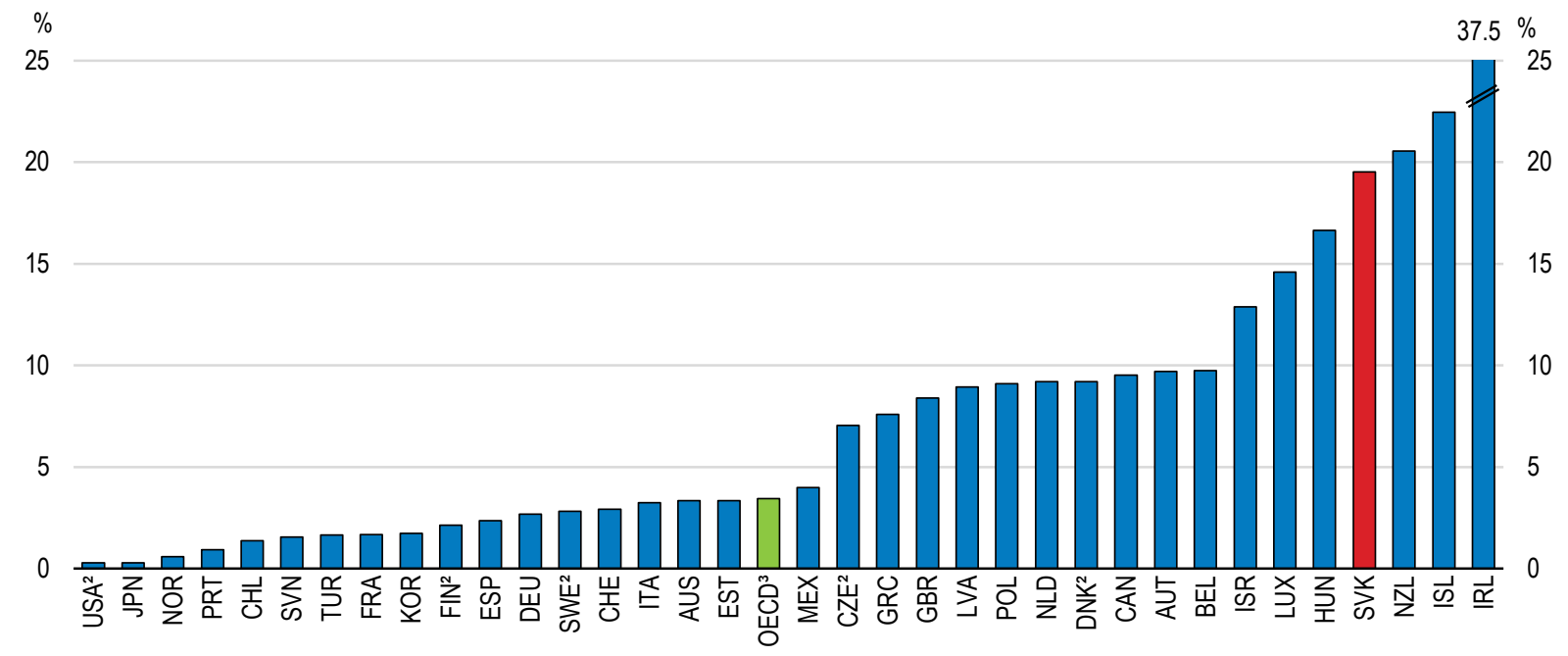

1. Share of doctors trained in the country, but working abroad.

2. 2013 for Czech Republic, Denmark, Finland, Sweden and United States.

3. Unweighted average.

Source: OECD (2016), OECD Health Statistics (database) and Statistical Office of the Slovak Republic.

The authorities have taken several steps to improve primary care and solve the problems related to doctors' demographics. Doctors' pay has been increased to reduce emigration. In 2014 they earned an average of $43 \%$ more than in 2009 , and their level of pay compared with the economy-wide average was similar to the OECD average (Figure 17, Panel B, above). A Residential Programme has also been developed since 2014 to increase the attractiveness of general practice and paediatrics and to make the gatekeeper role more effective. The degree course was shortened in this Programme, and a greater amount of work experience for students built into the syllabus, including internships with doctors in private practice. Most significantly, GPs' skills were upgraded, including in the domains of pre-operative examinations and the treatment of patients suffering from chronic diseases, such as diabetes. A third strategy for reform, launched in 2008, was to expand e-health, with the introduction of electronic personal health records and e-prescriptions. These changes initially planned for 2017 have been postponed to 2018 for e-prescriptions and 2021 for the complete diffusion of electronic health cards. They are costly (EUR 250 million, or $0.3 \%$ of GDP), but they should deliver improvements in the way providers interface with patient follow-up and reduce the number of medical examinations and administrative costs.

It is too early to assess the success of the Residential Programme, but initial results suggest that it should attract enough students to replace the GPs scheduled to retire in the coming years, according to the Ministry of Health. But aiming to improve and rebalance the primary-care supply between GPs and specialists by merely preventing a fall in the number of gatekeepers looks insufficiently ambitious. The number of these doctors should be increased to build up the resources needed for screening programmes and the early management of diseases that pose a high risk to health. The authorities could achieve this by exercising greater control over the number of doctors trained per medical branch, as in most other OECD countries (OECD, 2016b). This would be useful both for the purposes of training enough GPs and paediatricians and for increasing the availability of some specialist care for which demand is likely to rise because of the ageing population. This shift could also usher in measures to distribute doctors more evenly across the territory: the authorities could, for example, restrict authorisations for doctors in very well served areas and introduce financial incentives (such as higher capitation payments) for them to move to areas lacking doctors (OECD, 2016b). Another reform option to consider is the widening of nurses' competences and responsibilities to perform some of the basic tasks of the GPs. 
The improvement of GP and paediatrician training via the Residential Programme and the extension of their fields of competence should also improve primary-care quality. But the reform should go further and eliminate all restrictions on the competence, prescription writing and practice of gatekeeper doctors. Such restrictions are rare in OECD countries, given the responsibility doctors have to their patients, and they seem to respond more to the aim of partitioning and protecting the work of specialists than the promotion of public health. What is needed is increased care co-ordination between GPs and specialists. This could be promoted by speeding-up the diffusion of the electronic health card and the development of poly-clinics, which currently supply only $5 \%$ of total Slovak outpatient care, most of which is provided by independent private doctors. Bringing more GPs and specialists together in poly-clinics, as is the case in Israel, for example, would encourage them to interact and improve patient monitoring and case management.

It would also be advisable to change the way doctors are paid. This is overwhelmingly based on capitation for GPs, which keeps a tight rein on spending but does not promote care quality. Revenues based on this system account for over $90 \%$ of GPs' total incomes. Although some positive steps have been recently made by the government to better specify the payments and co-payments between physicians and patients, greater diversity of remuneration would help to correct the shortcoming, with more fee-for-service payments and the introduction of performance-related pay. The latter can take various forms and is being tested in several countries. It aims to link doctors' pay explicitly to precise targets in terms of results, coverage or care quality, by improving co-ordination among service providers, for example. This kind of pay does not normally cause a sudden and dramatic breakthrough in care quality or effectiveness, but it is a useful tool, which an increasing number of OECD countries are employing to achieve their health objectives through improved incentives (Cashin et al., 2014; OECD, 2016a). The use of bundled payments, for example, to several medical providers for the improved management of patients suffering from a chronic disease such as diabetes, is increasingly widespread and could be an interesting option (Struijs and Baan, 2011; Struijs et al., 2012; OECD, 2016a).

The specialists' fee-for-service system with a capped budget should also be reformed. The authorities might consider the German model, where the price of services is adjusted when the number of consultations reaches a certain level: this could limit needless consultations and reduce the quantitative rationing of care that now takes place at the end of every month. The list of procedures on which their pay is based should also be updated, as planned by the authorities.

Moreover, queues and long waits for appointments - which rose further after the abolition in June 2015 of the option to make a co-payment to obtain an appointment - are frustrating for patients and have a non-negligible economic cost. The Health Ministry's decision to re-introduce in 2018 a fee to obtain an appointment is thus a step in the right direction, although it is accompanied by regulations limiting the use and revenues drawn by doctors for this service (Spectator, 2017). A simpler and probably more costeffective solution could be to encourage doctors to acquire a medical appointment booking system online as a standard service. Assuming that every hour spent in the waiting room by every person that has to take time out of work reduces the total number of hours worked in the economy by around 0.3 hours, the lost revenue would be equivalent to EUR 85 million, or $0.1 \%$ of GDP, valuing these hours at the average hourly wage. The time lost in waiting for an appointment with a GP may be between one and three hours, but it can be far longer for a specialist.

Finally, clarifying and rationalising co-payments for primary-care services, which lack transparency and are confusing for the public, would also be welcome. To this end, the Ministry of Health care is introducing a more organized system of service payments with strong regulation and a public list of mandatory payments which will clarify the information at the patient level. 


\section{Pursuing efforts to bring down pharmaceutical expenditure and other ancillary health-care spending}

Reforms over the last decade have led to major progress in curbing pharmaceutical spending. As a share of GDP this spending has not fallen by much since 2003, but it has dropped from $40 \%$ to $26 \%$ of all medical spending (Figure 21, Panels A and B). This development was the result of a series of initiatives that aimed to contain both consumption in volume and prices of prescription drugs. Between 2003 and 2007, co-payments for patients were increased, from a low level compared with other countries, before being capped for some groups of patients in 2011 to reduce the regressive impact of this measure (Panel C). In 2008 the authorities set up degressive margins for pharmacists and their distributors when drug prices increase to reduce their incentive to sell costly medicines. A reference price system for pharmaceutical products was introduced in 2009, based on the prices in the European Union where they are the lowest, which put a brake on the increases in the average prices for reimbursed medicines (Panel D). A requirement for doctors to prescribe generics was also adopted in 2011 to further increase up-take of these products (Panel E).

\section{Figure 21. Pharmaceutical expenditure}
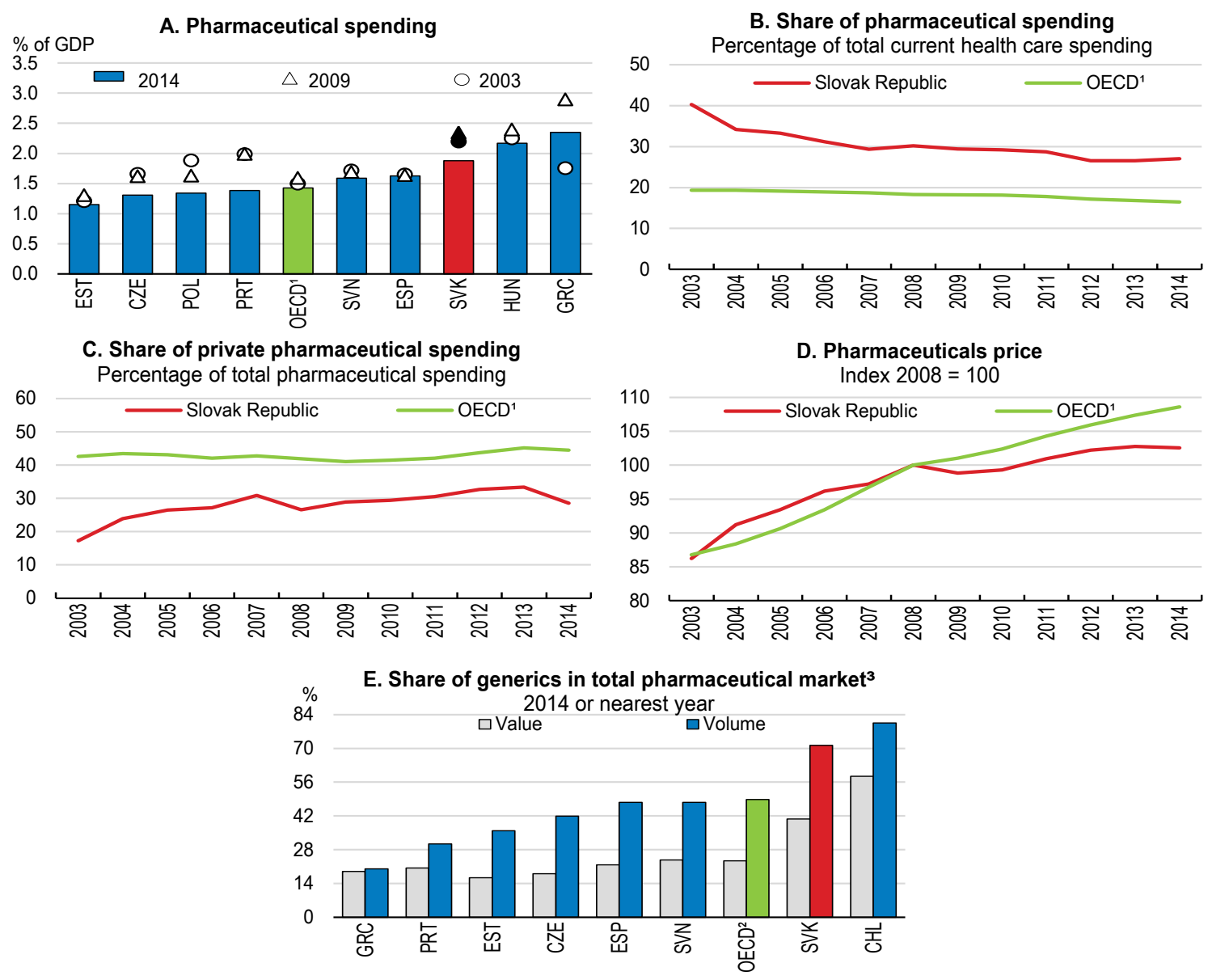

1. Unweighted average of data of the nearest available year.

2. Unweighted average.

3. Reimbursed pharmaceutical market for Greece and Spain. Community pharmacy market for Chile and Slovenia. Source: OECD (2016), OECD Health Statistics (database).

Although it has been brought under control, pharmaceutical spending is still difficult to manage. Total drug spending remains high as a share of GDP by comparison with the OECD average, and this situation 
reflects excessively high consumption volumes (WHO, 2016). The measures taken have pushed prices down to a low level relative to other countries, and it would be hard to cut prices any further. Because of their low cost, Slovak medicines tend to be re-exported to other European countries, which can occasionally lead to shortages for some products, although some recent measures announced by the government should help to better prevent these shortages (Šterbová, 2015; Szalayová et al., 2014, Adamovsky, 2016b; Spectator, 2016d). Moreover, it may prove difficult for the Slovak Republic, as for other OECD countries, to maintain the improved level of spending control acquired in recent years (OECD, 2015b; Belloni et al., 2016). The range of speciality medicines that open new avenues for the treatment of diabetes, cancer and hepatitis $\mathrm{C}$, for example, has expanded considerably in the last few years, but these drugs are often costly, while demand for them is rising with the increasing incidence of chronic diseases linked to bad lifestyles and the ageing population. The consumption of medicines is five to eight times higher after the age of 65 than between 5 and 45 (OECD, 2015b).

Although spending control has improved for pharmaceuticals over the last 10 years, it has not done so for other patient medical services or for ancillary health spending. Since 2003 these expenditures have risen substantially as a share of GDP, and the figure is well above the OECD average (Figure 22). Spending has, for instance, risen sharply for ambulance services, emergency care and laboratory tests.

Figure 22. Other medical goods and ancillary health services

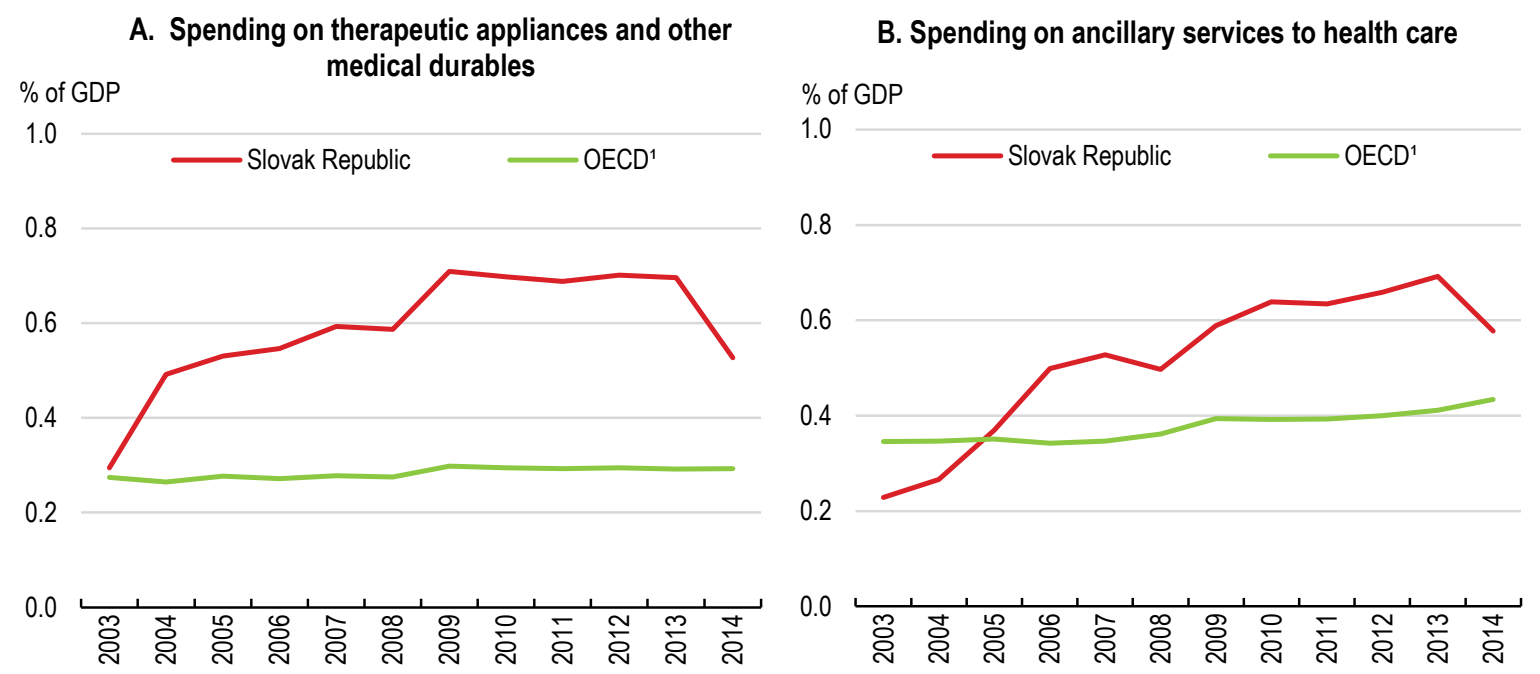

1. Unweighted average of data of the nearest available year.

Source: OECD (2016), OECD Health Statistics (database).

To improve control of spending on medical supplies, in January 2016 the authorities set up a reference price system based on average prices in the three EU countries with the lowest prices, akin to the current system for reimbursed medicines. The introduction of e-prescriptions as part of the tele-health development programme, planned for 2018, should improve control of the volume of spending on medicines. The new system should help health-care providers to better co-ordinate their actions and cut back on redundancy in prescriptions and overconsumption of medical supplies and services, which should also be easier to track. These are positive measures, but to make the e-prescription system more effective, it would be useful to back it up with public information campaigns encouraging patients to change their behaviour and their expectation that they should automatically receive a prescription at every consultation. 
It would also be wise to investigate spending on lab tests and patient transport with a thorough analysis of volume, price and geographical split. At first sight, it seems hard to justify ancillary health spending that is so high compared with other countries. The market for lab tests is highly concentrated, with the three main providers sharing three-quarters of the market. Insurers, led by the public company, should be encouraged to toughen their negotiations with the big medical labs over the cost of these tests, pointing to international price comparisons, for example. There also needs to be better control over lobbying by the dominant labs, which encourage doctors to increase prescriptions in exchange for rewards in cash or in kind. The pharmaceutical companies also engage in this sort of lobbying. In response the government requires all revenues paid to doctors by these firms to be declared to the tax authorities. Not much information about them is available, however, and the convoluted way these data are provided to the tax authorities makes their use difficult (Transparency International Slovakia, 2014), suggesting that their deterrent effect is too weak, and more transparency might be needed. More radically, the authorities could ban all "gifts" from pharmaceutical firms and testing labs to doctors, as the French have done.

It is also important to prepare for the probable emergence of new pressures on pharmaceutical spending: the rise in chronic diseases and the arrival on the market of innovative but costly new drugs. The potential rise in spending on new therapies is not necessarily a problem, if it improves the management of diseases (Lichtenberg, 2007). However, some drugs deliver significant benefits, while others offer only marginal improvements, whereas the cost of treatments is more often linked to the market situation (unsatisfied medical need, small target population) than to clinical and patient benefits (OECD, 2015b). Currently all new reimbursed drugs have to pass a cost-effectiveness test measured on the basis of the socalled quality-adjusted life year indicator. In principle, this test requires that the benefits of new medicines prolonging a patient's life should not generate additional system costs exceeding 35 times the average monthly salary per year of quality-adjusted life. In practice, however, this test seems to have not always been rigorously applied, because of insufficient transparency in procedures and conflicts of interest of members of the Expert Working Group on Pharmacoeconomics, which is in charge of such evaluations (Adamovsky, 2016c).

As recently recognised by the authorities, to address this issue it will be important to promote a more transparent and independent system for assessing performance in order to select and offer cover for those with a cost-benefit ratio that meets well defined standards. This is consistent with recent OECD work stressing the need to promote better regulations to ensure that the prices paid for innovative drugs or new medical technologies reflect their real-world health benefits (OECD, 2017b). Therefore, the recent creation of a health technology assessment agency by the Ministry of Health to analyse clinical and cost effectiveness and safety of new health technologies and drugs is a positive step. In this context it would be advisable to also improve the available information about pharmaceutical consumption in hospitals, which are the biggest prescribers of these costly therapies, to have a better view of the ongoing relevant trends.

The authorities could also encourage the development of drug therapy, based on standardised therapeutic procedures and prescriptions. One way of doing this might be to require that patients taking more than a specified quantity of prescription medicines attend a mandatory consultation with a clinical pharmacologist in order to assess whether the prescriptions are justified as well as potential interactions between various products. Last, although generics are already widely used in the Slovak Republic, there remains room for progress, and their mandatory prescription, which currently affects only those with one active ingredient, could be extended to all generic drugs with multiple active ingredients.

\section{Developing a long-term care strategy}

The supply of long-term care in the Slovak Republic is underdeveloped, mainly because of a lack of financing. Spending in this field is around $6.5 \%$ of total health spending, or $0.5 \%$ of GDP, which is half the OECD average (Figure 23, Panel A). Most of the supply consists of social support, and the medical system 
plays a fairly marginal role. Despite the limited resources devoted to this sector, the proportion of the over$65 \mathrm{~s}$ benefiting from long-term care is similar to the average for OECD countries (Panel B). The majority of services (around 60\%) is delivered through informal home care, generally by the beneficiary's friends or family, who receive a small financial allowance as compensation. Institutional care and residential services provided by professional careers, which account for around 30\% and 10\%, respectively, of total long-term care, employ relatively few people compared with other OECD countries (Panel C). The lack of in-home care capacity, which is vital for the most dependent people, means long waiting lists for places in stateowned institutions. Despite the absence of indicators for the quality of this care, such homes are widely perceived as sub-standard, because of a lack of financial and human resources (Vagac et al., 2014), and the cost of a place in a private home is generally very high.

Figure 23. Long-term care

2014 or nearest year unless specified
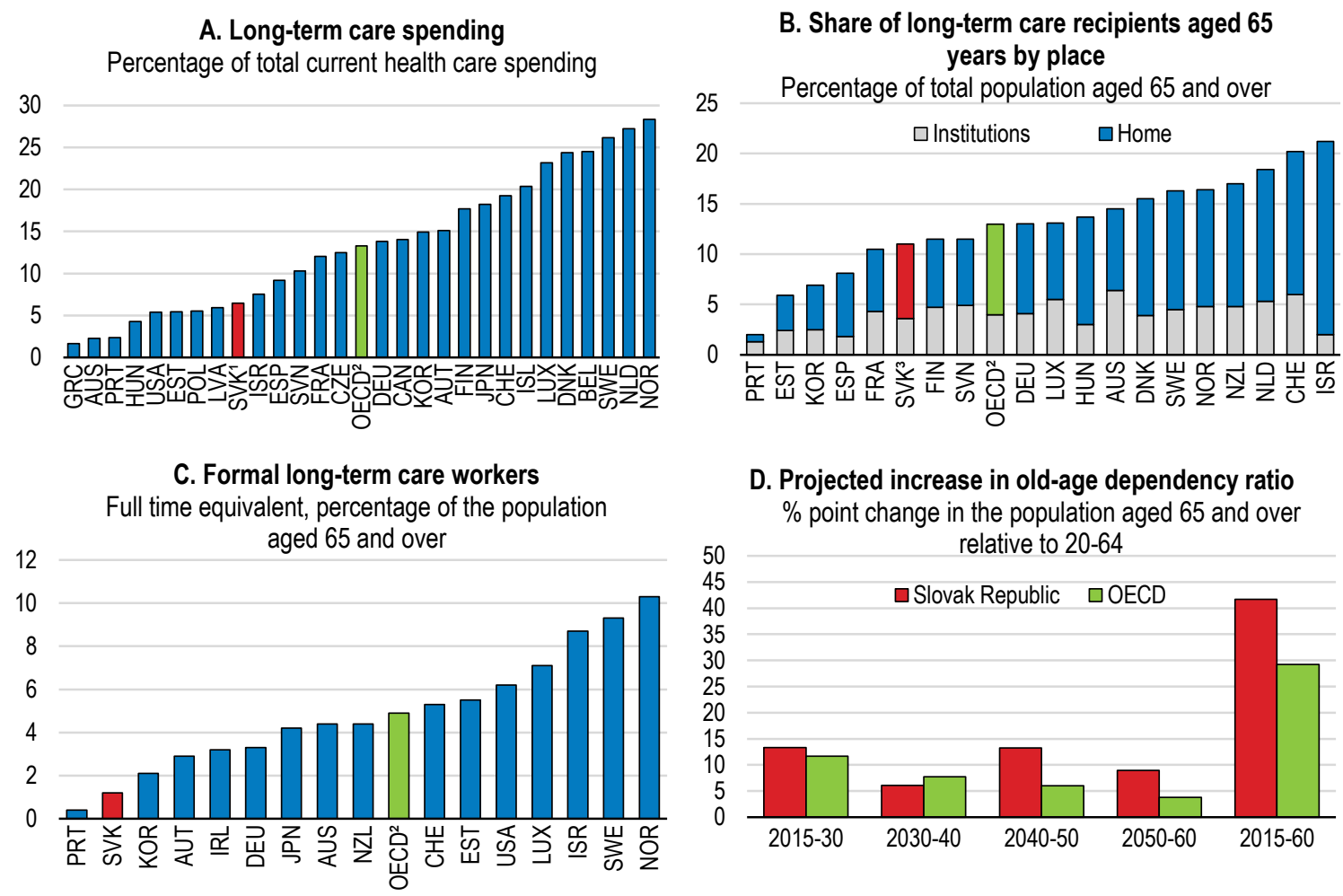

1. Data in 2013. It includes long-term care spending of EUR 344 million by the Ministry of Labour, Social Affairs and Family of the Slovak Republic. Data for the Slovak Republic include social spending and is not fully comparable with other countries.

2. Unweighted average of the data shown.

3. The number of long-term care recipients at home aged 65 and over is estimated on the basis of the total number of long-term care recipients at home.

Source: OECD (2016), OECD Health Statistics (database), United Nations (2016), World Population Prospects: The 2015 Revision (database) and Ministry of Labour, Social Affairs and Family of the Slovak Republic.

The fragmented organisation of the long-term care system complicates its management and use by beneficiaries. Administration and financing are shared between the Ministry for Social Affairs, the Ministry for Health, and regional and local governments. The health-insurance system contributes to the long-term care system by funding a specific list of only nine medical procedures. Social services include assistance in cash and in kind funded from various sources. Cash benefits allow dependent people to pay 
for home help from outside or within the family and are financed from the state budget. Care in kind delivered at patients' homes is devolved to and partly financed by city and regional authorities. Access to these services and cash benefits is means-tested and conditional on the applicant meeting certain dependency criteria. The multiple channels for aid, managed by different bodies, make the system opaque and difficult for users to navigate (Vagac et al., 2014); the bureaucracy involved in evaluating an elderly person's needs is drawn out and cumbersome, and the different kinds of aid are poorly co-ordinated.

The financing of the long-term care system is also badly prepared to cope with demand pressures expected in the coming years due to the ageing population. In fact, the chronic financing problems have been worsening since 2009 under the impact of the economic crisis and the budgetary restrictions imposed on regional and city authorities, difficulties that forced the central government to step in with occasional bail-outs to prevent the closure of some care centres. The beneficiaries of these services were also asked to contribute directly to their funding, which, given the low level of pensions, engendered social tensions. And these financial pressures will intensify with the acceleration of population ageing, which will be more pronounced than in many other OECD countries between now and 2030, and even more so between 2040 and 2060 (Figure 23, Panel D). Public spending on long-term care could increase from $0.4 \%$ to $1.1 \%$ of GDP by 2060, according to these projections (Table 2, above).

To cope with the expected rise in demand for long-term care the authorities will have to face the challenge of finding the additional resources they need, especially in terms of carers. It will probably be difficult to maintain the current structure of the care system, which relies mainly on informal care for dependent people by their friends and family, generally women. While this is not onerous for the public purse, such an approach reduces women's participation in the labour market and squanders their human capital. Moreover, formal jobs in this sector are poorly paid, despite difficult working conditions, and, as in nursing, a high proportion (an estimated 65\%) of carers trained in the Slovak Republic work abroad, mostly in Germany and Austria, where there is high demand for these workers (Nadazdyova et al., 2013; Vagac et al., 2014).

Reforms will be needed to improve the system and meet the rising demand expected in the coming years. This may require increasing the resources of regional and local administrations to boost the quantity and quality of care provision. An alternative solution could be the introduction of a mandatory dependency insurance, similar to schemes adopted in some other countries, including Germany and Japan. There is also a need for better organisation of the different kinds of social and/or medical assistance required by dependent people. This could consist of the creation of one-stop shops at the regional level with adequately trained personnel centralising access to information, simplifying the application process for the various services available and helping to co-ordinate the different long-term care providers.

As a general rule, it is important to help elderly dependent people stay at home as long as they can, since this is usually what they want and is less costly than a place in a retirement home. However, increasing and improving the supply of institutional care seems to be necessary, which will mean adapting the number of available beds to demand and making sure that care meets minimum legal quality standards. This might be achieved by transforming some existing acute-care beds and other facilities for which there is an excess supply into long-term care centres. Strengthening the supply of home care delivered by adequately compensated family members or properly trained professional carers also seems to be desirable. If not enough carers are forthcoming, the authorities could follow the example of other OECD countries and consider the regulated opening of this market to migrant workers, including those from outside the European Union (Vagac et al., 2012; Nádaždyová et al., 2013). Such a policy would require recognising the professional qualifications of these workers, who would also have to be trained to learn and understand the specificities of Slovak lifestyle and culture to ease their integration into Slovak society. 


\section{Promoting healthier lifestyles}

In addition to making the health-care system work better, the authorities also need to promote healthier lifestyles to improve the country's health outcomes. If Slovakia were to align itself with the European Union's most virtuous performers in terms of smoking, alcohol consumption, diet and obesity, estimates suggest that life expectancy could increase by almost four years (EC, 2015a). This would also bring significant economic benefits in terms of employment and productivity, even though the decline in medical costs linked to the reduction in disease induced by healthier lifestyles could be limited, since it would be partly offset by the extra spending seen with greater longevity and the higher medical costs associated with the elderly.

There are several factors, however, holding Slovaks back from healthier living. Relatively low prices for alcoholic drinks, which are taxed less heavily than in most OECD countries, influence both drinking habits - with particularly high spirits consumption - and fatal diseases, which are prevalent by international standards (Figure 24, Panel A) (OECD, 2015c). The situation is similar for male smokers, given relatively low tobacco prices (Panel B). Also, the consumption of fruits and vegetables is low (Panel C), and while the Slovak Republic does not struggle as much as the average OECD country with obesity, including among young people, the situation has deteriorated considerably since the mid-2000s (Panel D).

Higher excise taxes would reduce alcohol and tobacco consumption, thereby reducing the associated health problems. Taxing these items more heavily will not only help to change people's behaviour and reduce the mortality linked to drinking and smoking but is also likely to generate additional budgetary revenues. The recent cigarette tax increase, which increased their price by about $6 \%$, is thus welcome. The positive impact of these measures on health ought to be greater for the poorest parts of the population, who suffer the most from the negative consequences of alcohol and tobacco abuse (Sassi et al., 2013), since they are the most likely to adjust their behaviour in response to price increases, given their financial constraints. One potential barrier to further changes is the risk of increased smuggling of black-market alcohol and tobacco, if the higher excises lead to significant price differences with neighbouring countries. Working with them, since they share the same public health issues surrounding alcohol and tobacco, could be a way to harmonise taxation on these products and remove this barrier.

Specific taxation for some non-alcoholic food and drink should also be considered. The frequent consumption of high-calorie products, saturated fats, trans fatty acids, sugar and salt boosts the risk of obesity and disease. Raising their prices with tax levies can influence people's eating habits and promote healthier diets (WHO, 2015). Consumers are more sensitive to variations in the price of sweetened beverages than other foodstuffs (Marron et al., 2015; Sassi et al., 2013), which suggests that moderate taxes can have a significant impact on consumption without generating markedly regressive effects, especially if there are healthier untaxed alternatives. Drinking fewer sugar-sweetened beverages, which are more popular among young people in underprivileged communities, would also help reduce health inequality. Sugar taxes have recently been imposed in Denmark, Hungary, Finland, France and Mexico.

The adoption of healthier lifestyles is also of crucial importance in the Roma community. The poor general health of this population, especially of marginalised Roma living in segregated areas, is partly linked to their difficult living conditions, which have many causes, including significant poverty, challenges accessing basic infrastructure and, often, sub-standard housing (Figure 25). This situation is compounded by discrimination and the Roma community's distrust of official Slovak institutions, including doctors, which constrains the adoption of healthier lifestyles and improved hygiene standards, with negative health repercussions (Gati et al., 2016). Morbidity rates linked to infectious intestinal diseases (such as dysentery), respiratory diseases, viral hepatitis and scabies are high in Roma communities, and mortality is high among young people, as mentioned above. 
Figure 24. Life style indicators
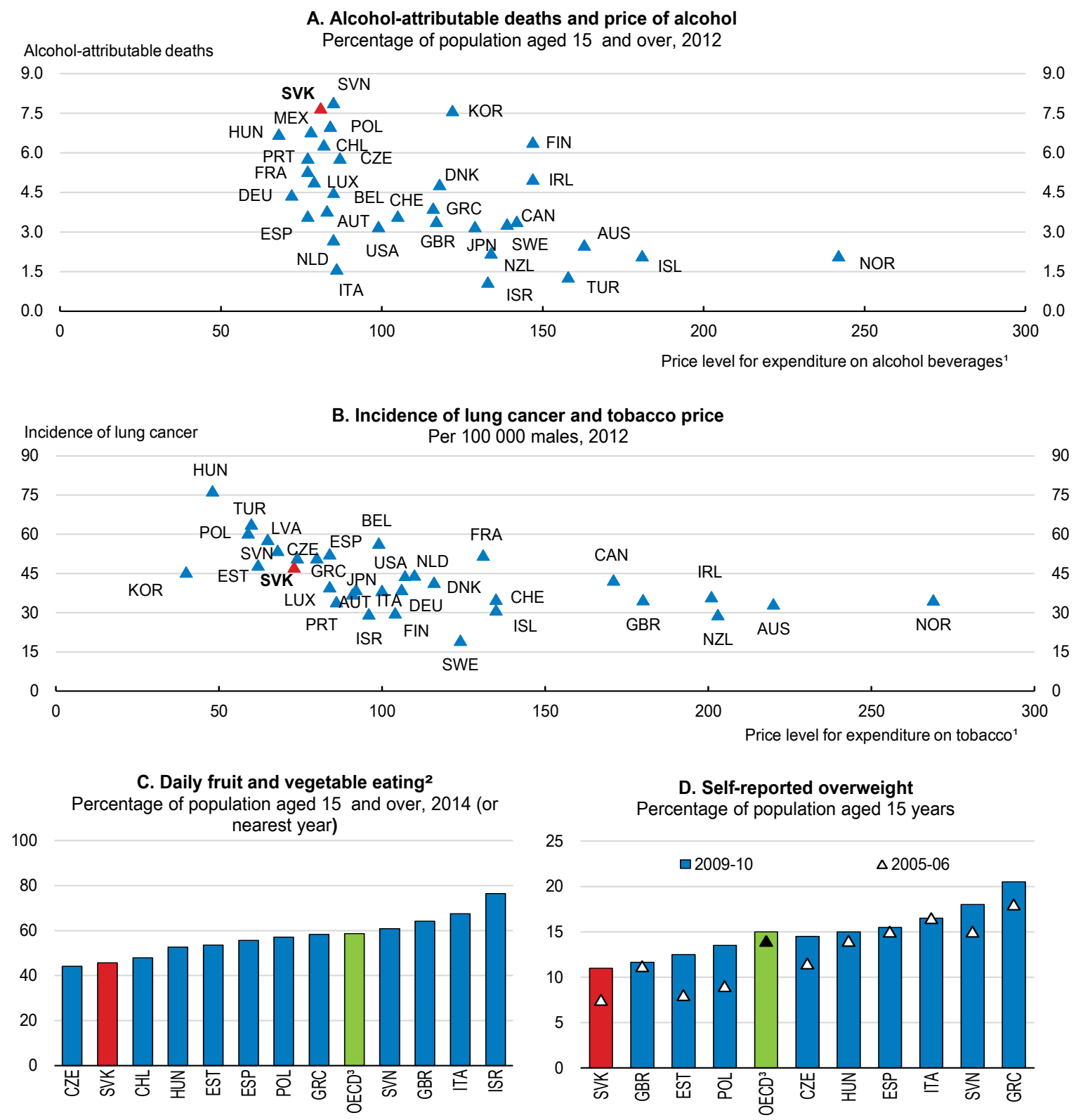

1. 2011 PPP benchmark results in US dollars. OECD $=100$.

2. Unweighted average of daily consumption of fruits and vegetables.

3. Unweighted average.

Source: OECD (2016), OECD Health Statistics (database), OECD (2015), Health at a Glance 2015: OECD Indicators, OECD (2016), Purchasing Power Parities (PPP) Statistics (database) and F. Sassi (ed.) (2015), Tackling Harmful Alcohol Use: Economics and Public Health Policy, OECD Publishing, Paris. 
Figure 25. Selected indicators of Roma versus non-Roma living conditions

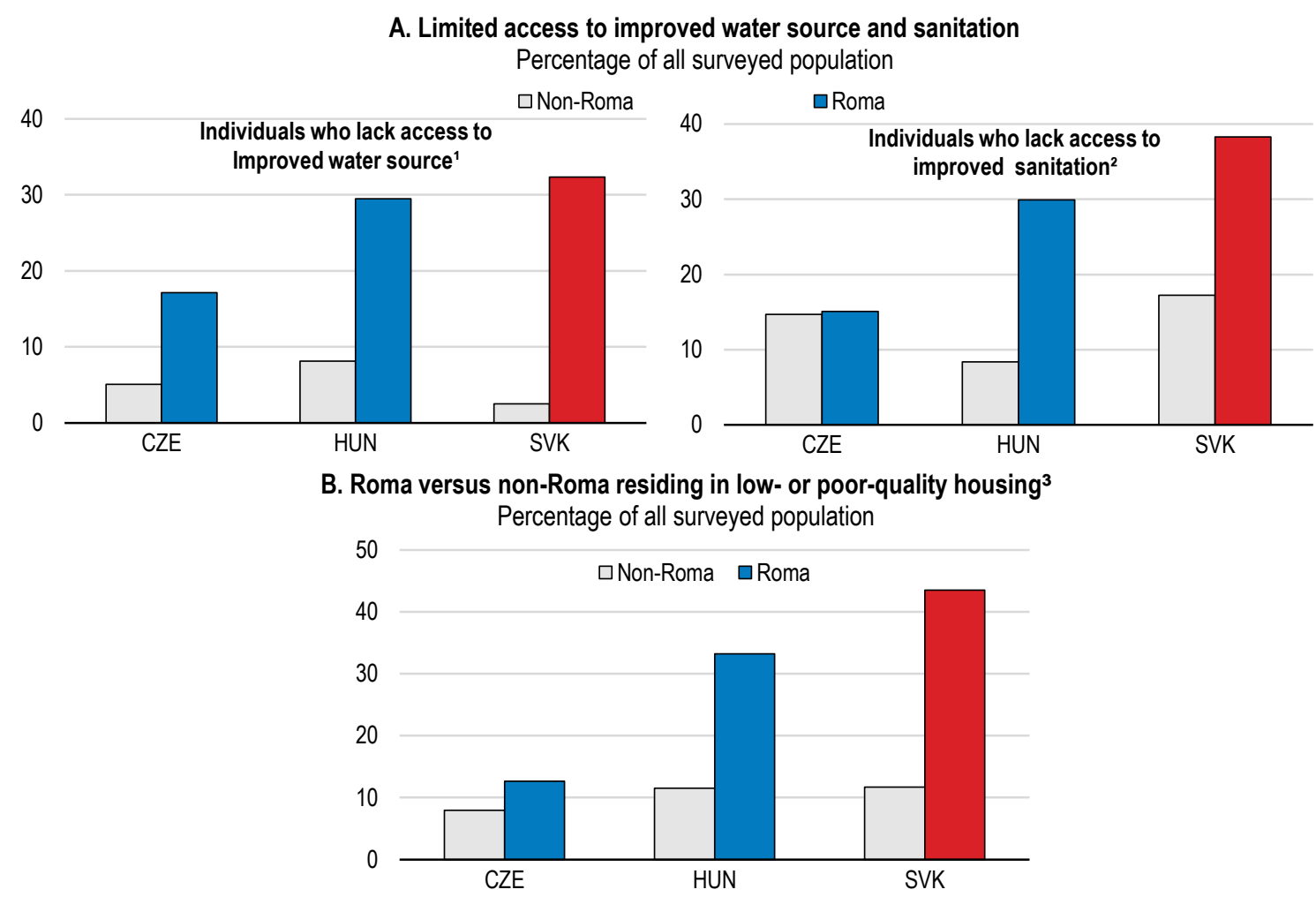

1. Having piped water inside the dwelling or in the garden/yard.

2. Having a toilet and a shower or bathroom inside the dwelling.

3. Living in ruined houses or slums.

Source: United Nations Development Programme (2016), Database on vulnerability of Roma based on UNDP/ WB/EC Regional Roma Survey 2011 and Pilot survey 2011 conducted by the EU Agency for Fundamental Rights (FRA).

Given this situation, encouraging the Roma communities to adopt healthier behaviour will take wideranging action specifically targeted at their needs. Working alongside NGOs, the authorities have taken some initiatives to raise awareness of the importance of hygiene and health and to improve their access to health-care providers. These initiatives include public information and education campaigns in the Roma language. Since 2014 they have also called on mediators from within these communities, trained by the Ministry of Health. At end-2015 there were some 250 mediators for 239 locations and a population of almost 68000 living in segregated areas. They help patients to manage their own health, encourage up-take of vaccinations and contribute to the prevention of infectious diseases by accompanying them to the doctor, interpreting if necessary and helping them to appreciate the importance of their medical treatments.

These measures are a step in the right direction, and they seem to be bearing fruit. The direct involvement of Roma mediators in these initiatives matters, because they are better able to target the needs of the community and increase its sense of ownership and empowerment in community health and wellbeing. While it is still too early to measure the outcomes in terms of people's health, the additional resources and staff that the authorities seem to be prepared to make available will certainly be useful, given the size of the challenge. The authorities could also deploy mobile medical units for regular visits to remote communities, with financial incentives for the providers offering these services. As a general principle, the authorities should seek, as much as possible, to involve the Roma community in other 
initiatives to improve their health outcomes, such as the development of water treatment, infrastructure access and improved housing. Such involvement would help to ensure that the new infrastructure and services meet the needs of Roma communities, by avoiding the obstacles that might restrict their use, such as financial impediments or excessive costs, and by informing Roma people of the advantages attached to them (Gatti et al., 2016).

\section{Recommendations to improve the health-care system \\ (Key recommendations included in the Executive Summary are in bold italics)}

Modernise hospital management and services

- Further centralise hospital procurement, professionalise their management and decouple salaries from national average wage.

- Further cut the number of acute-care beds.

- Phase in the diagnosis-related-group-based hospital financing system.

- Closely monitor the implementation of this new financing system, and plan audits to ensure diagnosis related groups are correctly coded and priced, setting adequate penalties in case of fraud.

- Rationalise the geographical distribution and the specialisation of care in the hospital network.

- Promote the management skills of heads of hospital departments.

- Seriously consider improving nurses' pay and working conditions.

- Introduce performance-related pay for hospital doctors.

Improve the efficiency and quality of primary health care

- Further increase medical school places for general practitioners, and expand their prescription-writing authority.

- Expand fee-for-service payments for primary care procedures of general practitioners.

- Consider introducing an adjustable price system for specialists' fee-for-service payment with a capped budget, as in Germany.

- Restrict authorisation for doctors wishing to set up a private practice in well served areas, and introduce financial incentives for them to move to poorly served areas.

- Improve the coordination of services between providers, including through the development of poly-clinics and a more rapid implementation of electronic personal health records.

- Promote better management of queues in out-patient services by encouraging all doctors to implement an appointment system.

Pursue efforts to bring down pharmaceutical expenditure and other ancillary health-care spending

- Implement e-health and e-prescription programmes.

- Develop information campaigns to change doctors' behaviour and patients' expectations regarding drug prescriptions to cut the volume of pharmaceutical spending.

- Thoroughly check laboratory tests and ambulance services spending. Consider lowering prices in these fields.

- Investigate lobbying activities by pharmaceutical firms and testing labs, and improve transparency of their corporate tax data. Consider banning all "gifts" from pharmaceutical firms and testing labs to doctors.

\section{Develop a long-term care strategy}

- Create regional one-stop shops with well-trained personnel to coordinate and simplify access to long-term care services.

- Consider a regulated opening of the long-term care market to qualified foreign workers. 


\section{Promote healthier lifestyles}

- Promote Roma access to health care by increasing support for trained Roma mediator programmes.

- Increase excises on alcohol and tobacco, engaging in discussion with other central European countries to harmonise the taxation of these products. Consider introducing specific levies on sweetened beverages.

- Deploy mobile medical units for regular visits to segregated Roma communities, with financial incentives for the providers offering these services.

\section{REFERENCES}

Adamovsky, P. (2016a), "Health Minister pushed private pharmacies from hospitals", published in the Slovak Spectator on 16 June, http://spectator.sme.sk/c/20192536/health-minister-pushes-private-pharmacies-from-hospitals.html

Adamovsky, P. (2016b), "Health Ministry to ban re-export of medicine", published in the Slovak Spectator on 13 July, http://spectator.sme.sk/c/20212765/health-ministry-to-ban-reexport-of-medicine.html

Adamovsky, P. (2016c), "Licensing of prescription drugs flawed", published in the Slovak Spectator on 1 September, http://spectator.sme.sk/c/20259158/licensing-of-prescription-drugs-flawed.html

Annear, P. and D. Huntington (eds.) (2015), "Case-based payment systems for hospital funding in Asia: an investigation of current status and future directions", Asia Pacific Observatory on Health Systems and Policies and OECD.

http://www.oecd.org/health/health-systems/case-based-payment-systems-for-hospital-funding-inasia-9789290617327-en.htm

Belloni, A., D. Morgan and V. Paris (2016), "Pharmaceutical Expenditure and Policies: Past Trends and Future Challenges", OECD Health Working Papers, No. 87, OECD Publishing, Paris. http://dx.doi.org/10.1787/5jm0q1f4cdq7-en

Cashin, C., Y-L. Chi, P. Smith, M. Borowitz and S.Thomson (2014), Paying for performance in health care. Implications for health system performance and accountability, European Observatory on Health Systems and Policies Series, Open University Press.

http://www.euro.who.int/en/about-us/partners/observatory/publications/studies/paying-forperformance-in-health-care.-implications-for-health-system-performance-and-accountability

Colombo, F. and N. Tapay (2004), "The Slovak health insurance system and the potential role for private health insurance: Policy challenges", OECD Health Working Papers, No. 11, OECD Publishing, Paris.

http://www.oecd.org/health/health-systems/29878719.pdf

de la Maisonneuve, C. and J. Oliveira Martins (2013), "A Projection Method for Public Health and LongTerm Care Expenditures", OECD Economics Department Working Papers, No. 1048, OECD Publishing,

Paris. http://www.oecd.org/officialdocuments/publicdisplaydocumentpdf/?cote=ECO/WKP(2013)40\&doc Language $=$ En 
de la Maisonneuve, C., R. Moreno-Serra, F. Murtin and J. Oliveira Martins (2016), "The drivers of public health spending: Integrating policies and institutions", OECD Economics Department Working Papers, No. 1283, OECD Publishing, Paris. http://dx.doi.org/10.1787/5jm2f76rnhkj-en

Dovera (2016), "Prehl'ad čakacích lehôt" (Summary waiting times), February, http://www.dovera.sk/cakacie-listiny

Dutu, R. and P. Sicari (2016) "Public Spending Efficiency in the OECD: Benchmarking Health Care, Education and General Administration", OECD Economics Department Working Papers, No 1278, OECD Publishing, Paris. http://dx.doi.org/10.1787/5jm3st732jnq-en

European Commission (EC) (2013), "Study on Corruption in the Health Care Sector", Country report on Slovakia. http://ec.europa.eu/dgs/home-affairs/what-isnew/news/news/docs/20131219 study on corruption in the healthcare sector en.pdf

EC (2015a), "Comparative efficiency of health systems, corrected for selected lifestyle factors", final report

MACELI, http://ec.europa.eu/health/systems_performance_assessment/docs/2015_maceli_report_en.pdf

EC (2015b), "The 2015 Ageing Report. Economic and budgetary projections for the 28 EU Member States (2013-2060)", European Economy, No. 3/2015. http://europa.eu/epc/pdf/ageing_report_2015_en.pdf

Economist (2014), "Still Protesting after all these years", 21 November, http://www.economist.com/news/europe/21634255-two-halves-former-czechoslovakia-are-bothangry-their-political-establishments-still

Economist (2015), "Patients Bearing Gifts", 24 March, http://www.economist.com/news/europe/21647087-central-and-eastern-europe-low-paid-doctorsaccept-bribes-and-patients-offer-them-patients-bearing

Filko, M., J. Mach and M. Zajíček (2012), "Málo zdravia za vel’a peňazí: Analýza efektívnosti slovenského zdravotníctva" ("Not enough health for a lot of money: Analysis of expenditure efficiency of the Slovak Health Care System"), Institute of Financial Policy. http://hpi.sk/cdata/Documents/IFP EA28 Efektivnost.pdf

Gatti, R., S. Karacsony, K. Anan, C. Ferré, and C. de Paz Nieves (2016), Being Fair, Faring Better. Promoting Equality of Opportunity for Marginalized Roma, World Bank Group, Human Development, http://wwwwds.worldbank.org/external/default/WDSContentServer/WDSP/IB/2016/01/27/090224b084103a5f/ 2_0/Rendered/PDF/Being0fair00fa0or0marginalized0Roma.pdf

Gavurová, B., V. Šoltés, and M. Šoltés (2014), "Meranie zdravia a zdravotných rizík vo vybraných rómskych osadách na Slovensku - fakty a reflexive" ("Measuring health and health risks in the chosen Roma settlements in Slovakia - facts and reflections"), in Nerovnost' a chudoba v Európskej únii a na Slovensku, 22-24 October, Košice. 
Hadad, S., Y. Hadad and T. Simon-Tuval (2013), "Determinants of healthcare system's efficiency in OECD countries", European Journal of Health Economics, Vol.14, No. 2.

Hüfner, F. (2011), "Increasing Public Sector Efficiency in Slovakia", OECD Economics Department Working Papers, No. 839, OECD Publishing, Paris.

http://dx.doi.org/10.1787/5kgj310m0q0r-en

Ineko (2012a), "O častých výmenách riaditel’ov štátnych nemocníc" ("The frequent changes of directors of public hospitals, July 2,

http://www.i-health.sk/inekomentare/1160 inekomentare-o-castych-vymenach-riaditelov-statnych$\underline{\text { nemocnic }}$

Ineko (2012b), "Assessment of the public procurement of hospitals in 2009-2012: Intensity of the competition for tenders is low", Zachar, D and Z. Dančíková, August.

Ineko (2015), "Ako Slovensko Zaplatí za neliečenie zdravotníctva" ("How Slovakia will pay for not treating its Healthcare: Analysis of population's health status, factors affecting it and long term prospects of Slovak healthcare financial sustainability"), June.

Kiss, S. (2007), Equity in Health Care Finance in Slovakia - the Impact of the Reform, Erasmus University, Rotterdam.

http://static.etrend.sk/uploads/tx media/blogy/169/STEFAN-KISS-EQUITY-IN-HEALTH-CAREFINANCE-THESIS-FINAL.pdf

Kossarova, L., W. Holland and E. Mossialos (2012), "Avoidable' mortality: A measure of health system performance in the Czech Republic and Slovakia between 1971 and 2008", Health Policy and Planning.

Lichtenberg, F. (2007), "Benefits and Costs of Newer Drugs: An Update", Columbia University and National Bureau of Economic Research Manage, published online in Wiley InterScience, http://onlinelibrary.wiley.com/doi/10.1002/mde.1355/epdf

Marron, D., M. Gearing and J. Iselin (2015) "Should we tax unhealthy foods and drinks?", UrbanBrookings Tax Policy Centre Working Paper, December, http://www.taxpolicycenter.org/sites/default/files/alfresco/publication-pdfs/2000553-Should-WeTax-Unhealthy-Foods-and-Drinks.pdf

Medeiros, J. and C. Schwierz (2015), "European economy: Efficiency estimates of health care systems", $\begin{array}{llll}\text { European Commission, } & \text { Economic }\end{array}$ http://ec.europa.eu/economy_finance/publications/

Ministry of Health (MOH) (2013), "Strategic framework for health for 2014-2030", http://www.health.gov.sk/?Key-publications

Ministry of Finance (MOF) (2015), "National Reform Programme of the Slovak Republic 2015", April, http://ec.europa.eu/europe2020/pdf/csr2015/nrp2015 slovakia en.pdf

Muzik, R. and A. Szalayova (2013), Analyza neformalnych platieb v zdravotnictve na Slovensku, ("Analysis of informal payments in healthcare in Slovakia"), Health Policy Institute, http://www.hpi.sk/cdata/Publications/Analyza_neformalnych_platieb_2013.pdf 
Nádaždyová, M., L. Brichtová, S. Mesároš, M. Laktišová and K. Repková (2013), "Filling the gap in longterm professional care through systematic migration policies: In search for win-win solutions in the LTC sector making use of managed migration", Comments paper - Slovak Republic, Germany, 2324 October.

O’Donnell, C. (2000), "Variation in GP referral rates: what can we learn from the literature?", Family Practice, Oxford University Press, Vol 17 No 6.

https://academic.oup.com/fampra/article/17/6/462/507355/Variation-in-GP-referral-rates-what-canwe-learn

OECD (2010), Health Care Systems: Efficiency and Policy Settings, OECD Publishing, Paris. http://dx.doi.org/10.1787/9789264094901-en

OECD (2014), OECD Economic Surveys: Slovak Republic 2014, OECD Publishing, Paris. http://dx.doi.org/10.1787/eco surveys-svk-2014

OECD (2015a), "Inclusive Growth and Health", Note by the Directorate for Employment, Labour and Social Affairs for the Health Committee, DELSA/HEA(2015)14, 16 November.

OECD (2015b), "Pharmaceutical spending trends and future challenges", Health at a Glance 2015: OECD Indicators, OECD Publishing, Paris.

http://dx.doi.org/10.1787/health glance-2015-en

OECD (2015c), Tackling Harmful Alcohol Use: Economics and Public Health Policy, OECD Publishing, Paris.

http://dx.doi.org/10.1787/9789264181069-en

OECD (2016a), Innovation in provider payment: New levers to drive health system performance, OECD Publishing, Paris.

OECD (2016b), Health Workforce Policies in OECD Countries: Right Jobs, Right Skills, Right Places, OECD Health Policy Studies, OECD Publishing, Paris. http://dx.doi.org/10.1787/9789264239517-en

OECD (2017a), Tackling Wasteful Spending on Health, OECD Publishing, Paris. http://dx.doi.org/10.1787/9789264266414-en

OECD (2017b), New Health Technologies: Managing Access, Value and Sustainability, OECD Publishing, Paris.

http://dx.doi.org/10.1787/9789264266438-en

OECD (2017c), OECD Economic Surveys: Slovak Republic, OECD Publishing, Paris.

Pažitný, P., T. Szalay, A. Szalayová, K. Morvay, R. Mužik, M. Pourová, D. Kandilaki, P. Balík and T. Sivák (2014), "Modernization of Slovak Hospitals, Basic Frameworks of Health Care Policy 20142016", Health Policy Institute.

http://hpi.sk/cdata/Publications/hpi_zakladne_ramce_2014.pdf

Poprocký, I. (2010), "Infraštruktúra slovenských nemocníc", Zdravotná Politika, Vol. 5, No. 2-4. http://www.hpi.sk/cdata/IntoBalance/zdravotna politika 09-2010.pdf 
Ringberg, U., N. Fleten, T. Deraas, T. Hasvold and O. Førde (2013), "High referral rates to secondary care by general practitioners in Norway are associated with GPs' gender and specialist qualifications in family medicine, a study of 4350 consultations", BMC Health Services Research, Vol. 13, No. 147. http://bmchealthservres.biomedcentral.com/articles/10.1186/1472-6963-13-147

Sassi, F., A. Belloni and C. Capobianco (2013), "The Role of Fiscal Policies in Health Promotion", OECD Health Working Papers, No. 66, OECD Publishing, Paris.

http://dx.doi.org/10.1787/5k3twr94kvzx-en

Shah, J., A. Couffinhal, H. Nguyen, G. Schieber, D. Prokopov, S. Nenkov and P. Atanasov (2015), Final action plan for the implementation of DRG-based payments, World Bank Group, Washington, D.C. http://documents.worldbank.org/curated/en/2015/11/25465748/final-action-plan-implementationdrgs-based-payments

Šoltés, V., M. Šoltés and B. Gavurová (2014), "Vývoj mortality v regiónoch s vysokou koncentráciou rómskeho obyvatel'stva" ("Mortality development in the regions of high concentration of Roma population”), in Nerovnost' a chudoba v Európskej únii a na Slovensku, 22-24 October, Košice.

Spectator (2016a), "Health care in Slovakia deteriorates", Press article, 27 January, http://spectator.sme.sk/c/20080934/health-care-in-slovakia-deteriorates.html

Spectator (2016b), "Health-care system already lacks around 12000 nurses", Press article, 25 July, http://spectator.sme.sk/c/20223270/health-care-system-already-lacks-around-12000-nurses.html

Spectator (2016c), "New 'Ministerial Nurse' to lead nursing as August", Press article, 27 July, http://spectator.sme.sk/c/20225121/new-ministerial-nurse-to-lead-nursing-as-of-august.html

Spectator (2016d), "Parliament limits export of medicines", Press article, 19 October, http://spectator.sme.sk/c/20361686/parliament-limits-export-of-medicines.html

Spectator (2017), "Doctor's appointments possible from 2018", Press article, 1 February, https://spectator.sme.sk/c/20448885/doctors-appointments-possible-from-2018.html

Sprocha, B. (2014), Reprodukcia rómskeho obyvatel’stva na Slovensku a prognóza jeho populačného vývoja, INFOSTAT - Výskumné demografické centrum.

Šterbová, K. (2015), “Čo zastaví reexport? Poradit' si nevie ani Európska únia" (“What will stop re-export? Even the EU has no solution"), Hospodárske Noviny.

http://www.adl.sk/Media/Napisali-o-nas/Co-zastavi-reexport-Poradit-si-nevie-ani-Europska-unia/

Struijs, J. and C. Baan (2011) "Integrating care through bundled payments - lessons from the Netherlands", New England Journal of Medicine, Vol. 364, No.11, pp. 990-1. http://www.nejm.org/doi/pdf/10.1056/NEJMp1011849

Struijs, J., S. Mohnen, C. Molema, J. de Jong-van Til and C. Baan (2012), "Effects of bundled payment on curative health care costs in the Netherlands: An analysis of diabetes care and vascular risk management based on nationwide claim data", National Institute for Public Health and the Environment,

Bilthoven. http://www.rivm.nl/dsresource?objectid=rivmp:188652\&type=org\&disposition=inline\&ns_nc=1 
Szalay, T. (2011), Slovakia: Health System Review 2011, Health Systems in Transition, Vol. 13, No. 2, European Observatory on Health Systems and Policies, Copenhagen. http://www.euro.who.int/_data/assets/pdf_file/0004/140593/e94972.pdf

Szalayová A., K. Skybová, D. Kandilaki and T. Szalay (2014),”Analýza lekárenského trhu na Slovensku a v Českej republike: Vývoj za posledných 10 rokov" ("Analysis of the pharmaceutical market in Slovakia and in Czech Republic: Evolution over the past 10 years"), Health Policy Institute. http://www.hpi.sk/cdata/Publications/hpi analyza lekarenskeho trhu.pdf

Tunega, M (2013), "Širší pohl'ad na efektívnost' slovenského zdravotníctva: Viaceré pohl'ady na dostupné štatistické údaje z oblasti zdravotníctva v SR a v porovnatel'ných krajinách" ("A broader view of the effectiveness of Slovak health care: Several views of the statistical data available from the health sector in Slovakia and in comparable countries"), INEKO.

Transparency International Slovakia (2014) "Lekári prestali spolupracovat' s farmabiznisom. Naozaj?" ("Doctors stopped cooperating with pharmaceutical companies. Really?"). http://www.transparency.sk/sk/lekari-prestali-spolupracovat-s-farmabiznisom-naozaj/

Transparency International, (2015), "Základné výsledky (zdravotníctvo)" [Key results (for healthcare)]. http://www.transparency.sk/wpcontent/uploads/2015/02/Zakladne_vysledky_feb2015_zdravotnictvo.pdf

Vagač, L., P. Goliaš and D. Zachar (2012), "Country Document Update 2012: Pensions, health and longterm care, Slovakia, March 2012”, European Commission, Brussels.

Vagač, L., P. Goliaš, and D. Zachar (2014), "Country Document Update 2014: Pensions, health and longterm care, Slovakia, March 2014”, European Commission, Brussels.

WHO (2015), "Using price policies to promote healthier diets", World Health Organization, Geneva http://www.euro.who.int/ data/assets/pdf file/0008/273662/Using-price-policies-to-promotehealthier-diets.pdf

WHO (2016), Health system in transition - Slovakia: Health system review, European Observatory on Health Systems and Policies.

Zachar, D. (2013), “Zdravotnícky system v SR (2012-2013)” (“Slovak Health Care System (2012-2013)”), INEKO.

Zachar, D. and Z. Dančíková (2014), "Vo vel'kých nemocničných tendroch sa sútaží málo: Analýza verejného obstarávania nemocníc v rokoch 2012-2014)", ("Little competition in large hospital tenders: Analysis of public procurement in Slovak hospitals, 2012-2014”), INEKO, Transparency International Slovakia. 
APPENDIX A1.

Health outcome performance ${ }^{1}$

\begin{tabular}{|c|c|c|c|c|c|c|c|}
\hline & $\begin{array}{c}\text { Life } \\
\text { expectancy } \\
\text { at birth, total } \\
\text { population }\end{array}$ & $\begin{array}{c}\text { Life } \\
\text { expectancy, } \\
\text { Male at } 65, \\
\text { total } \\
\text { population } \\
\end{array}$ & $\begin{array}{c}\text { Life } \\
\text { expectancy, } \\
\text { Female at } 65, \\
\text { total } \\
\text { population }\end{array}$ & $\begin{array}{l}\text { Mortality rate, } \\
\text { all causes }\end{array}$ & $\begin{array}{c}\text { Infant } \\
\text { mortality rate }\end{array}$ & $\begin{array}{l}\text { Premature } \\
\text { mortality }\end{array}$ & Average \\
\hline Australia & -0.1 & -0.4 & 0.3 & 0.2 & -0.2 & 0.3 & 0.0 \\
\hline Austria & -0.6 & -0.1 & -0.1 & 0.1 & -0.1 & 0.2 & -0.1 \\
\hline Belgium & -0.7 & -0.7 & 0.1 & -1.1 & 0.1 & -0.5 & -0.5 \\
\hline Canada & 0.3 & 0.2 & 0.0 & 1.0 & -1.5 & -0.4 & -0.1 \\
\hline Chile & 0.6 & 1.1 & 0.4 & 1.6 & -0.8 & 0.7 & 0.6 \\
\hline Czech Republic & -0.4 & -0.7 & -1.0 & -0.8 & 0.9 & 0.6 & -0.2 \\
\hline Denmark & -0.8 & -0.8 & -1.2 & -1.3 & -0.3 & -0.3 & -0.8 \\
\hline Estonia & -0.6 & -0.9 & 0.3 & -0.2 & 0.9 & -1.0 & -0.2 \\
\hline Finland & 0.9 & 0.7 & 0.3 & 1.0 & 1.1 & -0.3 & 0.6 \\
\hline France & 0.8 & 1.4 & 2.2 & 1.5 & 0.1 & 0.1 & 1.0 \\
\hline Germany & -0.4 & 0.1 & -0.4 & 0.0 & -0.3 & 0.0 & -0.2 \\
\hline Greece & 1.3 & 2.0 & 1.2 & 1.0 & 0.9 & 1.4 & 1.3 \\
\hline Hungary & -1.7 & -1.6 & -1.5 & -1.8 & -0.5 & -0.9 & -1.3 \\
\hline Iceland & 1.4 & 1.1 & 0.1 & 0.2 & 2.1 & 0.7 & 0.9 \\
\hline Ireland & -0.8 & -0.8 & -0.7 & -1.0 & -0.1 & -0.1 & -0.6 \\
\hline Israel & 1.6 & 1.9 & 0.5 & 1.8 & 0.2 & 0.5 & 1.1 \\
\hline Italy & 0.9 & 0.2 & 1.4 & 0.3 & 1.5 & 1.2 & 0.9 \\
\hline Korea & 0.7 & 0.1 & 1.3 & 0.8 & 0.5 & 0.8 & 0.7 \\
\hline Mexico & -0.5 & 0.3 & -0.4 & -1.1 & -0.9 & -1.7 & -0.7 \\
\hline Netherlands & 0.0 & 0.0 & -0.6 & 0.1 & -0.3 & 0.1 & -0.1 \\
\hline New Zealand & 0.6 & 0.7 & 0.4 & 0.3 & -0.8 & 0.2 & 0.2 \\
\hline Norway & -0.2 & -0.8 & -0.7 & -0.7 & 0.6 & -0.5 & -0.4 \\
\hline Poland & -0.3 & -0.1 & 0.2 & -0.1 & -0.5 & -0.5 & -0.2 \\
\hline Slovak Republic & -1.1 & -1.3 & -1.6 & -1.2 & -1.3 & -0.8 & -1.2 \\
\hline Slovenia & 1.3 & 0.8 & 0.9 & 0.6 & 1.2 & 0.9 & 1.0 \\
\hline Spain & 1.4 & 1.0 & 2.2 & 1.4 & 1.5 & 2.1 & 1.6 \\
\hline Sweden & 0.8 & 0.2 & -0.3 & 0.2 & 0.7 & 0.7 & 0.4 \\
\hline Switzerland & -0.3 & 0.0 & 0.2 & 0.4 & -1.0 & 0.3 & -0.1 \\
\hline Turkey & -1.4 & -2.2 & -1.5 & -0.5 & -0.6 & -0.4 & -1.1 \\
\hline United Kingdom & -0.4 & 0.0 & -0.2 & -0.7 & -0.5 & 0.2 & -0.3 \\
\hline United States & -2.5 & -1.5 & -1.6 & -1.9 & -2.4 & -3.5 & -2.2 \\
\hline Adjusted $\mathrm{R}^{2}$ & 0.59 & 0.61 & 0.41 & 0.58 & 0.41 & 0.57 & - \\
\hline
\end{tabular}

Note: This performance indicator is based on the estimation of regression residuals explaining the health system outcomes of 31 OECD countries evaluated by 6 different criteria by their per capita GDP and explanatory variables capturing lifestyle and/or social factors. These 6 criteria are those of the columns in the table above. For each criterion, the performance indicator is calculated as the residual of the corresponding regression divided by the standard deviation of the residuals. By construction, the average of each indicator across the sample of OECD countries is equal to 0 . A negative residual indicates a below OECD average performance in terms of efficiency of health outcomes for the corresponding criterion analysed. For example, for the life expectancy at birth, the residual for Slovakia is 1.1 time the standard deviations of the residuals for the 31 OECD countries, controlling for GDP per capita and other explanatory variables.

1. A regression is run for each criterion (in logs; for mortality variables, minus log is used) with one or more explanatory variables (in logs) and a constant on the right hand side. The five candidate explanatory variables are: GDP per capita in PPP terms (GDP); share of the population aged 15+ who are daily smokers (DAYSMOK); alcohol consumption in litre per capita for the population aged 15+ (DRINK); share of the population aged 25 to 64 with at least upper secondary education (EDU); and share of the population aged 15+ for daily consumption of fruits and vegetables (DIETCON). Considering which explanatory variables are statistically significant at the $1 \%\left(^{*}\right), 5 \%\left(^{* *}\right)$ and $10 \%\left(^{* * *}\right)$ for each indicator, explanatory variables are chosen as: GDP*, DAYSMOK ${ }^{* * *}$, DEU ${ }^{* * *}$ and DIETCON for life expectancy at birth; GDP*, EDU* and DIETCON ${ }^{* *}$ for life expectancy at 65 for male; GDP* for life expectancy at 65 for female; GDP*, EDU* and DIETCON** for

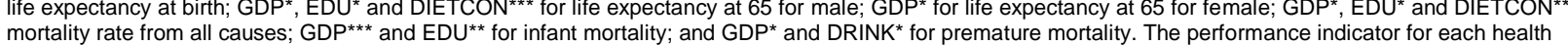
outcome criterion is calculated as the residual of the corresponding regression divided by the standard deviation of the residuals. The "Adjusted $\mathrm{R}^{2}$ " row corresponds to the adjusted $\mathrm{R}^{2}$ of that regression.

Source: OECD calculations based on OECD (2016), OECD Health Statistics (database). 